\title{
ASPECTOS GEOMORFOLÓGICOS E GEOESPELEOLOGIA DO CARSTE DA REGIÃO DE IRAQUARA, CENTRO-NORTE DA CHAPADA DIAMANTINA, ESTADO DA BAHIA
}

FRANCISCO WILLIAM DA CRUZ JUNIOR

Orientador: Prof. Dr. Ivo Karmann

DISSERTAÇÃO DE MESTRADO

COMISSÃO JULGADORA

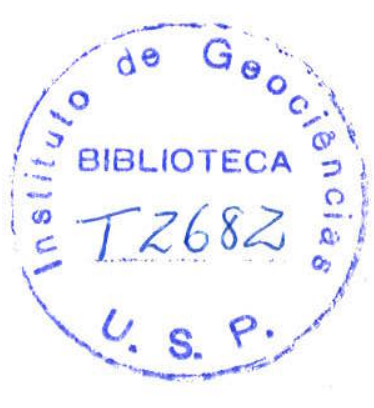

Nome

Presidente: Prof. Dr. Ivo Karmann

Examinadores: Prof. Dr. Benjamim Bley de B. Neves Prof. Dr. Luís B. Piló

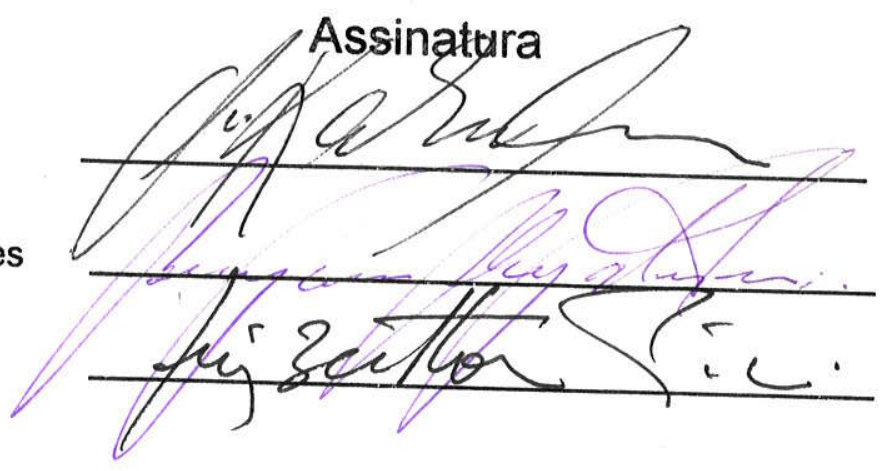

SÃO PAULO

1998 


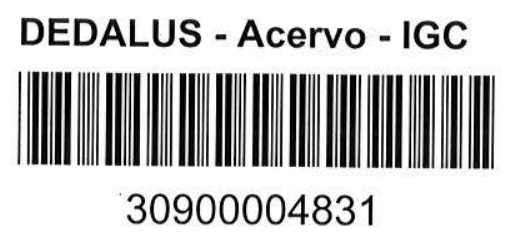

DISSERTAÇÃO DE MESTRADO

Francisco William da Cruz Júnior

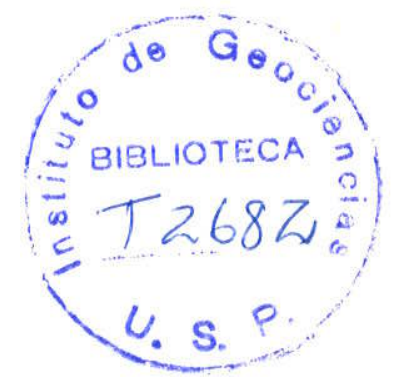

Orientador: Prof. Dr. Ivo Karmann

Programa de Pós-Graduação em Geoquímica e Geotectônica

São Paulo

1998 


\section{SUMÁRIO}

ÍNDICE DE FIGURAS

ÍNDICE DE TABELAS VII

ÍNDICE DE ANEXOS VIII

RESUMO IX IX IX

ABSTRAC'T XI

AGRADECIMENTOS XIII

$\begin{array}{ll}1 \text { - INTROIDUÇ̃̃̃O } & 01\end{array}$

1.1 - Apresentação do tema de trabalho 01

1.2 - Localização e seleção da área de pesquisa $\quad 02$

1.3 - Objetivos da pesquisa 04

1.4 - Metodologia de trabalho 05

2 - ASPECTIOS AMBIENTAIS DA ÁREA HM HESTUDO 07

2.1 - Contexto geológico 07

2.1.1 - A Bacia de Irecê e as rochas carbonáticas 07

2.1.2 - Situação tectônica e geologia estrutural 09

$\begin{array}{ll}2.2 \text { - Situação geomorfológica } & 10\end{array}$

2.3 - Distribuição de sistemas de cavernas e direção geral de fluxo hidrológico 13

$\begin{array}{ll}2.4 \text { - Vegetação } & 19\end{array}$

2.5 - Clima 20

3 - O CARSTE EM SUPERFÍCIE: 21

3.1 - Arcabouço geológico e aspectos da morfologia cárstica 21

3.2 - Tipos e distribuição de feições do relevo 26

3.3 - Morfometria de feições cársticas 31

4 - CARACTERIZAÇÃO MORFOLÓGICA, GHOLÓGICA E PALEOHIDROGRÁFICA DOS SISTEMAS

LAPA DOCE E LAPA DA TORRINHA 44

4.1 - Introdução 44

4.2 - Setores de cavernas mapeados 50

4.2.1 - Setores mapeados no Sistema Lapa Doce $\quad 50$

4.2.2 - Setores mapeados no Sistema Lapa da Torrinha 65

4.3 - Síntese da morfologia, condicionamento estrutural, paleofluxo e preenchimento sedimentar 


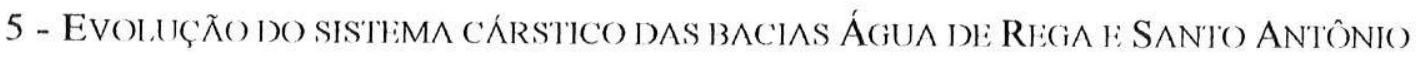

5.1 - Condicionamento hidrológico e geológico do desenvolvimento dos condutos 5.2 - A evolução morfológica de condutos

5.3 - Correlação entre as feições cársticas superficiais e subterrânias 98

6 - CONCLUSÕES E RECOMENDAÇÕES 102

7 - REFERÊNCIAS BIBLIOGRÁFICAS 104 
Figura 1.1 - Mapa de localização da área estudada

Figura 2.1 - Localização da área estudada no contexto das coberturas carbonáticas neoproterozóicas da região da Chapada Diamantina

Figura 2.2 - Esboço dos contrastes do relevo local: (A) Mapa hipsométrico; (B) Bloco diagrama com exagero vertical de aproximadamente $25 \mathrm{X}$.

Figura 2.3 - Mapa de distribuição de cavernas e surgências situadas nas porções centro e sul da área de estudo.

Figura 2.4 - Principais padrões morfológicos de cavernas da área em planta

Figura 2.5 - Mapa potenciométrico e sentidos de fluxo hipotéticos em relação as feições de relevo locais

Figura 3.1 - Mapa de contorno da espessura da cobertura detrítica

Figura 3.2 - (a) Mapa de fotolineamentos; (b) histograma de roseta da direção de fotolineamentos; (c) densidade de comprimento de fotolineamentos por malha $1 \times 1 \mathrm{Km}$.

Figura 3.3 - Depressão fechada com perfil escarpado, situada entre as cavernas Lapa Doce I e II, no Sistema Lapa Doce.

Figura 3.4 - Depressão fechada com perfil suave, situada na porção sul da área. $\quad 30$

Figura 3.5 - Setores da superfície carbonática considerados na análise morfométrica 33

Figura 3.6 - Gráfico de correlação entre área planimétrica das depressões fechadas 35

Figura 3.7 - Mapa de densidade de área de depressões fechadas em malha 1 x $1 \mathrm{~km} \quad 36$

Figura 3.8 - Orientação e comprimento de depressões fechadas 39

Figura 3.9 - Gráfico da relação alométrica entre o comprimento e largura do eixo maior de depressões fechadas

Figura 3.10 - Separação morfológica de depressões fechadas a partir do índice de circularidade

Figura 4.1 - Mapa do Sistema Lapa Doce 45

Figura 4.2 - Mapa do Sistema Lapa da Torrinha

Figura 4.3 - Esquema para orientação do sentido do fluxo através de marcas de correntes. 
Figura 4.4 - Exemplo de marcas de corrente assimétricas, medidas em paredes de condutos, setor 1 (Conduto da Pedra Furada)

Figura 4.5 - Condutos com morfologia de canyons com seções triangulares apresentando cúpulas de corrossão alinhadas concordantemente na direção da fraturas no teto, situado na porção norte do setor 1 (Conduto da Pedra Furada)

Figura 4.6 - Conduto com morfologia semi-elipsoidal com teto plano característico, Setor 3 (Minotauro).

Figura 4.7 - Conduto com morfologia em canyon situado em níveis inferiores do Setor 3 , drenado por cursos temporários de água, com marcas de nível de água.

Figura 4.8 - Salão a NE do Setor 3, caracterizado por pendants, pequenos canais e sedimento encrustados no teto.

Figura 4.9 - Trecho do conduto principal do Sistema Lapa Doce, apresentando morfologia elipsoidal, Setor 4, entrada do percurso turístico.

Figura 4.10 - Vista do patamar rochoso na entrada do Setor 5, Conduto do Hagar e do canal semi-elíptico no teto ao fundo.

Figura 4.11 - Escarpas em sedimentos e conjuntos de pendants e pilares com aspecto de karrens na junção entre condutos do Sistema Lapa da Torrinha.

Figura 4.12 - Conduto com morfologia elipsoidal e cúpulas de corrosão no teto, Setor 7 , Conduto do Chifre.

Figura 4.13 - Pendants e marcas de sedimento observados em condutos com morfologia elipsoidal, ponto de ramificação 4, Setor 8 , Conduto do Vermão.

Figura 4.14 - Canal de teto na galeria NE-SW, do segmento 2, Setor 8, Conduto do Vermão.

Figura 4.15 - Trancamento de condutos observados no ponto de ramificação R3,

Setor 8 , Conduto do Vermão.

Figura 4.16 - Conduto quase totalmente entupido por sedimentos clásticos, Setor 9 , Caótico.

Figura 4.17 - Vista do canal entalhado no piso de sedimento, crostas de sedimento e pendants junto ao teto do Salão do Vale, Setor 9.

Figura 4.18 - Capas estalagmíticas suspensas no Salão do Vale, Setor 9, indicativos de antigo nível de preenchimento sedimentar. 
Figura 4.19 - Conjunto de colunas, pilares e mesas com aspecto de karrens e escarpas de sedimento ao fundo, Setor 9, Caótico.

Figura 4.20 - Quadro resumido dos padrões morfológicos de condutos: (A) padrões em planta; (B) padrões em seção transversal

Figura 4.21 - Histogramas e diagramas de contorno de polos

Figura 4.22 - Fraturas de cisalhamento do tipo 1 86

Figura 4.23 - Fraturas de cisalhamento do tipo 2 86

Figura 4.24 - Paleorrotas de fluxo nos sistemas de cavernas estudados: (A) Sistema Lapa Doce; (B) Sistema Lapa da Torrinha

Figura 5.1 - Ilustração esquemática: evolução de condutos paragenéticos e singenéticos 94

Figura 5.2 - Quadro evolutivo em planta e perfil em junção de condutos situados no Setor 8, Sistema Lapa da Torrinha. 
Tabela 31. - Densidade de depressões cársticas 34

Tabela 3.2 - Área e perímetro das depressões fechadas 35

Tabela 3.3 - Razão de dolineamento e índice de dolineamento 37

Tabela 3.4 - Dados da orientação e comprimento do eixo maior de depressões medidos no Setor Sul da área $\quad 40$

Tabela 3.5 - Índice de circularidade $\quad 42$

Tabela 3.6 - Densidade de sumidouros autogênicos $\quad 42$

Tabela 4.1 - Atitudes predominantes de estruturas geológicas 83

Tabela 5.1 - Resumo das principais fases evolutivas dos sistemas de condutos estudados 92 
Anexo 1- Mapa de fenômenos cársticos. Região de Iraquara - BA Anexo 2 - Sistema Lapa Doce. Setor 1. Conduto da Pedra Furada Anexo 3 - Sistema Lapa Doce. Setor 2. Saída Turística Anexo 4 - Sistema Lapa Doce. Setor 3. Minotauro Anexo 5 - Sistema Lapa Doce. Setor 4. Entrada Turística Anexo 6 - Sistema Lapa Doce. Setor 5. Conduto do Hagar Anexo 7 - Sistema Lapa Doce. Setor 6. Conduto do Neguinho Anexo 8 - Sistema Lapa da Torrinha. Setor 7. Conduto do Chifre Anexo 9 - Sistema Lapa da Torrinha. Setor 8. Conduto do Vermão Anexo 10 - Sistema Lapa da Torrinha. Setor 9. Salão do Vale e Setor Caótico. 
Através de estudos morfológicos e geoespeleológicos são descritas as ocorrências de feições cársticas inseridas em rochas carbonáticas neoproterozóicas do Grupo Una. A área de trabalho localiza-se nas proximidades do Rio Santo Antônio, entre as cidades de Iraquara e Seabra, porção Centro-Norte da região da Chapada Diamantina, Estado da Bahia.

O relevo da área é caracterizado por um planalto cárstico com cotas variando entre $600 \mathrm{e}$ $800 \mathrm{~m}$ circundado por serras de rochas siliciclásticas que chegam a ultrapassar $1000 \mathrm{~m}$ de altitude. A drenagem é caracterizada na maior parte da área pela ausência de uma rede contínua e organizada de canais fluviais, principalmente sobre as rochas carbonáticas.

A partir do mapeamento geomorfológico com base em fotografias aéreas 1:25.000 tem-se a configuração da morfologia do relevo, com destaque para a presença de depressões fechadas, vales cársticos, poljes, surgências, vales secos e pontos e absorção do escoamento superficial.

As depressões fechadas são analisadas morfometricamente de forma que foi possível concluir um considerável grau de influência de condutos e estruturas geológicas, em diferentes setores da área, na distribuição, forma e tamanho de grupos de depressões. Os principais parâmetros utilizados para postular tais considerações são a densidade, orientação do eixo maior das depressões e razão entre sua largura e comprimento, área planimétrica e perímetro, índice de dolinamento, razão de dolinamento e índice de circularidade.

Os sistemas de cavernas Lapa Doce e Lapa da Torrinha tiveram sua iniciação associada a injeção mista com importante fração alogênica em relação a autogênica. Este fato é evidenciado pela superfície carbonática rebaixada em relação as rochas não carbonáticas e pela geometria dos vales cársticos e sua continuidade sobre as rochas não-carbonáticas.

O mapeamento morfológico, geoespeleológico e das paleorrotas de fluxo realizado em seis setores do Sistema Lapa Doce e três setores do Sistema Lapa da Torrinha, com o emprego de plantas, perfis longitudinais e seções transversais, resultou na identificação dos principais padrões morfológicos de condutos. A morfologia em planta associada às paleorrotas de fluxo indicam o padrão geral distributário com predomínio de condutos NW-SE e paleofluxo para SE. A recarga concentrou-se principalmente nas galerias principais, de onde formaram-se os ramos laterais de condutos em padrão distributário, alça, rede e anastomosados. Em seção transversal, predominam condutos com morfologia elipsoidal e em canyon, onde os processos de incasão pouco atuaram. 
A hipótese de condicionamento dos condutos por estruturas geológicas foi verificada a partir da comparação da direção entre os segmentos de passagens de cavernas e os traços de fraturas, que ocorrem preferencialmente nos intervalos N10-20W, N50-60W, N70-80W e N6070E no Sistema Lapa Doce e N10-20W, N40-50W e N70-90W no Sistema Lapa da Torrinha. Com base em histogramas e no teste de correlação estatística Kolgomorov-Smirnov obteve-se a correlação entre estes parâmetros em dois setores de cavernas. De modo geral, os sistemas acompanham a direção dos planos de acamamento e a direção inferida do gradiente hidráulico, sendo localmente condicionados por fraturas.

A análise morfológica dos condutos e do pacote de sedimentos clásticos que preencheram os condutos em quase toda a sua extensão sugere uma evolução multifásica para os sistemas de cavernas. A evolução é descrita em quatro fases correspondentes a abertura, ampliação, assoreamento e desobstrução de condutos. A fase de abertura inclui a iniciação e desenvolvimento freático de condutos; a fase de ampliação consiste no entalhamento normal de condutos por singênese; a fase de assoreamento é caracterizada por preenchimento sedimentar até o nível do teto dos condutos e modificação por paragênese; por fim, a fase de entupimento envolve a remoção do preenchimento sedimentar dos condutos, erosão das passagens de cavernas e abertura de passagens menores. 
Morphological and speleological investigations of Neoproterozoics carbonate rocks of the Una Group, led to the description of karstic features near to Santo Antônio River, between Iraquara and Seabra, center-northern Chapada Diamantina, State of Bahia, Brazil. Local relief is characterized by a karstic plateau between 600 and $800 \mathrm{~m}$ in altitude surrounded by terrigenous hills, some higher than $1000 \mathrm{~m}$, without a continuous and organized network of fluvial channels in most of the area.

Geomorphologic mapping based on aerial photographs (1:25.000) revealed closed depressions, poljes, surgences, dry valleys and sink streams as the main features of the landscapes.

Morphometric analysis of closed depressions utilizing such parameters as density, preferred main-axis orientation, width/length ratio, planimetric area and perimeter, index of pitting and index of circularity showed a considerable degree of influence of conduits and geologic structures in the distribution, form and size of the features in different parts of area.

Mixed injection with important contents of alogenic in relation to autogenic recharge is inferred to initiation phase of the Lapa Doce and Lapa da Torrinha cave systems based on the lowering of the surface of the carbonate with respect to non-carbonate rocks and on geometry of the karstic valley and their continuity in the non-carbonate rocks.

Morphological, geospeleological and paleoflow mapping in six sections of Lapa Doce and three sections of the Lapa da Torrinha system, using planimetric maps, longitudinal profiles and cross-sections resulted in the identification of the main cave patterns. The morphology in plan views associated with paleoflow routes indicates a distributary pattern for both caves having a prevalecence of NW-SE conduits and paleoflow towards the SE. Recharge was concentrated mainly in trunk galleries, from which lateral branches with distributary, bypass, network and anastomosed patterns developed. In cross-section where incasion processes are not too efective conduits prevail with elliptical and canyon morphology. 
The hyphothesis of conduits developing along geologic structures was verified by comparison of the trends between the cave segments and fractures, which are concentrated mainly in the N10-20W, N50-60W, N70-80W e N60-70E sectors in Lapa Doce system and in the N10-20W, N40-50W e N70-90 sectors in the Torrinha system. Based on histograms and Kolgomorov-Smirnov tests the correlation among these parameters was obtained in just two cave sections. In general, the systems accompany bedding-plane partings and the inferred direction of the hydraulic gradient and are also locally controlled by fractures.

Morphologic analysis of the conduits and clastic sediments that filled the conduits in almost the entire extension of the caves suggests evolution of the cave system in four phases: opening, enlargement, infilling and sediment erosion. The opening phase included phreatic initiation and development of conduits; the enlargement phase consisted of normal entrenchment of conduits; the infilling phase was characterized by sedimentary clogging of the conduits up to cave roofs and morphologic modifications by paragenesis; the sediment removal phase involve partial erosion of sediment and conduits and opening of new passages. 
Ao Prof. Dr. Ivo Karmann que divide comigo a elaboração deste trabalho, agradeço o apoio sempre prestado nas mais diversas situações, o respeito e a amizade.

Ao Dr. José Antônio Ferrari do Instituto Geológico-IG, pelo auxílio prestado no geoprocessamento das análises morfométricas que resultaram na maioria dos dados apresentados no capítulo 3.

Ao grupo do UPE, especialmente Leandro Dybal Bertoni, Danilo Allegrini, Gabriela B. Slavecs, Fábio Kok C. Geribello, entre outros integrantes, pela grande colaboração prestada no mapeamento, topografia e outros auxílios no trabalho de campo além da amizade e interesse pela Espeleologia.

A minha esposa Patricia Cristalli, pelo total apoio nos diferentes estágios do trabalho, também pelo carinho e compreensão de muitas horas.

Ao colega Fernando Verassani Laureano, companheiro de pós-graduação, de trabalho de campo e de importantes discussões.

Aos demais colegas que trabalham com geologia de terrenos cársticos, Ricardo G.F.A. Pereira, Soraya Ayub e Murilo Valle pelas eventuais discussões e favores prestados.

A Carlos Henrique Grohmann de Carvalho pelas horas dedicadas a confecção da parte gráfica dos mapas e demais figuras.

Ao colega Gelson Fambrini pela valiosa e criteriosa revisão de texto.

A Alexandre de Oliveira Lobo, não somente pela participação nos trabalhos de campo como também pelo auxílio prestado na elaboração de importantes mapas.

Ao Grupo Bambuí de Pesquisas Espeleológicas-GBPE, em especial ao Ezio Rubbioli, por ter colaborado com vários mapas e dados sobre as cavernas da região de Iraquara.

A Augusto Auler da University of Bristol pelo envio de artigos e discussões a respeito da evolução dos sistemas de cavernas estudados.

Aos estudantes de graduação da geologia da USP, Paulo Eduardo P. Marcondes, Sasha Tom Hart, Kiung Wook Kim, Rafael Hernandez Correa Silva pelo acompanhamento nos trabalhos de campo.

Aos pós-graduandos do IME-USP, Adriana Bruscato e Fábio Montesano pelo auxílio no tratamento de dados estatísticos.

Aos colegas de pós-graduação do Instituto de Geociências: Alexandre Magno Feitosa 
Cândida Barbosa do Nascimento, Marcelo Altafini, Jefferson Picanço, Mauro Geraldes, Fernando Machado de Mello, Vânia Rosolen, ao casal Silvio Hiruma e Miriam, Rosely Imbernon, Anísia Pereira de Castro, Ana Lúcia Berretta, Laure Duvallet, entre outros, pelo constante incentivo, colaboração e participação na formação de um ambiente de trabalho e "póstrabalho" bastante agradável. Nestes itens inserem-se também muitos alunos da graduação do Instituto de Geociências.

Ao Departamento de Geologia Geral nas pessoas dos funcionários Nícia Maria Brandão Zalaf, Sônia Gomes Vieira Costa e Reynaldo Penã Castellon, pela especial atenção e serviços prestados aos alunos de pós-graduação.

Ao Prof. Dr. Thomas Fairchild pela revisão do abstract.

As pessoas que gentilmente nos receberam em Iraquara, Eduardo Figueiredo da Silva e família; Simpliciano Lima e família; Silvio Arruda e família; João Régis, família e funcionários da Pousada das Cavernas e; ao prefeito local Dr. Paulo e secretários municipais, entre outras pessoas.

Ao representante do Centro de Recursos Ambientais-CRA/BA na Região de Seabra Alóísio Cardoso pela gentil acolhida e por importantes auxílios prestados nos trabalhos de campo.

Ao Geológo Antônio Dourado da Rocha da CPRM/Salvador e ao Prof. Dr. Bejamin Bley de Brito Neves pelas sugestões bibliográficas e de aquisição de dados referentes ao Estado da Bahia.

A Companhia de Engenharia Rural da Bahia por ter permitido a utilização dos cadastos de dados de poços na pessoa do seu presidente Sr. Manfredo Pires.

Aos meus pais William e Rosa Medeiros Cruz e meus irmãos Williana, Williene e Wendel e, Sogros Cesar e Maria Regina Cristalli pelo apoio e carinho, comigo sempre presentes.

A FAPESP, Fundação de Amparo à Pesquisa do Estado de São Paulo pela concessão de bolsa através do processo 96/05685-4, além das importantes contribuições fornecidas pelos pareceres dos relatores a cerca dos relatórios semestrais.

Gostaria ainda de agradecer a todos que participaram direta ou indiretamente da realização deste trabalho que por ventura não encontram-se citados. 
1.1 - Apresentação do tema de trabalho

O Brasil possui várias regiões cársticas, que estão desenvolvidas principalmente em rochas carbonáticas com idade proterozóica, que segundo estimativas de Karmann (1994), ocupam 5 a $7 \%$ da área do país, com cerca de $8.500 .000 \mathrm{~km}^{2}$. As ocorrências de cavernas vêm sendo descobertas em diversas províncias cársticas, classificadas preliminarmente por Karmann \& Sánchez (1986). Auler \& Farrant (1996) apresentam resumidamente uma descrição atualizada das principais áreas cársticas e sistemas de cavernas brasileiros e também os principais trabalhos científicos produzidos no país até o momento, sobre a geologia e hidrogeologia do carste.

As rochas carbonáticas ocupam extensas áreas cársticas na região da Chapada Diamantina, situada na porção central do Estado da Bahia, região selecionada para o desenvolvimento do presente trabalho. Estas áreas compreendem terrenos, onde a dissolução das rochas carbonáticas se processa como um dos principais agentes de erosão e formação do relevo. Uma das principais características destes terrenos é a interrelação entre feições do relevo em superfície com a presença de sistemas de condutos em subsuperficie. Feições de relevo locais como, depressões cársticas, sumidouros de drenagens e ressurgências cársticas, entre outras feições, podem ser evidências do processo de desenvolvimento de sistemas de condutos em subsuperficie de acordo com Jennings (1985).

Os sistemas de condutos e fraturas alargadas constituem-se no principal meio de circulação de água em aqüíferos cársticos (Milanovic, 1981). Os aqüíferos cársticos, por sua vez, são considerados vitais para o abastecimento de água em regiões onde os sistemas fluviais de superfície estão quase ausentes, a exemplo das cidades e povoados situados no planalto cárstico de Irecê, na Chapada Diamantina (Negrão, 1987). O conhecimento da distribuição e modo de ocorrência de feições cársticas é necessário ao planejamento da ocupação humana e exploração dos bens naturais destas áreas. Isto porque existe uma diversidade de problemas ambientais relacionados por exemplo, com a grande susceptibilidade do aqüífero à poluição (Assaad \& Jordan, 1994), colapsos naturais ou induzidos de terrenos como conseqüência da presença de condutos (Becker \& Wilson, 1987), entre outros casos. 
As cavernas cársticas, definidas do ponto de vista geomorfológico, são representadas por condutos dissolucionais com diâmetro mínimo entre 5 e $15 \mathrm{~mm}$ (Ford \& Williams, 1989). A maioria das cavernas possuem menos de $50 \mathrm{~cm}$ de diâmetro. Uma faixa menos representativa de cavernas são acessíveis a exploração e mapeamento pelo homem, sendo que a maioria das ocorrências possuem menos de $1000 \mathrm{~m}$ de comprimento e $100 \mathrm{~m}$ de profundidade. As maiores cavernas, são aquelas que possuem mais de $100 \mathrm{~km}$ de comprimento em projeção horizontal e $1000 \mathrm{~m}$ de profundidade em projeção vertical (Courbon et al., 1989).

O mapeamento sistemático de cavernas possibilita a aquisição direta de informações de campo a respeito da formação de bacias de drenagens subterrâneas. A análise morfológica de passagens de cavernas consiste num importante método de trabalho utilizado para o estudo da evolução dos sistemas de cavernas, incluindo-se os estágios de abertura, ampliação e desenvolvimento de sistemas de cavernas, de acordo com Ford \& Ewers (1978), Palmer (1984), Palmer (1991) e Karmann (1994). O método utilizado leva em consideração parâmetros hidrológicos e geoespeleológicos no desenvolvimento dos condutos.

A maioria dos terrenos cársticos brasileiros são ainda pouco estudados sob o ponto de vista geomorfológico, geoespeleológico e hidrológico, mesmo que muitos destes terrenos apresentem consideráveis ocorrências de cavernas. Pretende-se, neste trabalho, contribuir no conhecimento do carste da Região da Chapada Diamantina, com o estudo de uma área situada ao sul do Planalto Cárstico de Irecê, caracterizada por grande densidade de cavernas e diversidade de feições cársticas em superficie. $\mathrm{Na}$ área de amostragem escolhida, os aspectos do carste são abordados em trabalhos, como Guerra (1986), Negrão (1987), Ferrari (1990) e Bahia (1993).

\section{2 - Localização e seleção da área de pesquisa}

A área de estudo está situada na região da Chapada Diamantina, porção centro-norte do Estado da Bahia e abrange parte dos municípios de Iraquara e Seabra (fig. 1.1). O acesso a Iraquara, que dista cerca de $450 \mathrm{~km}$ de Salvador, é feito pela BR-242, saindo de Salvador no sentido Brasília, até o entroncamento desta rodovia com a BR-330, no sul da área. Percorre-se $21 \mathrm{~km}$ a partir do entroncamento até a cidade de Iraquara pela BR-330, que prossegue em direção a cidade de Irecê. As cidades de Seabra, situada nas proximidades SW da área, e a cidade de Irecê, localizada $100 \mathrm{~km}$ a norte da mesma, são as principais cidades da região. 
Fig. 1.1 - Mapa de localização da área estudada.
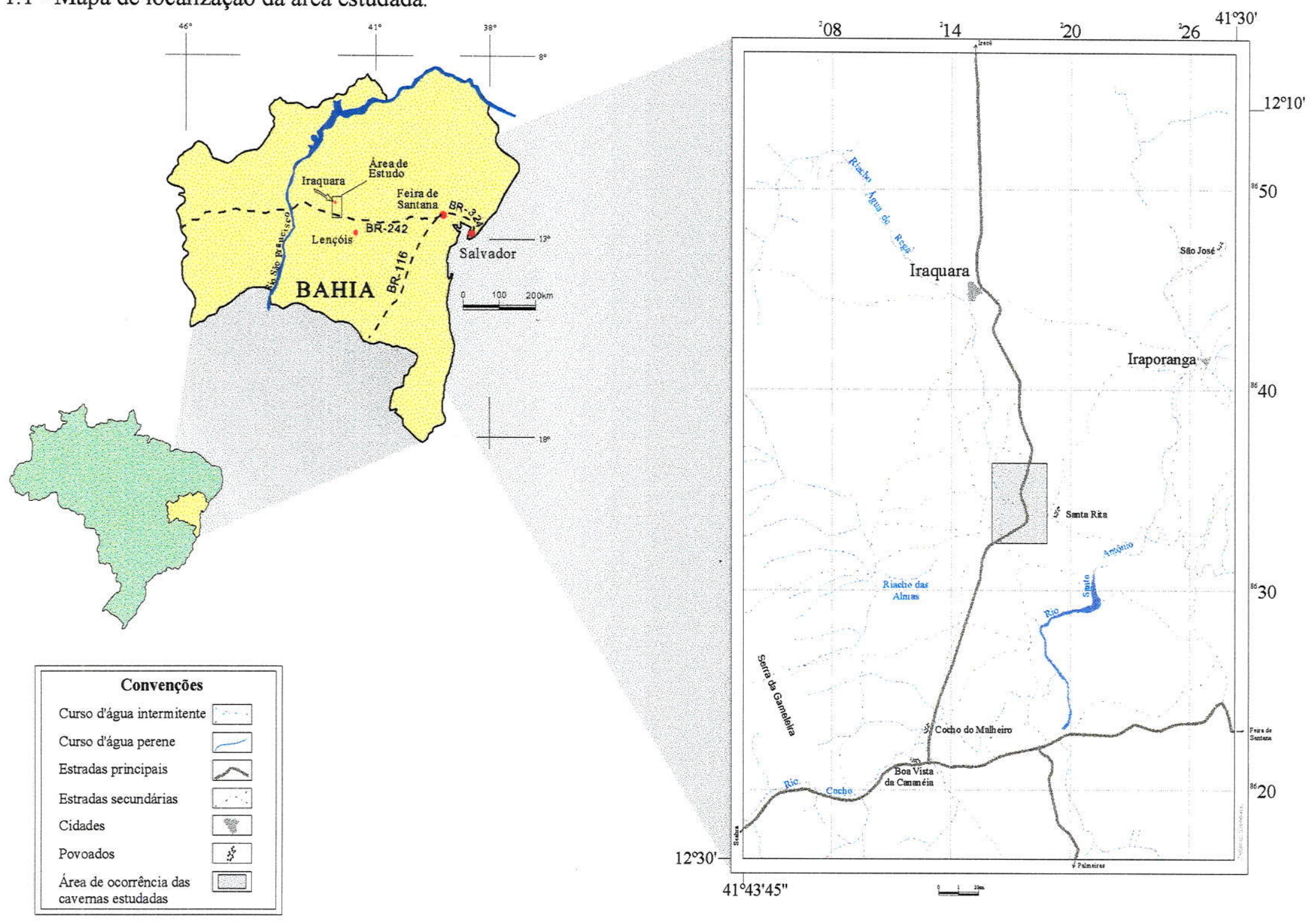
A região de Iraquara vem sendo alvo de exploradores de cavernas a partir de 1986, quando foi realizada uma expedição que envolveu a participação de franceses e brasileiros do Grupo GEECE de Fortaleza-CE. Por motivo da descoberta e mapeamento de grandes cavernas, a exemplo da caverna da Lapa Doce, vários grupos espeleológicos vêm descobrindo novas ocorrências de cavernas, todavia somente uma pequena parte do total descoberto foi mapeado topograficamente até o momento.

O cadastramento das cavernas é realizado pela Sociedade Brasileira de Espeleologia-SBE, que congrega dados de cavernas brasileiras, enviados por grupos de espeleologia e entidades ambientalistas, através do Cadastro Nacional de Cavidades Naturais. Existem outros levantamentos feitos em paralelo pelo Grupo Bambuí de Pesquisas Espeleológicas-GPBE, Belo Horizonte/MG (Rubbioli, 1995) e pelo Centro de Recursos Ámbientais da Bahia, Seabra-BA (Aloísio Cardoso, informação verbal, 1997).

Uma considerável quantidade de dados relativos à localização de cavernas e o mapeamento topográfico de amplas cavernas com mais de $1 \mathrm{~km}$ de passagens (Rubbioli, 1995) são fatores que influenciaram na escolha da área de estudo para a pesquisa desenvolvida. $O$ conhecimento prévio da ocorrência de cavernas facilitou consideravelmente a formulação de questões a serem investigadas, ao longo do trabalho. Já a porção norte do planalto cárstico de Irecê não possui muitas ocorrências registradas se comparada a porção sul, porém trata-se de uma setor do ainda pouco investigado do ponto de vista da exploração de cavernas.

A área dos sistemas de cavernas da Lapa Doce e Lapa da Torrinha, localizadas na influência do sumidouro do Riacho Água de Rega, foram escolhidas para serem estudadas mais detalhadamente (fig.1.1). A maior dimensão destes sistemas em relação às demais ocorrências, a diversidade de padrões morfológicos e a correlação direta com importantes feições cársticas em superfície foram os critérios adotados nessa escolha.

\section{3 - Objetivos da pesquisa}

O objetivo principal do trabalho consistiu em descrever as ocorrências de feições cársticas em superficie e subsuperficie de um terreno cárstico, sob o ponto de vista geomorfológico, geoespeleológico e hidrológico, e assim esboçar um quadro preliminar da evolução do relevo e sistemas de cavernas na área. Desta forma, teve-se os seguintes objetivos específicos: 
i) Obter a distribuição e os tipos de feições cársticas identificadas em superficie, através de mapeamento fotogeológico.

ii) Aquisição de parâmetros morfométricos através de análises bidimencionais de depressões cársticas fechadas em superfície.

iii) Caracterizar a morfologia de setores dos sistemas de cavernas Lapa Doce e Lapa da Torrinha, que apresentam diferentes tipos de padrões morfológicos, com base em plantas topográficas, seções transversais e perfis longitudinais.

iv) Identificar a influência de parâmetros geológicos e hidrológicos no condicionamento morfológico durante as fases de abertura e modificação de condutos, com base no mapeamento geoespeleológico e das paleorotas de fluxo hidrológico.

v) Traçar a história evolutiva da abertura de condutos, abrangendo as fases de iniciação, desenvolvimento e modificação da morfologia de cavernas e o condicionamento morfológico dos sistemas de cavernas estudados por fatores geológicos e hidrológicos.

vi) Correlacionar a ocorrência de feições do relevo cárstico em superfície com o desenvolvimento de cavernas.

\section{4 - Metodologia de trabalho}

Os métodos e técnicas empregados, apresentados abaixo em linhas gerais, serão detalhados posteriormente nos seus respectivos itens com os quais estão relacionados.

i) Interpretação de fotografias aéreas nas escalas 1:25.000 e 1:60.000, a partir da qual, são traçadas a rede de drenagem, as feições cársticas de superficie e os lineamentos fotogeológicos que constituem os mapas morfológicos. Os contatos geológicos foram obtidos da compilação de mapas geológicos de Souza et al. (1993) e Pedreira-da-Silva (1994) e das observações da fotointerpretação.

ii) Medição de parâmetros morfométricos diretamente nos mapas morfológicos e através do tratamento deste mapas em versão digitalizada, por técnicas de geoprocessamento.

iii) Mapeamento topográfico e morfológico de setores de cavernas, com o objetivo produzir plantas, perfis longitudinais e seções transversais que ressaltem diferentes padrões morfológicos nos sistemas de cavernas estudados. 
iv) Mapeamento geoespeleológico e levantamento de paleofluxo, utilizando a base cartográfica confeccionada durante a topografia dos setores de cavernas.

v) Correlação de dados em geral utilizando histogramas de freqüência e testes estatísticos. 


\section{1 - Contexto geológico}

\subsection{1 - A Bacia de Irecê e as rochas carbonáticas}

A região cárstica em estudo está inserida na porção sul do sinclinal de Irecê (Inda \& Barbosa, 1978) ou Bacia de Irecê (Souza et al., 1993), no domínio do Cráton do São Francisco (fig. 2.1). Esta faixa de ocorrência de rochas carbonáticas possui orientação N-S e extensão aproximada de $200 \mathrm{Km}$, com largura variando entre 15 e $100 \mathrm{~km}$, que diminui para sul. Outras faixas carbonáticas na região da Chapada Diamantina estão situadas em porções mais a sudeste e nordeste da área estudada, destacando-se, por sua dimensão, a faixa que envolve as localidades de Iramaia e Utinga, a sudeste.

A mesma é composta por duas seqüências sedimentares neoproterozóicas, uma formada por rochas com composição terrígena na base e, uma outra de composição carbonática, no topo, pertencentes respectivamente às Formações Bebedouro e Salitre, do Grupo Una e Supergrupo São Francisco (Inda \& Barbosa, 1978). Estas formações encontram-se depositadas discordantemente sobre os metassedimentos do Supergrupo Espinhaço, de idade mesoproterozóica, segundo Misi (1979). O último autor correlacionou os carbonatos da Formação Salitre aos da Formação Sete Lagoas do Grupo Bambuí, na Serra do Espinhaço (extensão baiana), Minas Gerais e Goiás, de acordo com as suas características litoestratigráficas. $\mathrm{Na}$ região estudada (fig. 2.1), as rochas carbonáticas são sotopostas por litologias dominantemente siliciclásticas, pertencentes aos grupos Chapada Diamantina e Paraguaçu, segundo Pedreira-da-Silva (1994).

Misi (1979) e Misi \& Silva (1996), descrevem a existência de cinco unidades aflorantes na Bacia de Irecê, denominadas de $\mathbf{A}_{1}, \mathbf{A}, \mathbf{B}_{1}, \mathbf{B}$ e $\mathbf{C}$. A unidade $\mathbf{A}_{1}$, no topo da seqüência, constitui a fácies carbonática mais bem representada em toda a região, sendo formada por calcilutitos maciços, pretos e calcários oolíticos a pisolíticos, depositados em ambiente marinho raso. A unidade $\mathbf{A}$, é caracterizada pela predominância de metargilitos calcíferos, depositados em mar profundo, que possuem coloração cinza-escura, quando não alterado ou cinza avermelhado, quando alterado. A unidade $\mathbf{B}_{1}$, é formada por camadas descontínuas de doloarenito e dololutitos 
Fig. 2.1 - Localização da área estudada no contexto das coberturas carbonáticas neoproterozóicas da região da Chapada Diamantina

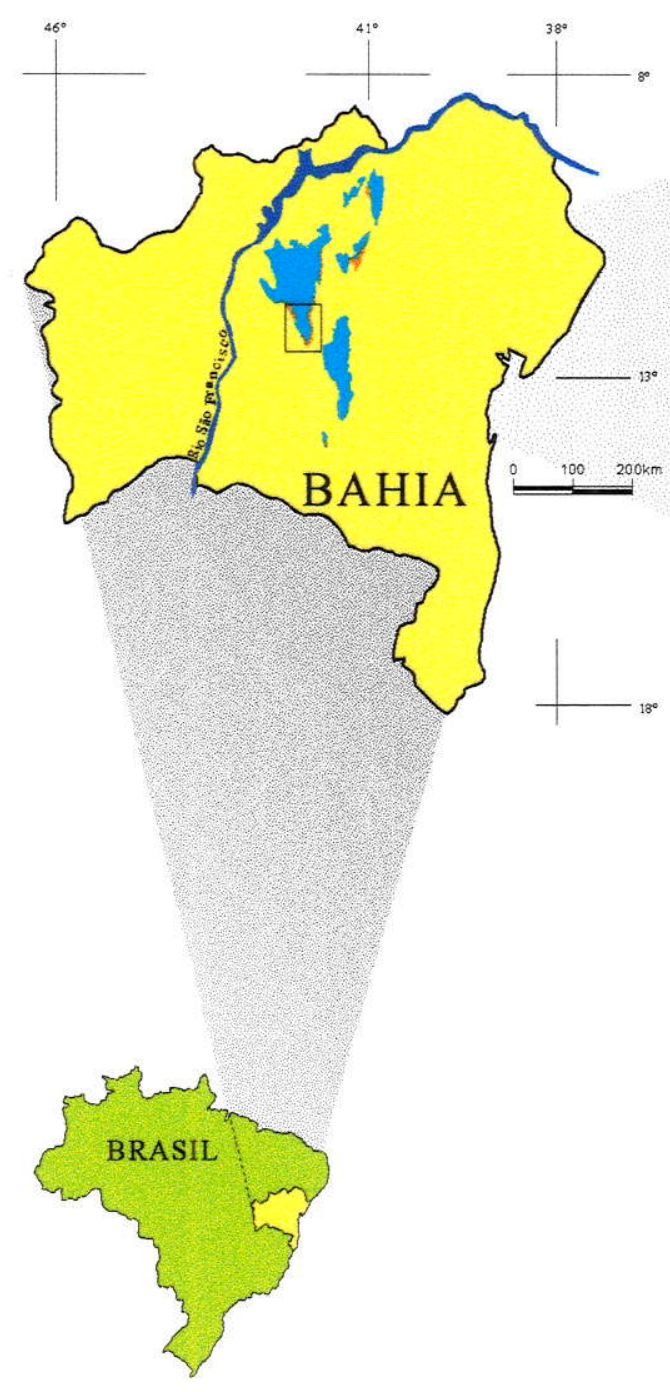

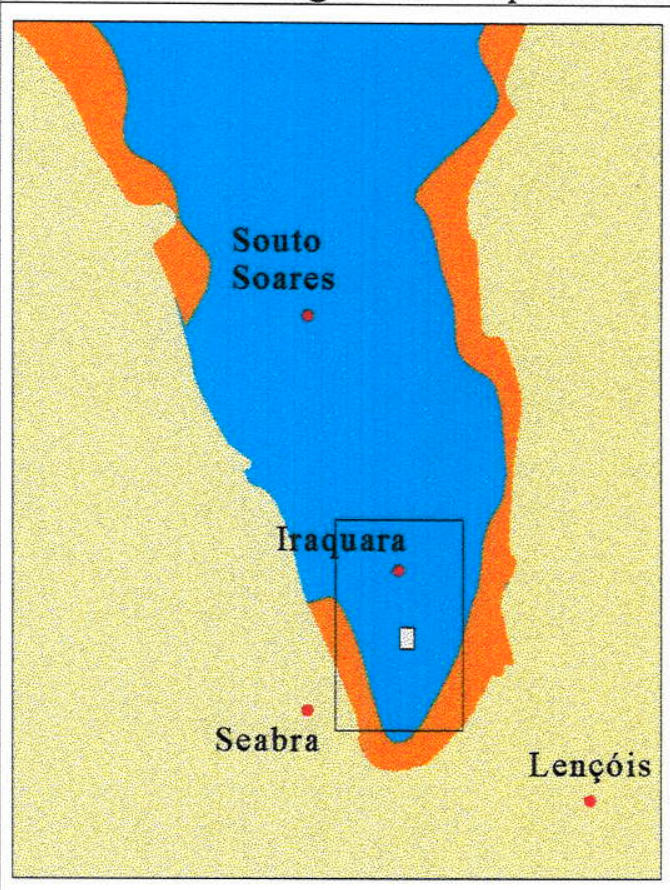

Bacia de Irecê

\begin{tabular}{|l|}
\hline \multicolumn{2}{|c|}{ Convenções } \\
Cidades \\
Rochas carbonáticas \\
das formaçôes Salitre \\
ou Sete Lagoas \\
Rochas sedimentares \\
clásticas da Formação \\
Babedouro \\
Grupos Chapada \\
Diamantina e \\
Paraguaçu \\
Área de detalhe dos \\
sistemas de cavernas
\end{tabular}


silicosos de coloração cinza-clara e rosada, apresentando níveis individualizados de sílex. A unidade B, caracteriza-se pela presença predominante de calcários cinza-claro, muito finos e laminados, contendo finas lâminas de argila e, por fim, a unidade $\mathbf{C}$, representada por dolomitos e calcários dolomíticos com laminações algais, está situada na base da seqüência carbonática. As fácies carbonáticas pertencentes as unidades $\mathbf{B}_{1}, \mathbf{B}$ e $\mathbf{C}$ foram classificadas como de ambiente marinho raso e estão dispostas mais para a borda da faixa carbonática em relação as fácies $\mathbf{A}_{\mathbf{1}}$ e $\mathbf{A}$.

Souza et al. (1993) redefiniu a litoestratigrafia da Bacia de Irecê em unidades informais, de acordo com ciclos de sedimentação marinha transgressiva e regressiva. A mesma classificação foi adotada por Dominguez (1996).

As unidades Nova América Inferior e Superior foram associadas à fases de regressão marinha, caracterizadas por fácies carbonáticas de mar raso, depositadas em zonas de intermaré e supramaré. Na Unidade Nova América Inferior afloram calcissiltitos cinza-clara azulados, rosados e cremes com laminação plano-paralela e laminitos algais negros, enquanto na Unidade Nova América Superior afloram doloarenitos e doloarenitos oolíticos e oncolíticos, cinza claro a escuros.

As unidades Jussara Inferior, Jussara Superior e Irecê foram associadas à fases de transgressão marinha. As duas primeiras unidades são caracterizadas por fácies carbonáticas de mar mais profundo, depositadas em zonas de submaré superior a inferior, enquanto a última Irecê teria se depositado em zona de talude. A Unidade Jussara Inferior está representada por calcissiltitos e calcilutitos apresentando estratificações plano paralela e calcarenitos oolíticos ou pisolíticos geralmente maciços. A Unidade Jussara Superior está representada por calcarenitos oolíticos a oncolíticos de cor cinza a negra. A Unidade Irecê está representada por uma alternância de níveis carbonáticos formados por calcarenitos a calcilutitos escuros e níveis terrigenos formados por margas, siltitos e arenitos.

\subsection{2 - Situação tectônica e geologia estrutural}

As rochas que compõem as coberturas meso a neoproterozóicas do Cráton do São Francisco, na região da Chapada Diamantina, foram depositadas conforme Dandefer-Filho (1990) e Mise \& Silva (1996), em uma bacia do tipo rift intracontinental ou aulacogênica. A história de evolução desta bacia, sintetizada por Mise \& Silva (1996), iniciou-se há 1,7Ga, com a ruptura de 
parte do embasamento por falhamentos extensionais de direção NNW-SSE, concomitantemente com a deposição das rochas da Formação Paraguaçu e Vila dos Remédios. Posteriormente ocorreram os eventos de alargamento e subsidência da bacia e sedimentação das rochas pertencentes ao Grupo Chapada Diamantina e Grupo Una. O estágio final de evolução é caracterizado pela inversão do sulco da bacia e elevação das coberturas, a qual teria ocorrido no final do Proterozóico Superior.

A região estudada é caracterizada pela ocorrência de um conjunto de megadobras, cujo estilo é representado pela sucessão de suaves anticlinais e sinclinais, de dimensões variáveis entre quilômetros e dezenas de quilômetros (Dandefer-Filho, 1990). Os eixos dessas dobras orientamse segundo a direção NNW-SSE.

Misi (1979) descreve que a faixa carbonática consiste em um grande sinclinal, margeado por dois anticlinais, a oeste e a leste na direção de maior prolongamento da faixa. Os mergulhos das camadas do platô carbonático são suaves, variando entre $10 \mathrm{a} 15^{\circ}$.

Outras estruturas representativas do mesmo evento de formação das dobras regionais, segundo Dandefer-Filho (1990), são as falhas de empurrão de alto ângulo, com direção NNWSSE e diversos tipos de fraturas. Os principais conjuntos de fraturas medidas principalmente em rochas do Grupo Chapada Diamantina, correspondem a juntas longitudinais com espaçamento métrico e direção perpendicular ao eixo das dobras regionais; fraturas diagonais ao eixo das dobras, com direções NE-SW e E-W e também as fraturas preenchidas, com direção WSW-ENE. Proeminentes sistemas de fraturamentos regionais, descritos a partir de fotografias aéreas na região de Barra do Mendes a noroeste da área, possuem orientação NNW-SSE.

Dobras e falhas de empurrão de traço E-W, com vergência para sul, como também falhas e fraturas direcionais de orientação NNW-SSE e N-S, são descritas por Lagoeiro (1990, apud Dandefer-Filho 1990) nos carbonatos da Formação Salitre a norte da Bacia de Irecê.

\section{2 - Situação Geomorfológica}

O relevo da Chapada Diamantina é caracterizado pela presença de planaltos e serras, situados em altitudes que variam entre 300 a $1700 \mathrm{~m}$. As diferenças altimétricas e morfológicas do relevo acompanham geralmente a disposição dos litotipos ocorrentes na região. 
$\mathrm{Na}$ área de estudo são reconhecidos dois domínios geomorfológicos bem abrangentes na região: um deles está representado pelos planaltos cársticos e o outro corresponde a planaltos e serras em litologias predominantemente siliciclásticas, conhecidos regionalmente como Gerais (Nunes et al., 1981; Pedreira-da-Silva, 1994). Os planaltos cársticos ocorrem na área, nos intervalos de altitudes situados entre 600 a $800 \mathrm{~m}$ e os planaltos e serras em rochas siliciclásticas nos intervalos subseqüentes de 800 a $1.100 \mathrm{~m}$ (fig. 2.2).

Segundo Nunes et al. (1981) e Pedreira-da-Silva (1994), as superficies do relevo nos planaltos dos Gerais e nos planaltos cársticos, são correlacionáveis, respectivamente às superficies de aplainamento dos ciclos Sul-Americano e Velhas, definidas por King (1956).

\section{Domínio dos planaltos cársticos}

O planalto cárstico é caracterizado por relevos suavemente ondulados situados no sopé das maiores elevações, o qual, possui cotas máximas entre 750 a $800 \mathrm{~m}$, junto ao contato geológico com as rochas não carbonáticas e também na porção norte da área (fig. 2.2). Feições importantes desse planalto corresponde a presença de vales bem encaixados com vertentes escarpadas, ultrapassando em alguns casos $40 \mathrm{~m}$ de profundidade e a ocorrência de uma grande quantidade de depressões cársticas. Os pontos mais baixos do relevo são encontrados ao longo do vale do Rio Santo Antônio, com piso situado a aproximadamente $600 \mathrm{~m}$ de altitude. Este vale compreende o nível de base do aqüífero na área.

A maior parte do planalto cárstico na área de estudo encontra-se coberto por solos carbonáticos e também por depósitos coluvionares e aluvionares. No restante do planalto de Irecê, os trechos com rochas aflorantes são mais comuns, sendo freqüente a ocorrência de campos de lapiás associados, como descreve Guerra (1986). Este autor observa diferenças relevantes na morfologia de depressões cársticas, no setor norte do planalto e na porção sul, onde está inserida a área de pesquisa. A norte, as dolinas são menores, mais rasas e esparsas do que na parte sul do planalto.

Tricart \& Silva (1968) e Nunes et al. (1981) diferenciam pela densidade de talvegues o planalto cárstico na região de Irecê, daquele situado entre Utinga e Iramaia, a sudeste. $\mathrm{Na}$ primeira região, os vales são considerados em geral meros sulcos secos que entalham fracamente os tabuleiros, e no Planalto Utinga-Iramaia, a rede de drenagem é tida como mais densa devido a ocorrência de vales com entalhamentos mais pronunciados, possuindo planícies aluviais contínuas. 


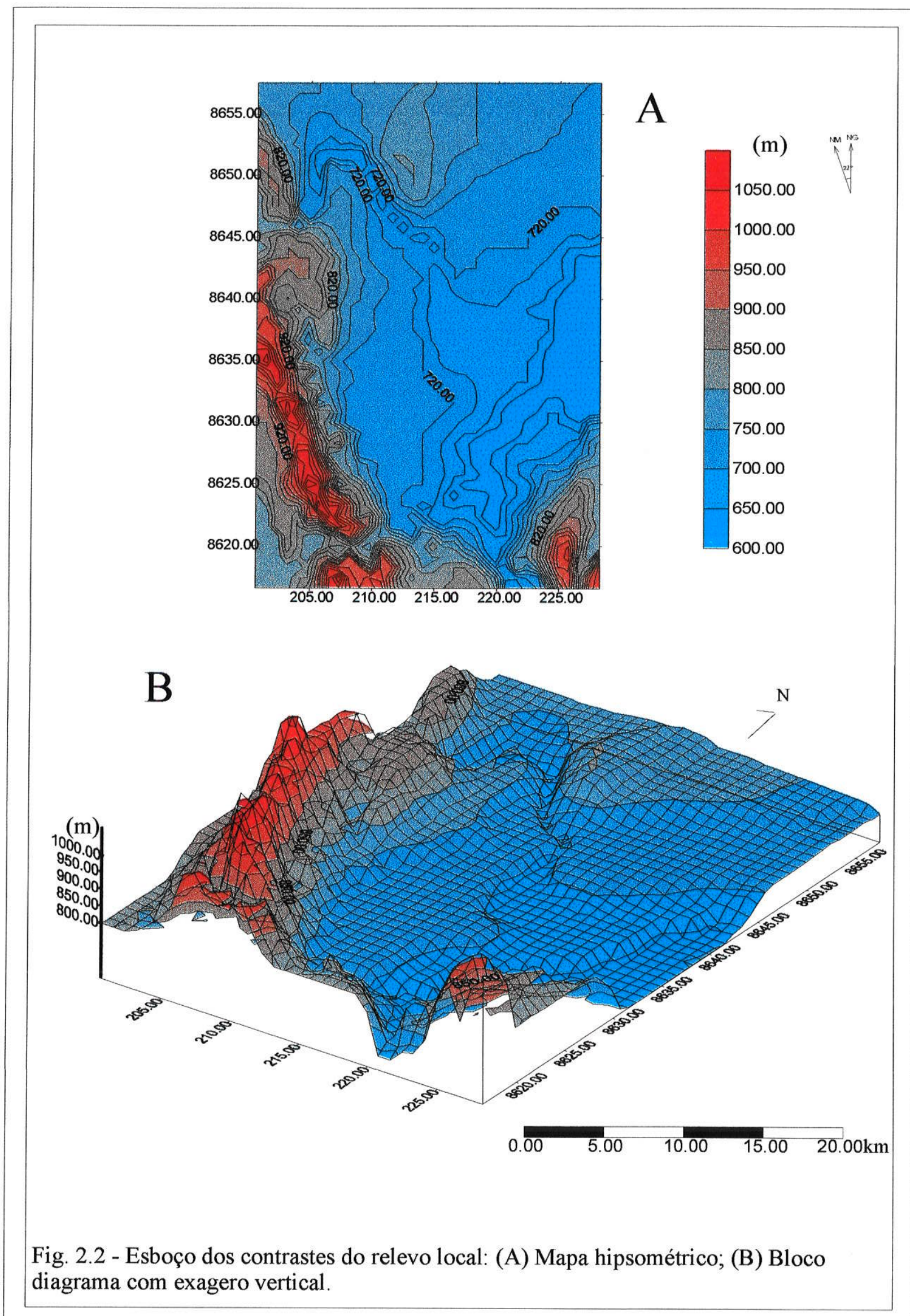


Ferrari (1989) discute que o Planalto de Irecê é menos dissecado, porque não apresenta discontinuidades marcantes, comparada ao Planalto Utinga-Iramaia, que exibe formas residuais do tipo kegelkarst nas proximidades de Ituaçu, caracterizado por morros testemunhos constituídos de rochas carbonáticas.

$\mathrm{Na}$ região próxima a Itaetê, ao centro do Planalto Utinga-Iramaia, estão presentes expressivos morros testemunhos carbonáticos dispostos entre o vale do Rio Una e as rochas do embasamento cristalino, no domínio da depressão sertaneja (Pereira, 1998). Os topos destes morros possuem altitudes semelhantes ao topo do planalto em rochas siliciclásticas nas proximidades locais. No Planalto de Irecê este tipo de feição é menos comum, e ocorre sempre com cotas mais baixas em relação ao relevo em rochas siliciclásticas.

\section{Domínio dos planaltos dos gerais}

Este domínio corresponde as porções mais altas do relevo na área e é caracterizado por planaltos e serras em rochas siliciclásticas bordejados por escarpas íngremes, que contrastam com o relevo planalto cárstico a leste e oeste da área (fig. 2.2).

As principais elevações estão situadas em serras de rochas areníticas. Na porção leste da área, as encostas das serras iniciam-se em altitudes de 750 a $800 \mathrm{~m}$, ultrapassando pouco mais de 1000m nos topos dos Morros do Pai Inácio e Morro do Camelo. Já a oeste da área, as serras da Gameleira e Santo Antônio chegam a alcançar altitudes próximas a 1200m.

2.3 - Distribuição de sistemas de cavernas e direção geral do fluxo hidrológico

\section{Distribuição dos sistemas de cavernas}

As cavernas podem ser encontradas em toda a área de estudo, contudo existe uma concentração preferencial situada nas porções central e leste do mapa hipsométrico (fig. 2.2), numa faixa de relevo com altitude variando entre 750 e 650m (nível topográfico do Rio Santo Antônio). O mapa da figura 2.3, mostra a distribuição de cavernas na parte central da área, com base no levantamento feito por Rubbioli (1995). A maioria das ocorrências estão situadas na parte centro-leste do mapa (fig. 2.3), junto aos sumidouros dos riachos Água de Rega e das Almas e no trecho entre os estes sumidouros e a margem esquerda do Rio Santo Antônio. 


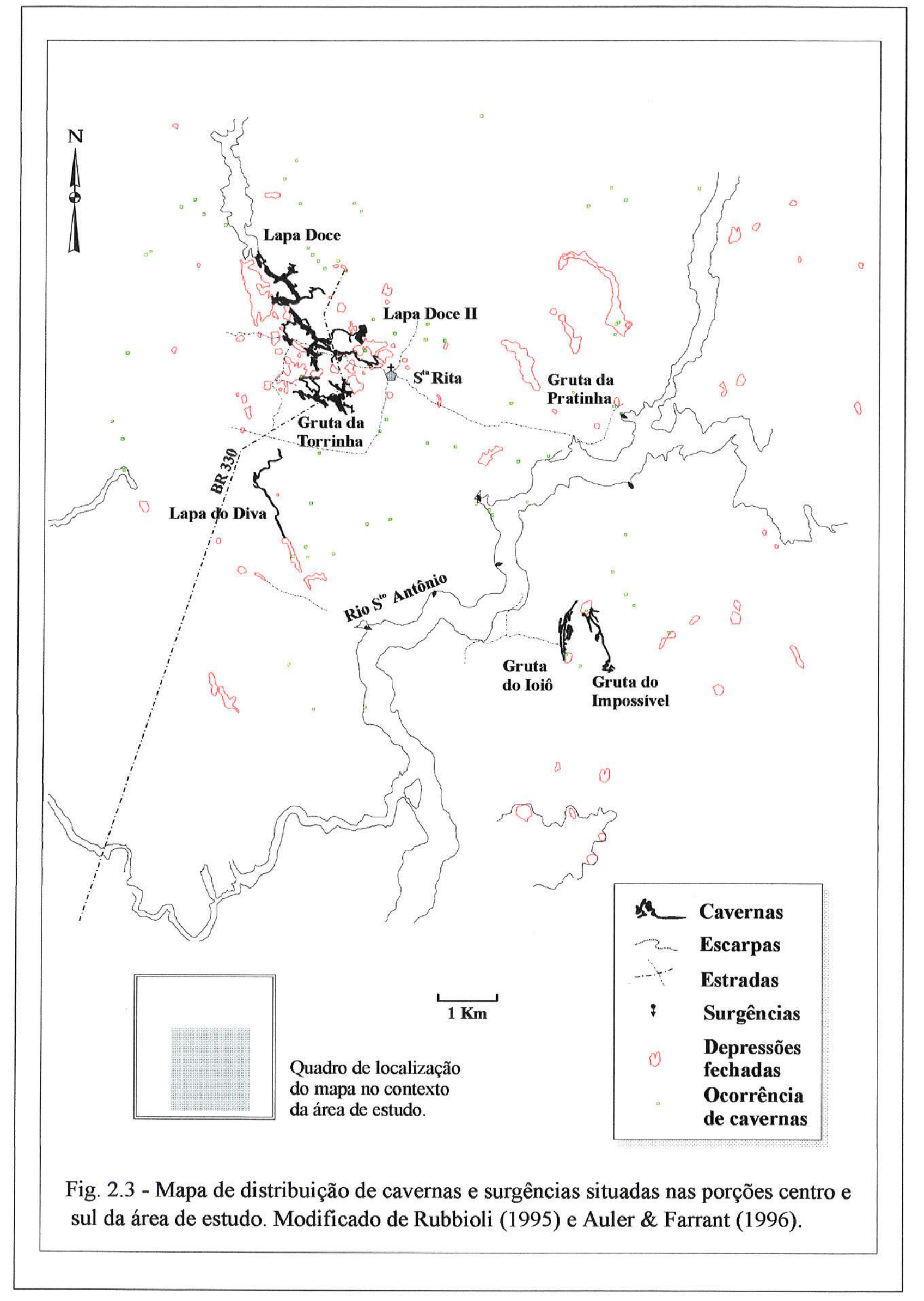


Outras importantes ocorrências estão distribuídas ao longo da margem esquerda do Rio Santo Antônio nas proximidades das ressurgências do Rio Preto e da Pratinha e também na porção sudeste do mapa. As demais cavernas encontram-se dispersas em outros pontos da área de exposição dos carbonatos.

Os Sistemas de Cavernas Lapa Doce ou Santa Rita (Ferrari, 1990) e Lapa da Torrinha, situados nas proximidades do Sumidouro do Riacho Água de Rega, são os mais extensos, respectivamente, com $17,0 \mathrm{~km}$ e $8,3 \mathrm{~km}$ de desenvolvimento horizontal (Panchout \& Panchout, 1995). Rubbioli (1995) separa espeleometricamente o Sistema Lapa Doce em Cavernas Lapa Doce I (6,5km) e Lapa Doce II $(9,8 \mathrm{~km})$, com o argumento que uma dolina de colapso interrompe a continuidade entre os dois ramos do Sistema. As demais cavernas com grandes dimensões são a Gruta do loiô (4,0km), Lapa do Diva (3,9km), Sistema Cão-Talhão (3,0km), Gruta Azul (2,5km) e Gruta do Impossível $(2,35 \mathrm{~km})$.

As cavernas, ao longo de diferentes pontos da área, apresentam padrões morfológicos dominantes como: condutos em rede (Palmer, 1984; 1991), grandes salões de abatimentos, distributários (Palmer, 1984) e condutos principais(fig. 2.4). O padrão reticulado foi constatado principalmente em cavernas situadas nas proximidades da margem esquerda do Rio Santo Antônio, junto ao entroncamento com o Riacho do Gado, a exemplo das Grutas Azul, Veado Galheiro e Lagoa Seca (fig. 2.4a). As cavernas com padrão de grande salões de abatimento são as mais comumente encontradas em toda área do planalto carbonático, a exemplo da Gruta do Zé Libano, Jaburu, Santa Marta e Conceição (fig. 2.4b). O padrão distributário caracteriza o Sistema Lapa Doce, que possui ramos de condutos que se iniciam numa galeria principal de maior dimensão, desenvolvendo-se no sentido da jusante da drenagem subterrânea (fig. 2.4c). Nas Grutas do Diva e do Impossível, respectivamente, situadas na margem esquerda e direita do Rio Preto, predominam padrões de condutos principais com poucas ramificações (fig. $2.4 \mathrm{~d}$ ).

\section{Direção geral do fluxo hidrológico}

$\mathrm{Na}$ área de estudo as direções mais favoráveis do gradiente hidráulico são influenciadas por significativas diferenças altimétricas de 350 a 450m, entre as cristas de rochas areníticas, que constituem os principais divisores de drenagem e o vale do Rio Santo Antônio, que corresponde ao nível de base local (fig. 2.2). As cristas estão posicionadas nas direções NNE-SSW e NW-SE, respectivamente, nos lados $\mathrm{E} \mathrm{e} \mathrm{W}$ da área e tendem a convergir ao Sul da mesma. 


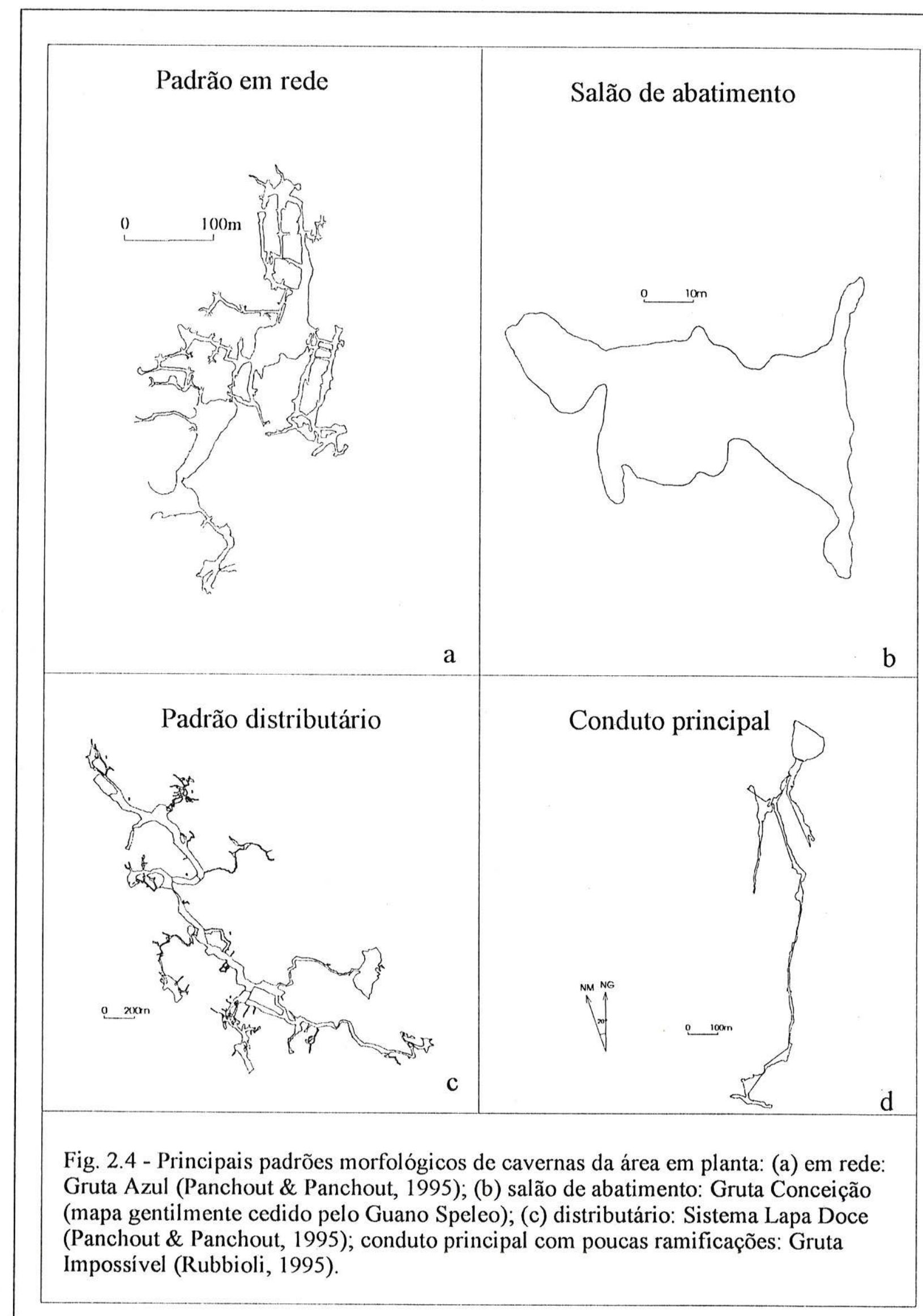


O Rio Santo Antônio, situado na porção centro-sul, desloca-se para NNE e inflexiona-se bruscamente para leste na proximidade da Fazenda Pratinha, atravessando as serras de metarenito.

Neste contexto, é importante comentar que a direção dos vales cársticos, fluviocársticos e cavernas maiores é transversal às escarpas situadas nas margens do Vale do Rio Santo Antônio.

As direções das rotas de fluxo que predominam em determinados locais da área podem ser inferidas a partir da análise direta do posicionamento em planta de cavernas, considerando os prováveis pontos de recarga e descarga do fluxo de água (fig. 2.3). As cavernas situadas na margem esquerda do Rio Santo Antônio demonstram direção geral de fluxo de NW para SE no caso dos Sistema Lapa Doce e Lapa da Torrinha e N para S na Gruta do Diva. As grutas do Ioio e Impossível, situadas na margem direita do Rio Santo Antônio, na porção SE da área, possuem direção geral de fluxo SE para NW (fig. 2.3).

A direção geral do fluxo subterrâneo pode ser observada também a partir do mapa potenciométrico, de acordo com a configuração das curvas piezométricas gerada com os valores da diferença entre as medidas de altitude e profundidade do nível estático de 37 poços tubulares da Companhia de Engenharia Rural da Bahia - CERB distribuídos pela área (fig. 2.5). Os dados desse mapa devem ser analisados com cautela, levando em consideração a grande variação local na profundidade de superficies piezométricas, comum em áreas cársticas e ao pequeno número de poços analisados. Isto porque as cavernas representam níveis de base locais, para onde escoam a água de cavernas menores e também do aqüífero fraturado, influenciando assim, mudanças freqüentes na configuração do lençol freático (Ford \& Williams, 1989). Apesar disso, os mapas potenciométricos podem ser bastante úteis na descrição das linha de fluxo de aqüiferos cársticos, principalmente quando apresentados juntamente com rotas de fluxo delineados por técnicas de traçadores (Quinlan \& Ewers, 1981).

No mapa potenciométrico da área (fig. 2.5), o gradiente e sentido de fluxo não são precisos, entretanto pode-se deduzir quais são os setores com maiores e menores valores de gradientes de fluxo e a orientação dos quadrantes das linhas de fluxo. Os gradientes de fluxo são maiores a oeste, na área representada pelas encostas de serras em litologias não carbonáticas, representadas por curvas com valores acima de $700 \mathrm{~m}$. A área de exposição das rochas carbonáticas são caracterizadas por gradientes suaves, mais para o centro da área, representado no mapa por curvas com valores inferiores a $700 \mathrm{~m}$. As linhas de fluxo hipotéticas interpretadas a partir do referido mapa, convergem para o Vale do Rio Santo Antônio. Os sentidos de fluxo 


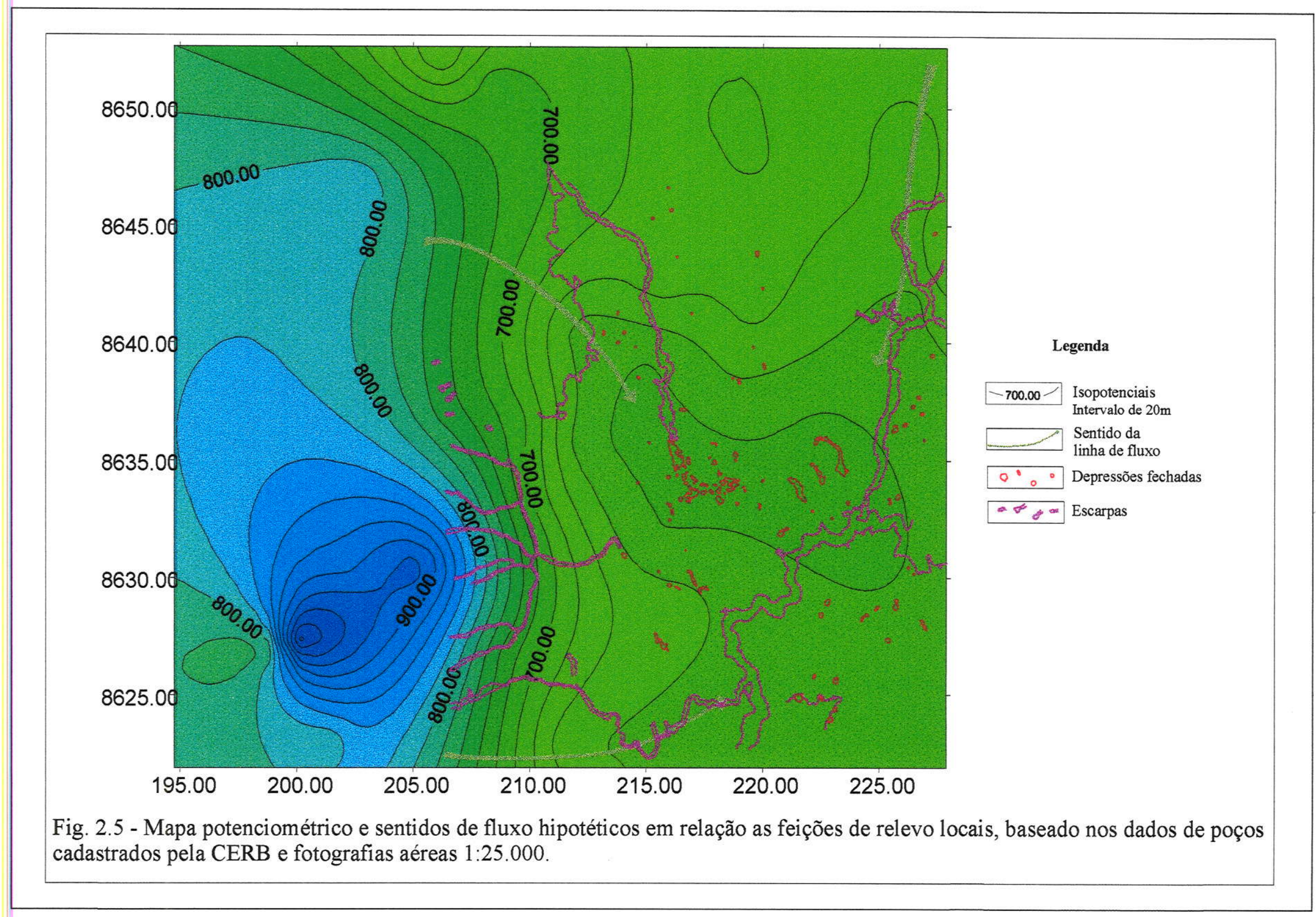


encontrados na porção centro-sul e oeste do mapa estão voltados para os quadrantes NE e SE. Já na porção centro-norte e nordeste do mapa, as linhas de fluxos confluem para os quadrantes SW e SE. As drenagens e vales cársticos acompanham aproximadamente o traçado das linhas de fluxo do mapa potenciométrico.

Segundo Guerra (1986), existe um alto potenciométrico importante ao norte de Iraquara que funciona como divisor de água entre as bacias dos rios São Francisco e Paraguaçu. A norte deste divisor o fluxo escoa no sentido centro a borda da bacia carbonática, diferentemente do que ocorre a sul do divisor, na área estudada.

\section{4 - Vegetação}

A área de estudo caracteriza-se por dois tipos de vegetação distribuídas ao longo dos setores norte e sul, de acordo com Brazão e Araújo (1981). Observa-se que, na atualidade, as áreas vegetadas estão restritas, principalmente, às proximidades das serras, no interior das depressões, ou acompanhando os vales.

Nas regiões centro e norte da área, principalmente em áreas com altitudes até cerca de $700 \mathrm{~m}$, predomina a vegetação de caatinga. As árvores e arbustos que compõem esta vegetação, perdem a folhagem durante o período de seca, o que diminui a transpiração ao mínimo. Ela está representada por plantas lenhosas deciduais, compostas por muitas fanerógramas espinhentas, cactáceas suculentas sem folhas e tufos eventuais de gramíneas, com composição florística bem diversificada.

A vegetação do sul-sudoeste da área estudada é constituida por plantas herbáceas graminosas contínuas, coberta por plantas lenhosas. A estrutura da vegetação encontra-se relacionada ao clima de duas estações: uma chuvosa e outra seca. No vale do Rio Santo Antônio, encontra-se representada uma vegetação de cerrado na qual a percentagem de decidualidade situa-se entre 20 a $50 \%$ dentro do conjunto da vegetação, durante a época desfavorável. Essa decidualidade ocorre principalmente nas árvores mais altas. A estrutura da vegetação no vale é semelhante a de uma Floresta Ciliar, diferindo-se apenas floristicamente. No restante desta área, a percentagem de decidualidade dos indivíduos dominantes passa a ser de $50 \%$ ou mais, atingindo também a submata, conhecida como Mata de Cipó (Brazão \& Araújo, 1981). 
A área que compreende a superficie carbonática é extensivamente utilizada para lavoura de subsistência, hortaliças e plantações de mamona. A agricultura é uma das principais atividades que provocaram a destruição uma parte considerável da vegetação original da área.

\section{5 - Clima}

A área de estudo está situada numa faixa climática sub-úmida a semi-árida de acordo com a classificação de Thornthwait, com temperatura média anual que varia entre 20 e $22^{\circ} \mathrm{c}$ (Gonçalves \& Pereira, 1981). A região sudoeste apresenta um clima mais sub-úmido, enquanto a região noroeste o clima tende a ser mais semi-árido.

$\mathrm{Na}$ região somente estão definidas as estações de verão e inverno, que correspondem respectivamente aos meses mais secos e chuvosos do ano. A pluviometria varia acentuadamente na área, com média anual de $700 \mathrm{~mm}$ na porção noroeste e $1.100 \mathrm{~mm}$ na porção sudoeste. $\mathrm{O}$ período com maior incidência de chuvas situa-se entre os meses de novembro e abril, enquanto o período mais seco ocorre entre os meses de junho e setembro. A área possui uma deficiência hídrica anual que varia de 100 a $200 \mathrm{~mm}$ no sudoeste da área e chega a ser superior a $300 \mathrm{~mm}$, no nordeste da área. 
3.1 - Arcabouço geológico e aspectos gerais da morfologia cárstica

A origem e distribuição de feições cársticas está direta ou indiretamente relacionada a fatores geológicos, intrínsecos às rochas carstificáveis de uma determinada área. Os fatores geológicos mais relevantes são o tipo de litologia, a espessura do pacote carbonático, a seqüência litoestratigrafica, a estrutura geológica e a porosidade (White, 1988).

\section{Litoestratigrafia local}

As seqüências litológicas presentes na área de estudo encontram-se representadas no mapa de fenômenos cársticos (Anexo 1). Os contatos geológicos nos limites de exposição das rochas pertencentes ao Grupo Una e das litologias não-carbonáticas tiveram como base os trabalhos de Souza et al. (1993) e Pedreira-da -Silva (1994).

As litologias carbonáticas estão distribuídas da borda para o centro da área e pertencem, respectivamente, às unidades Nova América Inferior e Nova América Superior, de acordo com Souza et al. (1993). A Unidade Nova América Inferior está representada por uma faixa estreita que bordeja as rochas não-carbonáticas, constituída de calcários dolomíticos, calcissiltitos e laminitos algais. A mesma representa a base da Formação Salitre na área, estando em contato com os litotipos da Formação Bebedouro à oeste e a sul, como também com os litotipos da Formação Caboclo do Grupo Chapada Diamantina, à leste. A Unidade Nova América Superior é constituída por dolomitos que afloram na porção centro-norte da área. Os litotipos de composição predominantemente siliciclástica que compõem os Grupos Chapada Diamantina (formações Morro do Chapéu, Cabloco e Tombador) e Grupo Paraguaçu, estão posicionadas nas bordas sul, leste e oeste da área de estudo, de acordo com Pedreira-da-Silva (1994).

Guerra (1986) verificou, através de análise química dos diferentes tipos de rochas carbonáticas ao longo do planalto cárstico de Irecê, que não existe uma variação importante na tendência regional dos teores de $\mathrm{CaO}$ nos carbonatos, que varia entre 35 e $55 \%$ nos litotipos ocorrentes. Este autor considerou que a composição química das rochas carbonáticas não é um fator relevante na variação da distribuição e características morfológicas de feições cársticas, principalmente entre a parte sul e norte do planalto. 
O carste da área é coberto a parcialmente coberto, devido à restrita distribuição de afloramentos calcários e à presença de cobertura sedimentar e solos, na maior parte de seus setores. Segundo Ferrari (1990) a profundidade da superficie rochosa é muito irregular. O solo, descrito na ocasião como terra rosa, possui cor vermelha muito forte predominante, composição areno-argilosa e arcabouço formado por grãos remanescentes de depósitos coluvionares. Silva et al. (1981) descrevem que os solos sobre os planaltos cársticos da região são latossolos vermelho escuros eutróficos e latossolos vermelho amarelo eutróficos, ambos apresentando textura argilosa com consideráveis quantidades de quartzo (40 a 95\%).

$\mathrm{Na}$ área de estudo a espessura da cobertura sobre o epicarste pode ser delineada a partir da descrição litológica de poços artesianos. Para isso, foi elaborado o mapa de contorno da profundidade da cobertura detrítica (fig. 3.1). Este mapa contou com os dados de 43 logs de poços feitos pela Companhia de Engenharia Rural da Bahia-CERB, entre os anos de 1978 e 1995.

De acordo com a descrição litológica dos poços, os solos vermelho escuro e vermelho amarelado ocorrem no planalto carbonático, na proximidade dos vales do Rio Preto e do Riacho do Gado, apresentando espessura entre 1 e $8 \mathrm{~m}$, com média em torno de $3 \mathrm{~m}$. As coberturas sedimentares, constituídas por sedimentos areno-argilosos contendo seixos de rochas, podem alcançar espessuras entre 25 a $60 \mathrm{~m}$ na área localizada junto ao contato entre as rochas carbonáticas e não carbonáticas, em setores localizados a oeste e leste da área. No setor sudoeste da área, em volta do vale do Rio Cochó, a cobertura sedimentar e os solos formam camadas muito delgadas que revestem rochas não-carbonáticas, geralmente com espessuras inferiores a $5 \mathrm{~m}$.

A espessura da seqüência carbonática na porção centro-sul da Bacia de Irecê é superior a 400m, segundo Misi (1979). Na área, a maior parte dos poços da CERB chegam a perfurar mais de $150 \mathrm{~m}$ de rochas carbonáticas, sem alcançar a base da seqüência. No entanto, alguns poços situados próximo ao contato geológico com rochas não-carbonáticas, ao sul da área, chegam a alcançar a base da seqüência, numa profundidade de $80 \mathrm{~m}$ da superfície.

\section{Descontinuidades geológicas}

A porosidade primária em rochas muito permeáveis é considerada como um dos fatores limitantes no desenvolvimento de feições cársticas (Palmer 1984; Palmer 1991; Ford \& Williams 1989). Uma rocha muito porosa permite a atuação de fluxo intergranular, que possui caráter 


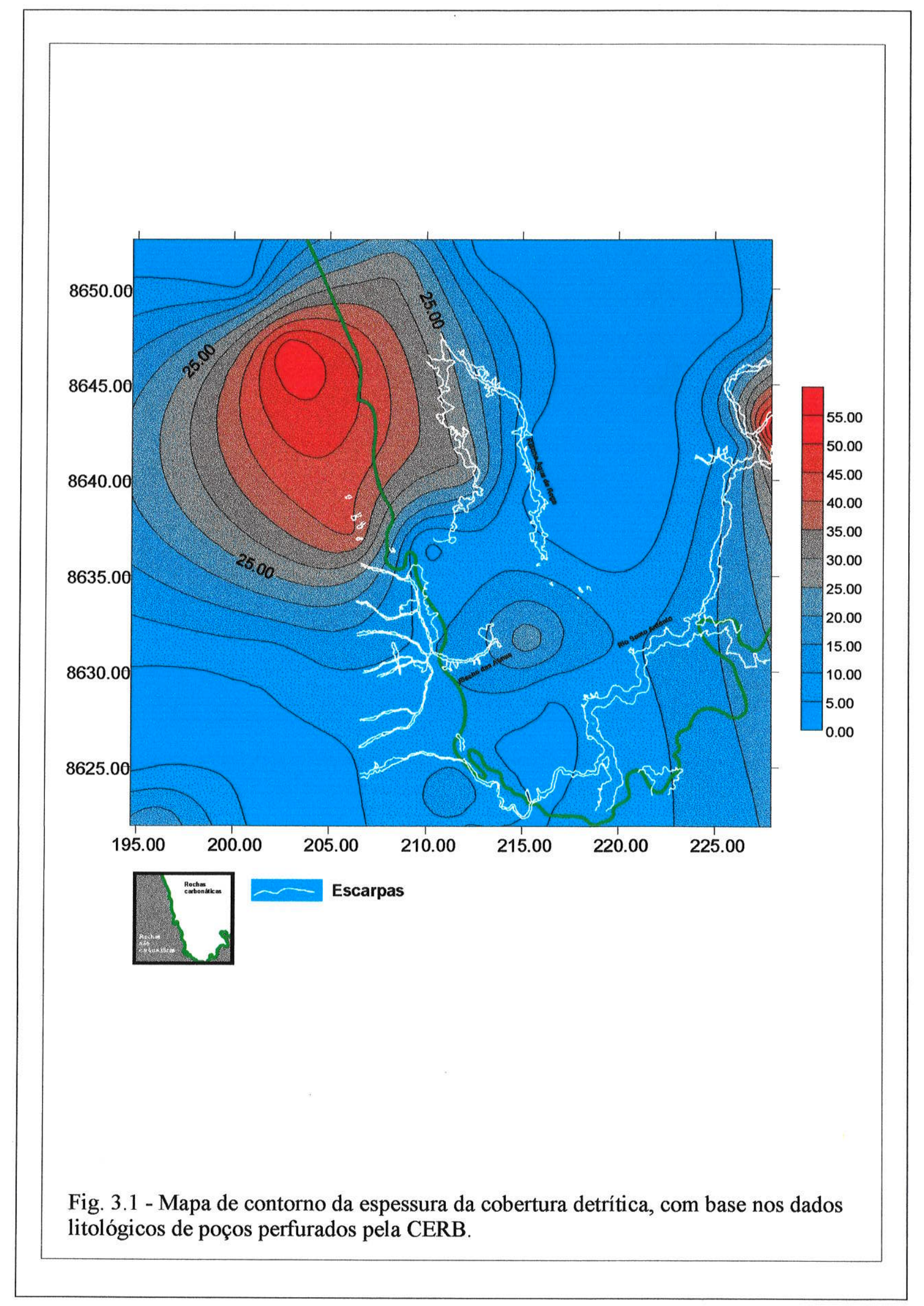


difuso, diminuindo assim, a transmissividade de água em fraturas e planos de acamamento. Em condições opostas, a canalização de fluxo em superficie e a criação do fluxo de condutos em subsuperficie é favorecida onde a porosidade secundária, representada principalmente por sistemas de juntas, falhas e planos de acamamento, é bem definida (Parizek, 1976). Desse modo, o entendimento do modo de ocorrência das estruturas geológicas torna-se muito importante.

O mapa de fotolineamentos resultou da interpretação de fotografias aéreas na escala 1:25.000 (fig. 3.2). Este mapa serviu como base cartográfica para os cálculos da densidade de comprimento de fotolineamentos por $\mathrm{km}^{2} \mathrm{e}$ orientação preferencial de fotolineamentos, feitos respectivamente através dos programas IDRISE e ROCKWARE. O mapa da densidade de comprimento de fotolineamentos foi elaborado através do programa SURFER.

Os traços de fotolineamentos correspondem, em sua maior parte, a segmentos retos correspondentes a escarpas dispostas nas bordas de depressões fechadas, vales profundos e ravinas transversais (fig. 3.2a). Considera-se, no presente trabalho, que parte dos fotolineamentos interpretados são correlacionáveis aos traços de fraturas e falhas apresentando mergulhos médios a altos. Estas estruturas são mais ressaltadas em rochas com planos de acamamento suavemente inclinados, como ocorre na área. A estrutura geral das rochas carbonáticas é caracterizada por planos de acamamento com mergulhos suaves e localmente intermediários, variando geralmente entre 5 e $15^{\circ}$. Os fotolineamentos possuem concentrações maiores no intervalo de orientação $\mathrm{N} \mathrm{a}$ N10E, seguido do intervalo N30-40W (fig.3.2b).

A densidade de fotolineamentos em áreas carbonáticas não reflete diretamente suas concentrações em determinados setores, quando há mascaramento pela presença de coberturas sedimentares (Cheema \& Islan, 1996). Assim, são mais visíveis os fotolineamentos em locais com rocha exposta e onde houve subsidência, colapso ou erosão da cobertura sedimentar e do solo. $\mathrm{O}$ mapa de densidade de fotolineamentos (fig. 3.2c), demonstra que as fraturas estão heterogeneamente distribuídas em boa parte da área, concentrando-se principalmente nos setores norte, nordeste e noroeste. $\mathrm{O}$ traçado das curvas que representam intervalos de densidade maiores que 1,80, envolvendo áreas com 1 a $2 \mathrm{~km}^{2}$, distribuídas principalmente no centro e a oeste da área. Nas porções NW e NNE do mapa, os intervalos de maior densidade envolvem áreas com extensão de 3 a $7 \mathrm{~km}^{2}$. 


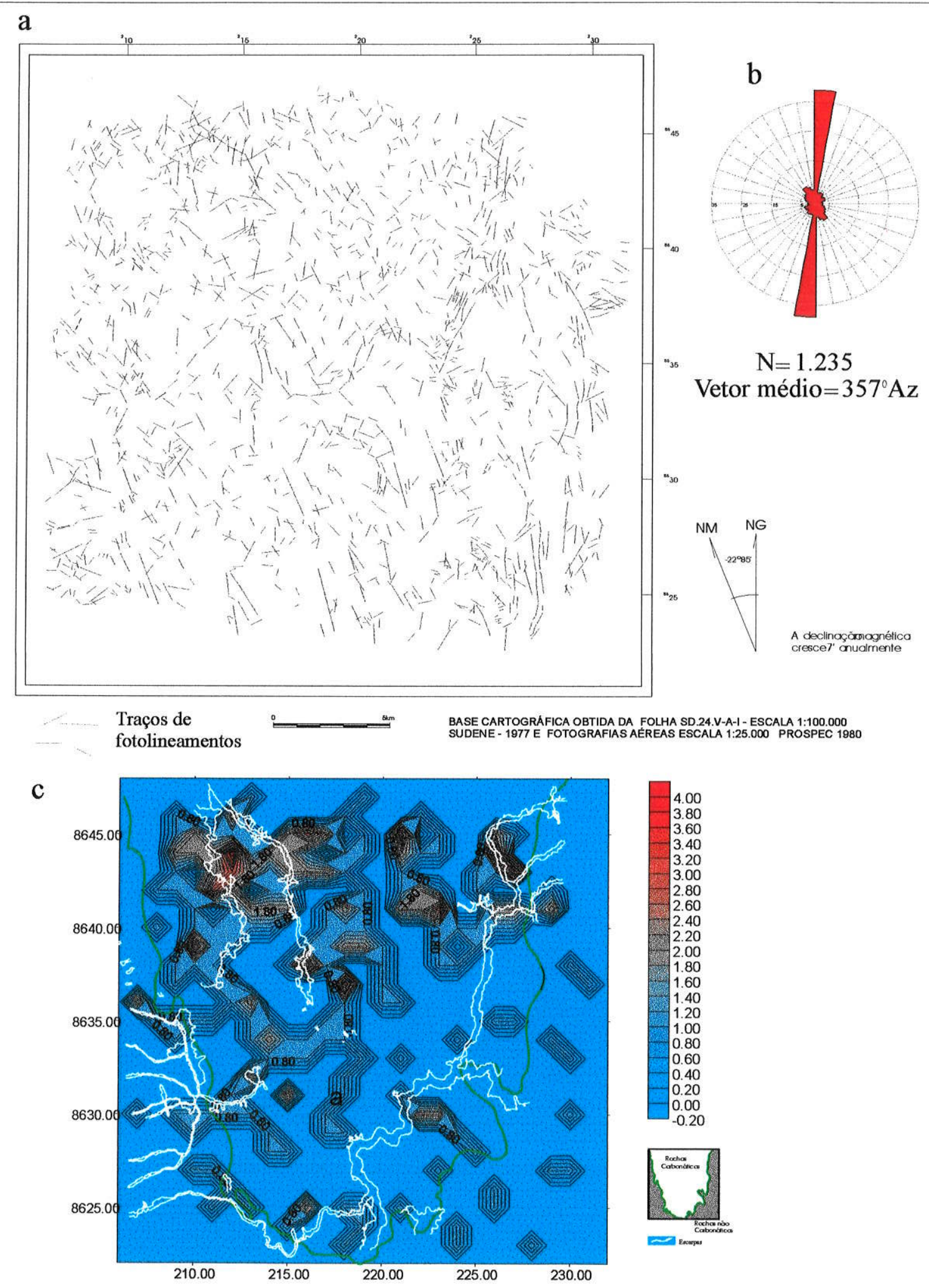

Fig. 3.2 - (a) mapa de fotolineamentos elaborado através de fotografias aéreas 1:25.000; (b) histograma de roseta da direção de fotolineamentos; (c) densidade de comprimento de fotolineamentos por malha de $1 \times 1 \mathrm{Km}$. 


\section{2 - Tipos e distribuição de feições do relevo}

Os tipos e distribuição de feições de relevo em superfície estão representados no mapa de fenômenos cársticos (Anexo 1). Este mapa foi confeccionado a partir da integração das faixas de fotografias aéreas em escala 1:25.000 (PROSPEC, 1981), referenciado segundo a carta topográfica 1:100.000 do IBGE (folha SEABRA, SD 24-V-A-I). O mapa original foi digitalizado no programa AUTOCAD, com modificações e impressão feitos a partir do programa COREL DRAW.

As feições de relevo e os tipos de drenagens na área estão sendo apresentados no referido mapa, tendo-se em conta o emprego de terminologias isentas de conotação genética. A descrição das feições presentes no mapa, leva em consideração os seguintes aspectos: 1) dimensão e forma em planta; 2) características do escoamento superficial das drenagens; 3) relação com feições cársticas em subsuperficie; 4) proximidade de contato com as rochas não carbonáticas, 5) topografia do terreno e 6 ) relação com a cobertura sedimentar local.

As formas de relevo que foram descritas são depressões fechadas, vertentes, drenagens e pontos de absorção do escoamento superficial. As feições relacionadas às ações de processos fluviais, cársticos ou mistos serão associadas com base na descrição das formas acima mencionadas, de acordo com Williams (1971, 1972), Gams (1978), Jennings (1985), White (1988), Ford \& Williams (1989) e Karmann (1994).

As vertentes representam superfícies do relevo com declividades contrastantes, associadas a escarpas ou a simples ressaltos topográficos. As vertentes escarpadas são caracterizadas pela presença de afloramentos rochosos que compõem escarpas e formam quebras abruptas do relevo, comuns nos vales das principais drenagens da área. As vertentes suaves caracterizam-se por ondulações suaves do relevo relacionadas com a erosão da cobertura sedimentar inconsolidada.

\section{Drenagens e vales associados}

As drenagens da área estão inseridas na bacia do Rio Paraguaçu, que nasce na Região da Chapada Diamantina e deságua no litoral a sul de Salvador. O Rio Santo Antônio ou Rio Preto é a principal drenagem da região e um dos principais afluentes do alto curso do Rio Paraguaçu (Anexo 1). A característica principal destas drenagens na maior parte da área consiste na ausência de uma rede contínua e organizada de canais fluviais em muitos locais na superficie, principalmente sobre as rochas carbonáticas. 
As drenagens alogênicas nascem em áreas não-carbonáticas e prosseguem o seu curso sobre as rochas cársticas, onde algumas são capturadas para subsuperficie. Os principais cursos de águas locais, a exemplo dos rios Santo Antônio e Cochó, nas porções central, sul e sudeste da área, e também os riachos do Gado, Água de Rega e das Almas, situados nas porções norte e noroeste da área, são drenagens alogênicas. Estas drenagens são caracterizadas por vales encaixados com vertentes bem definidas por escarpas de rocha, que acompanham boa parte do seu curso. O Rio São João, localizado a sudeste da área, possui curso restrito ao domínio de rochas não-carbonáticas.

O Rio Santo Antônio adentra a área pela parte sul, saindo desta pela porção centro-leste, após uma forte inflexão da direção do vale de norte-sul para leste-oeste, que direciona a drenagem para as serras de arenito, onde ocorrem canais em gargantas. $O$ seu vale é plano, possui largura variando entre 350 e $800 \mathrm{~m}$ e é revestido por sedimentos aluvionares. O canal do rio é somente definido a partir do entroncamento com o Rio Cochó na parte sul da área, onde adquire um curso perene alimentado pelo Rio Cochó e por várias resurgências cársticas dispostas ao longo de suas margens. No vale são observados lagos e represamentos naturais de água, sendo que alguns dos lagos estão relacionados diretamente com a presença de resurgências. Pequenas depressões cársticas drenadas por lagos ou mesmo secas, são observadas junto ao entroncamento com o Riacho do Gado.

O Riacho do Gado é uma drenagem intermitente proveniente das serras de arenito a nordeste da área e caracteriza-se por vales também com fundo plano e revestidos por sedimento, onde não se observam canais bem definidos. Pequenas depressões cársticas podem ser observadas ao longo do seu vale, que é um pouco mais estreito do que o vale do Rio Santo Antônio.

Os riachos Água de Rega e das Almas, situados nas partes oeste e noroeste da área, são caracterizados por vales que nascem nas serras areniticas e terminam sobre a superficie carbonática, sendo considerados vales cegos. O Riacho Água de Rega extende-se por mais de $15 \mathrm{~km}$ na área terminando junto a caverna Lapa Doce. Já o Riacho das Almas perfaz um trajeto curto sobre as rochas carbonáticas de cerca de $3,5 \mathrm{~km}$, terminando na caverna Alto da Cruz. Os pontos de junção dos vales cegos com as galerias de cavernas, aproximadamente no mesmo nível topográfico são considerados paleosumidouros de drenagem. Os cursos de água nestes vales são praticamente inexistentes ao longo de todo o percurso sobre as rochas carbonáticas. Estes vales são somente banhados em anos muitos chuvosos, de acordo com relatos da população local. 
Os vales secos referem-se a pequenos cursos de drenagens atualmente abandonados, de ampla ocorrência no domínio das rochas carbonáticas (Anexo 1). Uma parte considerável de vales secos estão associados com drenagens autogênicas, as quais possuem curso restrito ao planalto cárstico. As drenagens são geralmente dendríticas e também centrípetas, convergindo para pontos de absorções situados nos fundos de depressões e vales das drenagens maiores.

\section{Poljes}

Certas vertentes escarpadas correspondem a paredões quilométricos, associados a pequenas bacias de sedimentos aluvionares com fundo suavemente inclinado. $\mathrm{Na}$ base dos paredões ocorrem, depressões fechadas e pontos de absorção de pequenas drenagens. Estes conjuntos de feições de relevo podem ser encontradas nas proximidades do contato geológico entre a rochas carbonáticas e não-carbonáticas, a noroeste da área e também próximo ao vale do Rio Santo Antônio e da BR-242, a sul. As características descritas para o conjunto de feições preenchem os requisitos necessários para classificá-las como poljes de acordo com Gams (1978).

Os paredões com direção geral NW-SE que ocorrem a noroeste da área (Anexo 1), estão relacionados a um polje de contato, devido a sua proximidade do contato geológico com as rochas não-carbonáticas, de acordo com a classificação de Gams (op. cit.). Este polje é constituido por uma escarpa com aproximadamente $11 \mathrm{~km}$, numa única face, inclinada para oeste, exibindo traçado irregular, acompanhando a direção do contato geológico. As escarpas podem alcançar até $60 \mathrm{~m}$ de altura, de acordo com a carta topográfica 1:100.000, e geralmente são bordejadas por sedimentos aluvionares e coluvionares, que formam estreitas bacias ocupadas por depressões fechadas e pontos de absorção, com seus limites situados entre as escarpas e as vertentes suaves. Ford \& Williams (1989) descrevem que os poljes de contato representam uma tentativa de desenvolvimento de vales cegos por drenagens mais modestas, que teriam infiltrado preferencialmente na zona de contato geológico. A distância atual do traçado da escarpa, que demarca o polje e o contato geológico pode chegar a $5 \mathrm{~km}$ em alguns locais. Isto pode ser devido à retração da encosta carbonática, induzidas por colapso de cavernas na sua base (Karmann, 1994) ou corrosão lateral sobre a cobertura sedimentar impermeável (Gams, 1978). Nota-se que o traçado destas encostas tende a engolfar-se em diversos pontos onde ocorrem dolinas, sugerindo o seu recuo com o tempo. 
O polje a sul é caracterizado por paredões escarpados com direções E-W e NE-SW que têm na sua base, um conjunto de expressivas depressões fechadas com diâmetros variando entre 150 e $300 \mathrm{~m}$, formadas sobre a cobertura sedimentar (Anexo 1). Esta cobertura forma uma pequena bacia situada entre uma vertente suave e as escarpas. A formação deste polje está provavelmente relacionada a proximidade do Rio Santo Antônio, que dista cerca de $2 \mathrm{~km}$ das suas vertentes. Esta feição é semelhante a poljes do nível de base (baselevel poljes), de acordo com Gams (1978) e Ford \& Williams (1989), que são desenvolvidas onde o lençol freático intercepta a superficie em periodos de cheias, controlados por exemplo, pela subida do nivel de um rio próximo. A presença do lençol freático pode ser correlacionada a alagamentos observados na base de algumas das depressões fechadas locais, a partir de fotografias aéreas. Em épocas de cheias, os alagamentos na área deste polje são constantes, segundo Aloisio Cardoso (Centro de Recursos Ambientais-BA, informação verbal, 1997).

\section{Depressões fechadas}

As depressões fechadas são as formas mais freqüentes na área e sobressaem-se no relevo por sua ocorrência em grande número, ao longo de toda a área. O relevo local corresponde assim a um carste de dolinas, em referência ao termo inglês doline karst (Jennings, 1985; White, 1988). Este tipo de paisagem é considerada comum em áreas cársticas, sendo bem desenvolvidas em seqüências carbonáticas de baixo mergulho predominante, como é o caso da área.

A representação destas feições no mapa (Anexo 1) é feita utilizando a designação de depressões fechadas exibindo perfil suave ou escarpado. A profundidade da depressão e a presença de escarpas em rocha carbonática são os elementos chaves utilizados na distinção destes dois tipos de depressões fechadas na aerofotointerpretação. O primeiro tipo de depressão, mais raso, possui profundidades estimadas em menos de $10 \mathrm{~m}$ (de acordo observações de campo) e bordas definidas por leves ressaltos topográficos em material da cobertura (fig. 3.3). O outro tipo consiste de depressões mais profundas, caracterizadas por escarpas em rocha envolvendo, parcialmente ou totalmente suas bordas, e profundidade que pode ultrapassar $40 \mathrm{~m}$ em alguns locais (fig. 3.4).

As depressões presentes são consideradas dolinas simples ou mesmo uvalas, quando houver coalescência de várias dolinas simples, a depender da dimensão relacionada. 


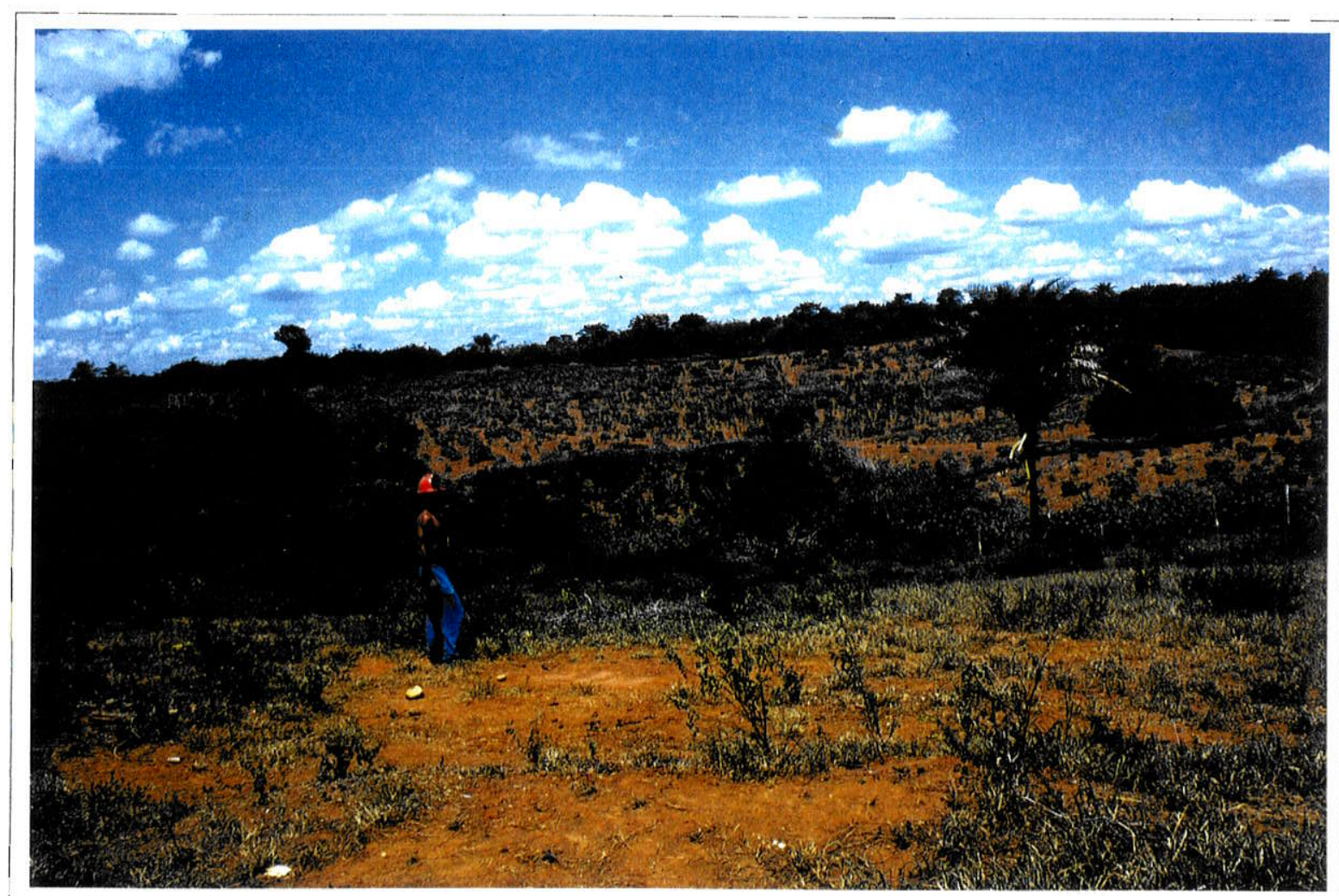

Fig. 3.3 - Depressão fechada com perfil suave, situada na porção sul da área em estudo Foto do autor.

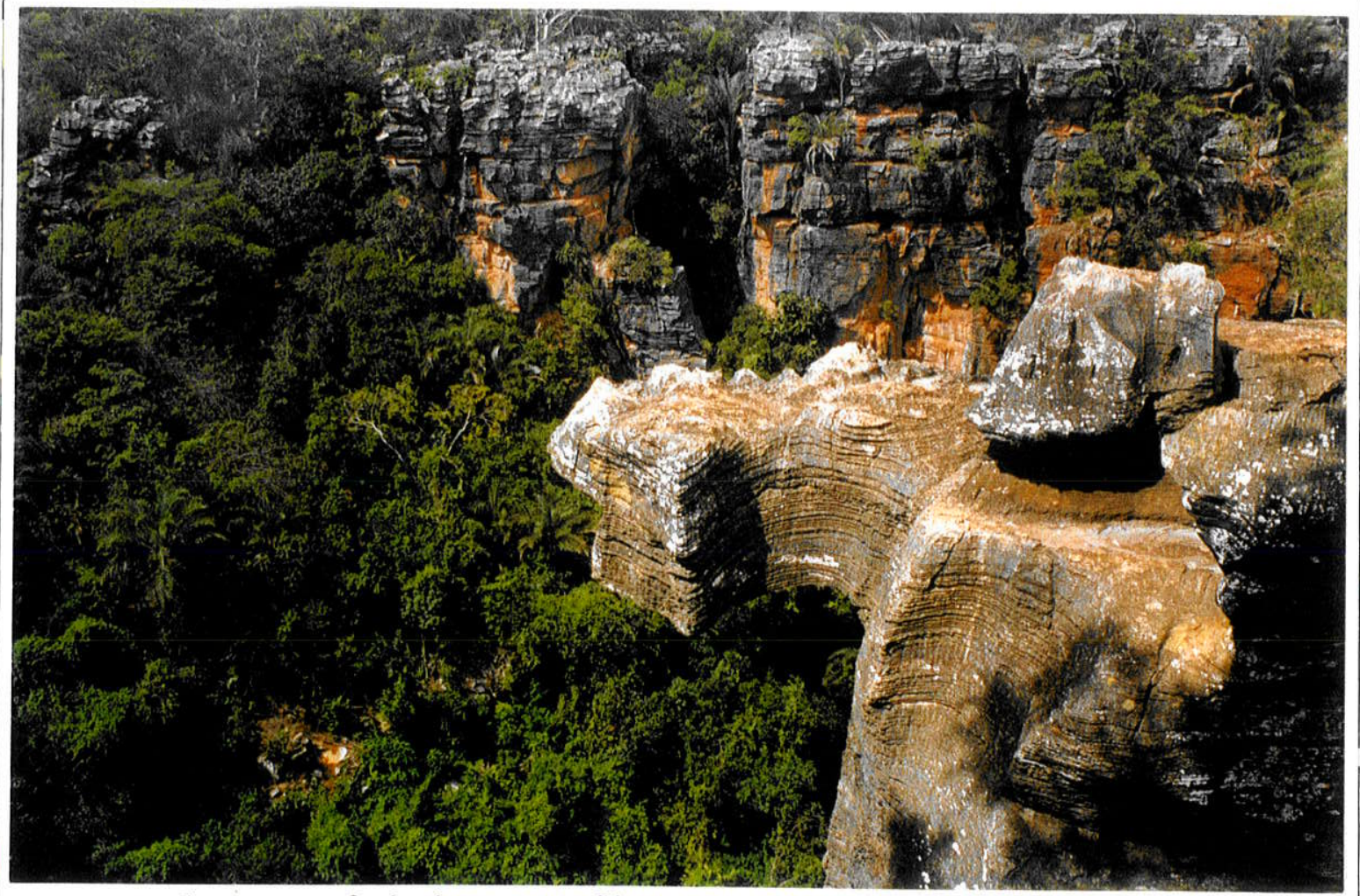

Fig. 3.4 - ] Depressão fechada com perfil escarpado, situada entre as cavernas Lapa Doce I e II, no Sistema Lapa Doce. Foto do autor. 
As depressões fechadas com perfis suaves assemelham-se a dolinas de subsidência lenta (drawdown dolines; Williams, 1983), formadas pela remoção e infiltração de sedimento da cobertura através de estruturas geológicas e condutos situados na zona superficial do carste ou zona epicárstica. Elas são rasas e possuem perfis caracterizados por mergulhos mais uniformes e suaves.

As depressões fechadas com perfil escarpado podem ser correlacionadas a dois tipos de dolinas: as de colapso e as aluvionares. As dolinas de colapso estão relacionadas a desabamento do teto de cavernas, sendo comum apresentarem encostas verticalizadas e contorno irregular em planta, como também profundidades maiores, podendo ser facilmente distinguidas em fotografias aéreas. As dolinas aluvionares (Cramer 1941 apud Jennings, 1985; Soriano \& Simón, 1995) caracterizam-se pela presença de pequenos ramos de drenagem ou cones de escoamento de água sobre a cobertura sedimentar que terminam em sumidouros, situados na base de escarpas em poljes, onde os sedimentos são removidos para dentro de condutos.

\section{3 - Morfometria de feições cársticas}

A análise morfométrica tem como objetivo produzir uma descrição quantitativa do relevo cárstico e abstrair o aspecto subjetivo da classificação qualitativa e genética (Karmann, 1994). No presente trabalho, foram utilizadas algumas técnicas para obtenção de índices morfométricos, que visam caracterizar parâmetros planimétricos da distribuição, forma, orientação e área superficial de feições cársticas.

O método de análise tem, como base, técnicas de geoprocessamento aplicadas por Ferrari et al. (1997) e também medições feitas diretamente sobre o mapa de fenômenos cársticos. O geoprocessamento consiste, a princípio, na utilização dos dados digitalizados do mapa de fenômenos cársticos (Anexo 1), a partir do programa AUTOCAD. Os dados produzidos nesta etapa foram exportados para o programa IDRISI, onde foi gerada uma malha referenciada por coordenadas UTMs, contendo as imagens das feições cársticas a serem analisadas. Por este último programa também foram extraidas planilhas de dados sobre área, perímetro e circularidade de depressões fechadas. 
Os principais parâmetros considerados neste trabalho foram: a densidade de depressões, orientação de dolinas e razão entre a sua largura e comprimento, área e perímetro de depressões, índice e razão de dolinamento; indice de circularidade de depressões e densidade de sumidouros autogênicos. Estes parâmetros são fortemente dependentes da escala do levantamento fotogeológico, que no caso é 1:25.000, pois conforme a escala seja ampliada, depressões menores tornam-se demarcáveis (Karmann, 1994).

A área da superficie carbonática considerada nos cálculos está representada na figura 3.5. Comparou-se os parâmetros obtidos nas porções norte e sul da área, a partir da coordenada UTM $8635 \mathrm{~N}$.

Para calcular os índices descritos a seguir, agrupou-se as depressões fechadas em conjuntos provavelmente associados ao mesmo processo genético seguindo recomendações de Bondesan et al. (1992). Assim, foram obtidos os índices para as depressões fechadas apresentando perfil suave e perfil escarpado, quando possível, separadamente nos setores norte e sul da área. A comparação entre os setores baseia-se no fato das cavernas caracterizadas por extensos e amplos condutos ocorrerem preferencialmente nas porções centro e sul da área, situadas nas proximidades do Rio Santo Antônio. Os índices de cada setor são comparados entre si e com os índices produzidos para a população geral de depressões, com o objetivo de compartimentar a área cárstica estudada em função da morfologia destas feições morfológicas.'

\section{Densidade de depressões fechadas}

Corresponde ao número de depressões cársticas por unidade de área $\mathrm{em}^{\mathrm{km}}{ }^{2}$ (tabela 3.1). Este parâmetro é um importante fator para ser correlacionado entre diferentes setores de uma área cárstica ou entre áreas cársticas, mesmo com domínios morfoclimáticos distintos, principalmente quando associado a outros parâmetros morfométricos (Day, 1976).

As depressões com perfil suave estão em maioria na área, sendo que elas compõem cerca de $94,7 \%$ do total de depressões medidas no setor norte e $80,4 \%$ do total de depressões medidas no setor sul. $O$ restante das depressões medidas é do tipo com perfil escarpado, possuindo ocorrência mais ampla no setor sul e mais restrita no setor norte. A densidade de depressões nos setores norte e sul não difere muito considerando a população geral de depressões e, em particular, as depressões de perfil suave. Entretanto, a densidade de depressões escarpadas é aproximadamente quatro vezes maior na parte sul da área. 


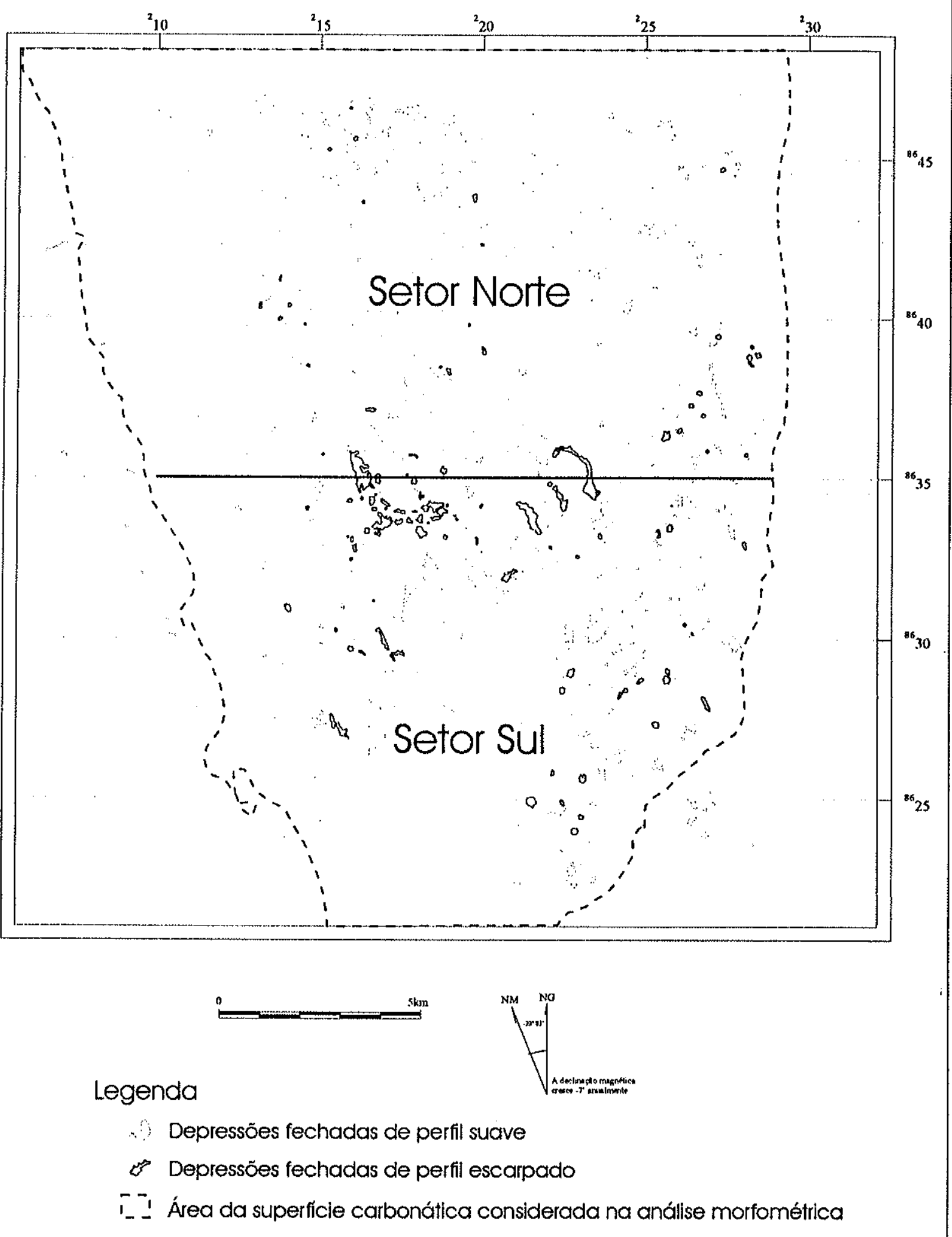

Fig. 3.5 - Setores da superfície carbonática considerados na análise morfométrica. 


\begin{tabular}{|c|c|c|c|c|}
\hline SETOR & Tipo de depressão & $\mathrm{N}^{\mathrm{Q}} \mathrm{de}$ depressõcs $\left(\mathrm{N}_{\mathrm{d}}\right)$ & $\begin{array}{c}\text { Arca supcrficial }\left(A_{K}\right) \\
\left(\mathrm{Km}^{2}\right)\end{array}$ & Densid. de dolinas (Dd) \\
\hline NORTE & perfil suave & 358 & 276,41 & 1,29 \\
\hline NORTE & perfil escarpado & 30 & 276,41 & 0,11 \\
\hline NORTE & lotal & 378 & 276,41 & 1,37 \\
\hline SUL, & perfil suave & 361 & 215,97 & 1,67 \\
\hline sut, & perfil escarpado & 88 & 215,97 & 0,40 \\
\hline SUL & total & 449 & 215,97 & 2,08 \\
\hline AREA GERAL & Lotal & 827 & 492,38 & 1,68 \\
\hline
\end{tabular}

Tabela 3.1: Densidade de depressões cársticas

\section{Área superficial e perímetro de depressões}

A área planimétrica e o perímetro de todas as depressões foram medidos através do programa IDRISI, gerada com a imagem de dolinas com resolução $25 \times 25 \mathrm{~m}$ (tabela 3.2 ). A área planimétrica das depressões é consideravelmente maior no setor sul que também possui maior densidade de dolinas com perfil escarpado, do que no setor norte.

A área planimétrica média dos dois tipos de depressões em questão foi comparada no setor sul, obtendo-se valores para as depressões do tipo escarpado maiores que o dobro do valores obtidos para as depressões com perfil suave. Ainda no setor sul, foi verificado que a área planimétrica correspondente ao somatório das depressões com perfil escarpado é $65 \%$ maior do que o valor referente as depressões com perfil suave, apesar delas representarem apenas $19,6 \%$ das depressões medidas neste setor.

A variação nos valores dos perímetros médios entre os setores e os diferentes tipos de depressões acompanha as tendências relacionadas aos valores referidos de área superficial média (tabela 3.2). Os perímetros médios de depressões com perfil escarpado no setor sul são consideravelmente maiores do que os apresentados pelas depressões de perfil suave, assim como acontece com a área planimétrica das depressões.

Nota-se que o perimetro médio varia entre quase $1 \mathrm{~km} \mathrm{e} 0,57 \mathrm{~km}$ ao longo da área, indicando depressões com grandes dimensões. O perímetro máximo é $10,189 \mathrm{~km}$ e o mínimo possui $0,099 \mathrm{~km}$. Este resultado está limitado à observação em escala 1:25.000. Na realidade, existem depressões menores observadas em campo, inclusive no interior das maiores, não resgatadas nesta escala de trabalho. 


\begin{tabular}{|c|c|c|c|c|}
\hline SETOR & Tipo de depressão & Área média $\left(\mathrm{Km}^{2}\right)$ & $\sum$ áreas de dolinas $\left(\mathrm{Km}^{2}\right)$ & Perímetro médio $(\mathrm{Km})$ \\
\hline NORTE: & total $(n=378)$ & 0,01 & 5,59 & 0,57 \\
\hline SUL. & suave $(n=361)$ & 0,01 & 2,96 & 0,57 \\
\hline sul, & escarpado $(n=88)$ & 0,03 & 5,48 & 0,96 \\
\hline SUL. & Lotal $(n=449)$ & 0,02 & 8,44 & 0,65 \\
\hline AREA GISRAL. & total $(n=827)$ & 0,02 & 14,03 & 0,61 \\
\hline
\end{tabular}

Tabela 3.2 - Área e perímetro das depressões fechadas

O gráfico área x perímetro (fig. 3.6) demonstra um alto índice de correlação entre estes dois parâmetros e sugere que a maior parte das depressões possui contornos com poucas irregularidades, ou pouco rugosos. Um menor número de depressões com áreas planimétricas superiores a $0,13 \mathrm{Km}^{2}$ possuem perímetros consideravelmente maiores, provavelmente devido a irregularidades nos seus contornos. A mesma relação, foi verificada por Sauro (1991), numa área cárstica situada no sul da Itália.

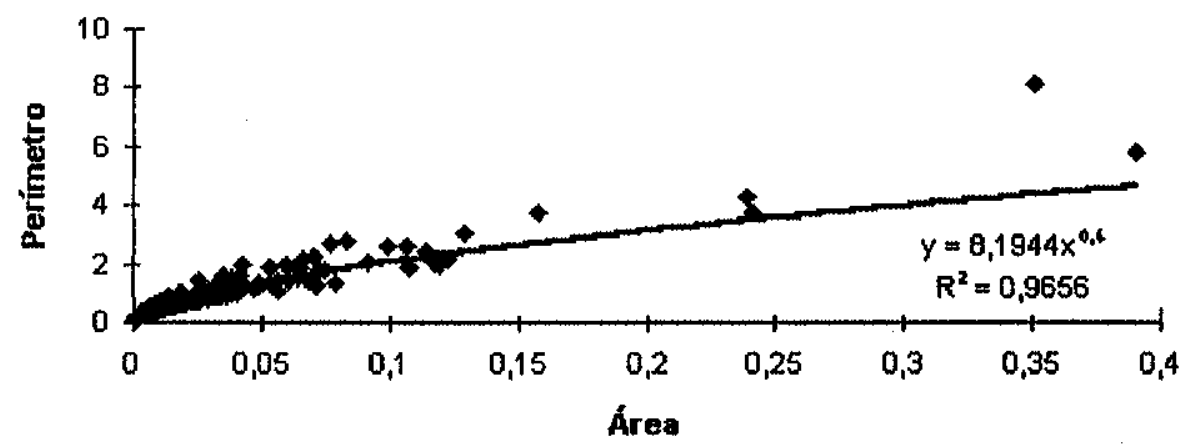

Fig. 3.6 - Gráfico de correlação entre área planimétrica e perímetro das depressões fechadas

\section{Densidade de área planimétrica}

Os setores apresentando diferentes densidades de área superficial de depressões por $\mathrm{km}^{2}$ estão representados no mapa de densidade de área superficial medida em malhas de $1 \times 1 \mathrm{~km}$ (fig. 3.7). O mapa tem como objetivo, indicar prováveis locais que apresentam maiores concentrações de depressões fechadas simples e depressões fechadas compostas. As depressões do tipo simples, por definição, tendem naturalmente apresentar áreas planimétricas menores, comparadas com as do tipo compostas, que são formadas pela coalescência de várias depressões simples.

Os locais com menores densidades de área superficial correspondem aos intervalos de 0 a $0,025 \mathrm{~km}^{2}$ e 0,025 a $0,05 \mathrm{~km}^{2}$, que estão relacionados a ocorrência de pequenas depressões, a exemplo do setor norte. Nos locais com maiores densidades de área superficial, representados por intervalos maiores que $0,075 \mathrm{~km}^{2}$, são aqueles associados a grandes depressð̃es, como ocorre na parte central da área. Ressalta-se que na parte sul da área, o mesmo cálculo de densidade não abrangeu as depressões de perfil suave. 


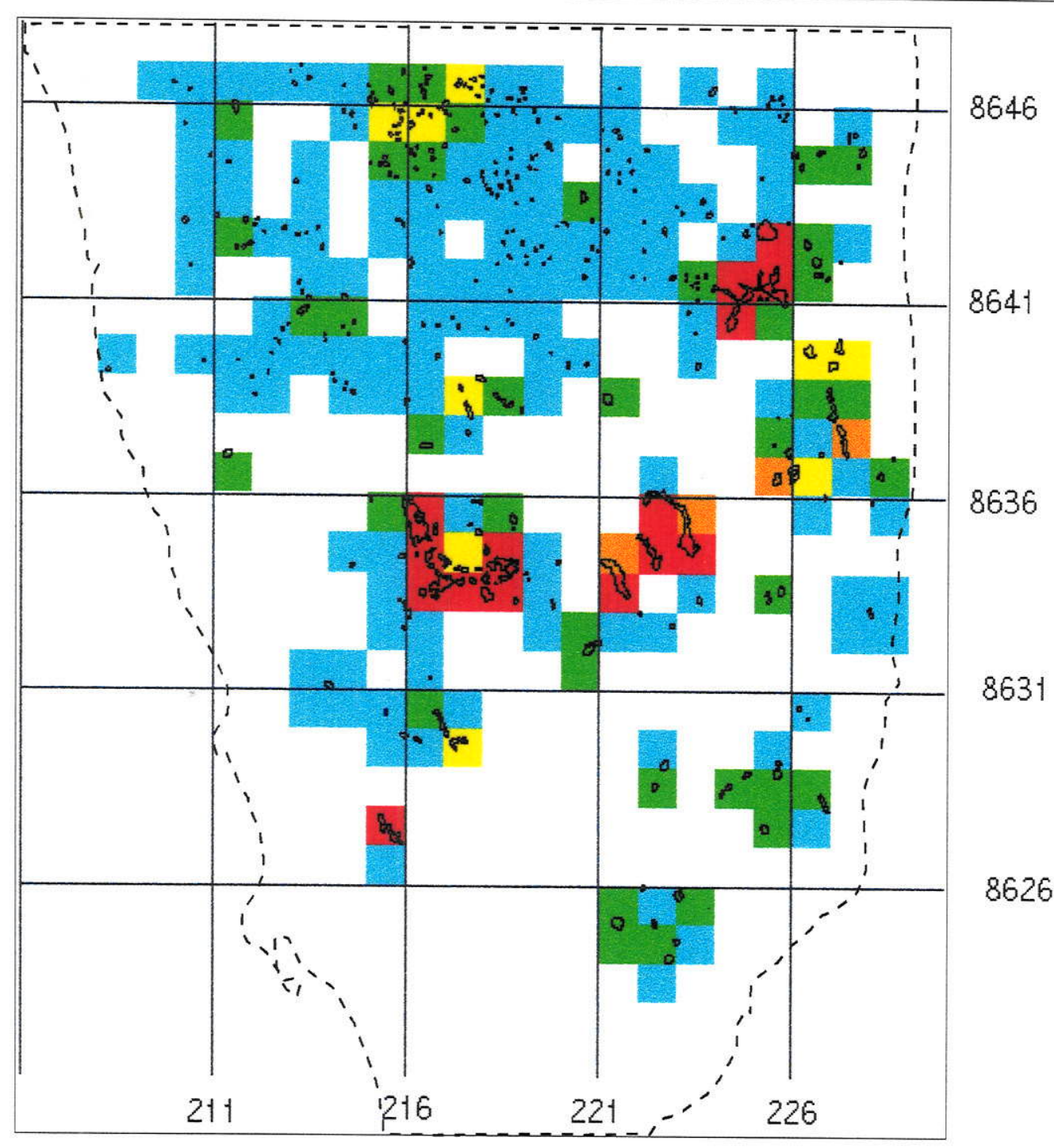

Densidade de dolinas Suaves e abruptas

$\begin{array}{ll}\square & \text { trecho sem medição } \\ \square \quad 0 \quad \text { a } 0,025 \\ \square & 0,025 \text { a } 0,05 \\ \square & 0,05 \text { a } 0,075 \\ \square & 0,075 \text { a } 0.1 \\ \square \quad \text { Maior que } 0,1\end{array}$

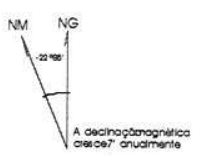

Legenda

S3 Depressões fechadas de perfil suave

- - - Área da superfície carbonática

Fig. 3.7 - Mapa de densidade de área de depressões fechadas em malha de 1x 1Km. 


\section{Índice de dolinamento e razão de dolinamento}

A somatória da área planimétrica ocupada pelas depressões cársticas é $14,03 \mathrm{~km}^{2}$, o que representa cerca de $2,84 \%$ da área carbonática, que mede $492,38 \mathrm{~km}^{2}$. Assim, apesar da existência de um expressivo número de depressões fechadas, a área planimétrica ocupada é pequena.

$O$ indice de dolinamento é determinado pela razão entre o somatório da área da superficie carbonática e a área da superficie ocupada pelas depressões, resultando num índice adimensional (tabela 3.3). No caso de locais com relevo poligonal bem desenvolvido, este índices possuem valores que tendem a 1 , segundo Williams (1972).

A razão de dolinamento é o inverso do indice de dolinamento, e tende a 0 quando a área planimétrica ocupada pelas depressões for muito inferior a área da superficie carbonática, no caso de relevos cársticos pouco desenvolvidos.

\begin{tabular}{|c|c|c|c|c|c|}
\hline SETOR & Tipo de depressð̃o & $\begin{array}{c}\text { Arca de } \\
\text { superficie }\left(\mathrm{Km}^{2}\right)\end{array}$ & $\begin{array}{c}\sum \text { das áreas de } \\
\text { depress } \sigma c s\left(\mathrm{Km}^{2}\right)\end{array}$ & $\begin{array}{c}\text { ID - Indice de } \\
\text { dolinamento }\end{array}$ & $\begin{array}{c}\text { RD -Razão de } \\
\text { dolinamento }\end{array}$ \\
\hline NORTE & total $(n=378)$ & 276,41 & 5,59 & 49,41 & 0,02 \\
\hline SUL. & suave $(n=361)$ & 215,97 & 2,96 & 73,04 & 0,01 \\
\hline SUL & escarpado $(n=88)$ & 215,97 & 5,48 & 39,41 & 0,03 \\
\hline SUL & total $(n=449)$ & 215,97 & 8,44 & 25,59 & 0,04 \\
\hline AREA GERAL & total $(n=827)$ & 492,38 & 14,03 & 35,08 & 0,03 \\
\hline
\end{tabular}

ID = área de superficie $/ \Sigma$ das áreas de depressões $\mathrm{RD}=\Sigma$ das áreas de depressões / área de superficie

Tabela 3.3 - Razão de dolinamento e indice de dolinamento

\section{Orientação de depressões fechadas e razão entre suas larguras e comprimentos}

A análise da orientação axial e forma planimétrica das depressões utilizou-se das medidas de azimute e comprimento do eixo maior das depressões e também da largura máxima perpendicular ao eixo maior medidos em 245 depressões situadas ao centro e a sul da área e também em três subáreas (tabela 3.4). As orientações preferenciais dos eixos são estabelecidas através da confeç̧ão de diagramas de rosetas utilizando o programa ROCKWARE e histogramas de barras utilizando o programa ORIGIN.

Os eixos maiores considerados nas medições estão alinhados em relação às paredes das depressões. Este alinhamento é definido aqui como sendo o ângulo entre o referido eixo e as paredes das depressões. Se o ângulo for inferior a $10^{\circ}$, considera-se que o eixo maior é bem definido na depressão e assim pode ser considerado no levantamento. As demais depressões apresentam eixo maior com ângulos superiores a $10^{\circ} \mathrm{em}$ relação as suas paredes ou possuem forma subcircular a circular e portanto não são consideradas no levantamento. 
As subáreas foram selecionadas arbitrariamente tendo em vista comparar possíveis mudanças no alinhamento das depressões devida a orientação dos condutos e fotolineamentos. Os condutos possuem direção geral variando entre $\mathrm{N}$ e N40W (fig. 2.3) e os fotolineamentos estão preferencialmente orientados no intervalo $\mathrm{N}$ a N10E (vetor médio, $357^{\circ} \mathrm{Az}$ ).

A maior freqüência de direções de eixos de depressões situam-se entre os intervalos $\mathrm{N} 30 \mathrm{~W}$ a $\mathrm{N} 30 \mathrm{E}$, com concentrações preferenciais entre $\mathrm{N} 20-30^{\circ} \mathrm{E}$ (fig. 3.8a). A variação nas atitudes ao longo da área, é verificada para 3 subáreas selecionadas. A subárea 1 apresenta freqüências de direções com concentrações principais entre N10-20E e secundárias entre N1030W e N20-30E (fig.3.8b). A subárea 2 apresenta predomínio de eixos orientados entre $\mathrm{N}$ a N10W e N10-20W (fig.3.8c). A subárea 3 apresenta concentrações preferencialmente entre N20 $30^{\circ} \mathrm{E}$ e secundariamente entre $\mathrm{N} 10-30^{\circ} \mathrm{W}$ (fig.3.8d).

Assim, com base nos intervalos de direção dos histogramas e seus vetores médios, pode-se inferir uma correlação entre a distribuição do eixo maior de dolinas com os dados de fotolineamentos e de galerias de cavernas. As subáreas 2 e 3, com predominância de intervalos NW-SE, possuem supostamente uma maior relação com a direção geral das galerias do que a subárea 1, onde predomina eixos NE-SW.

A razão comprimento/largura de depressões caracteriza o grau de desenvolvimento linear na forma planimétrica das depressões (Kemmerly, 1976). A largura considerada aqui, é a largura máxima normal ao eixo maior medido. As razões obtidas variam entre 0,115 a 0,954 , sendo o maior números de observações concentradas nos intervalos com razões 0,3-0,4 a 0,6-0,7 (fig. 3.8e). Isto sugere a existência de dois grupos distintos de depressões: um deles caracterizado por razões entre 0,2 e 0,5 que indicam tendências de formas mais lineares, e outro grupo caracterizado por razões entre 0,5 a 0,9 , que indicam tendências de formas mais circulares. Estas mesmas relações persistem nas três subáreas em questão (fig. $3.8 \mathrm{f}, \mathrm{g}, \mathrm{h}$ ).

A frequêencia de comprimento de eixo maior de dolinas, refere-se ao percentual de comprimento a cada intervalo de $10^{\circ} \mathrm{Az}$ (tabela 3.4). Os intervalos com maiores freqüências encontrados variam de $\mathrm{N} 30 \mathrm{~W}$ a N30E, concordando com os intervalos dos referidos histogramas de direção. Os intervalos com orientações preferenciais são N a N10W e N10W-N20W, seguidos pelos intervalos N20-30W e N20-30E. 


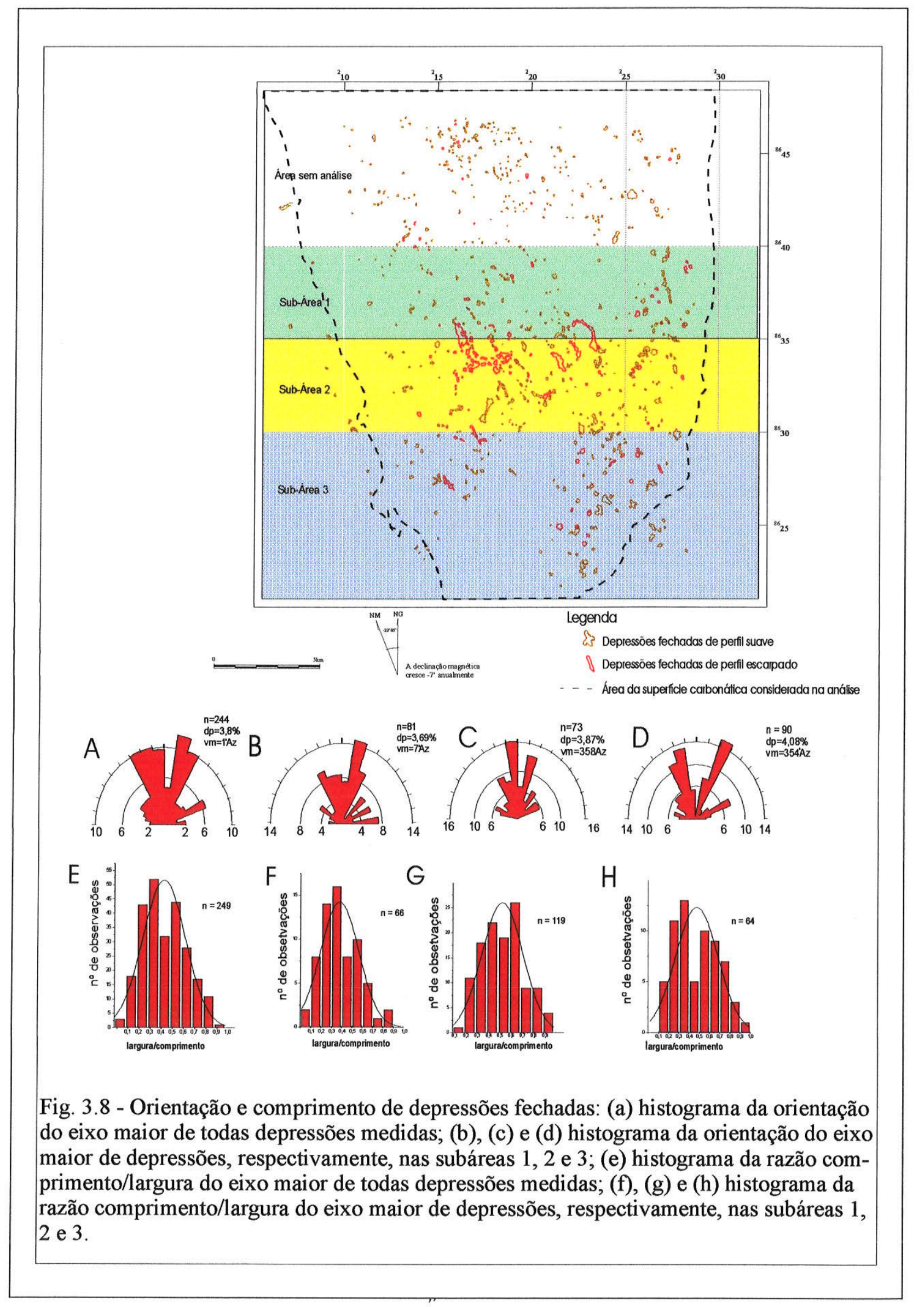




\begin{tabular}{|c|c|c|c|}
\hline $\begin{array}{l}\text { INTERVALOS DE RUMOS } \\
\text { (GRAUS) }\end{array}$ & $\begin{array}{l}\Sigma \text { DO COMPRIMENTO DE EIXO } \\
\text { A CADA INIERVALO (KM) }\end{array}$ & $\begin{array}{l}\text { FREQUUENCIA DE COMPRIMENTO } \\
(\%)\end{array}$ & $\begin{array}{c}N^{\circ} \text { DE OBSERVAÇÓES EM CADA } \\
\text { INIERVALO }\end{array}$ \\
\hline $1-10 \mathrm{E}$ & 2,73 & 4,16 & 13 \\
\hline $11-20 \mathrm{E}$ & 4,83 & 7,37 & 23 \\
\hline $21-30 \mathrm{E}$ & 7,59 & 11,58 & 23 \\
\hline $31-40 \mathrm{E}$ & 0,78 & 1,19 & 5 \\
\hline $41-50 \mathrm{E}$ & 1,4 & 2,13 & 8 \\
\hline $51-60 \mathrm{E}$ & 1,54 & 2,35 & 7 \\
\hline $61-70 \mathrm{E}$ & 2,94 & 4,48 & 12 \\
\hline $71-80 \mathrm{E}$ & 2,35 & 3,58 & 8 \\
\hline $81.90 \mathrm{E}$ & 1,45 & 2,28 & 5 \\
\hline $80-89 \mathrm{~W}$ & 0,93 & 1,41 & 4 \\
\hline $70-79 \mathrm{~W}$ & 1,92 & 2,93 & 9 \\
\hline $60-69 \mathrm{~W}$ & 1,8 & 2,74 & 6 \\
\hline $50-59 \mathrm{~W}$ & 4,2 & 6,42 & 11 \\
\hline $40-49 \mathrm{~W}$ & 2,49 & 3,8 & 10 \\
\hline $30-39 \mathrm{~W}$ & 3,2 & 4,88 & 13 \\
\hline $20.29 \mathrm{~W}$ & 7,67 & 11,7 & 23 \\
\hline $10-19 \mathrm{~W}$ & 8,87 & 13,54 & 25 \\
\hline $9 \mathrm{aN}$ & 8,81 & 13,45 & 40 \\
\hline & $65,5 \mathrm{~km}$ & $100 \%$ & 245 \\
\hline
\end{tabular}

Tabela 3.4 - Dados da orientação e comprimento do eixo maior de depressões medidos no Setor Sul da área.

As relação alométrica, entre a largura e o comprimento do eixo maior das depressões foi descrita por Kemmerly (1976) e Palmquist (1979). Este parâmetro indica a tendência de uma depressão manter a mesma forma com o seu aumento de tamanho, que é melhor verificada segundo estes autores através de função potencial: (1) $\mathrm{C}=\mathrm{bL}^{\mathrm{a}}$, onde $\mathrm{C}$ e $\mathrm{L}$ representam respectivamente o comprimento do eixo maior e a largura máxima, a e b, representam constantes.

Altos índices de correlação indicam que populações de pequenas e grandes dolinas seguem - mesmo padrão e, portanto, tendem a ser condicionadas por processos morfológicos semelhantes. Baixos índices de correlação, por sua vez, sugerem diferentes populações de depressões ou controle morfológico não evidente.

A função potencial calculada para todas as depressões medidas é: $(2) \mathrm{C}=10,844 \mathrm{~L}^{0,662}$ $\mathrm{R}^{2}=0,51$

A equação (2) sugere que os dados de C e L representam uma relação alométrica fraca, pois não foi obtido um alto índice de correlação (fig.3.9). Isto é devido provavelmente a relevante quantidade de depressões aproximadamente isométricas, incluidas na população geral de depressões. 


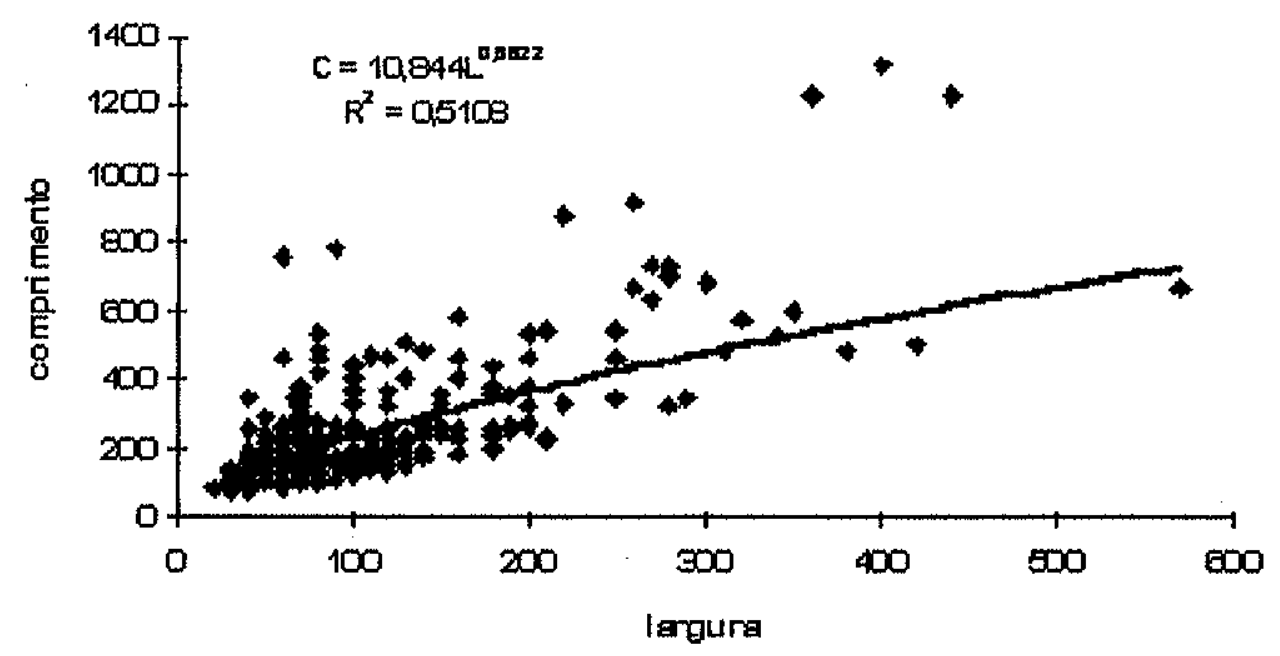

Fig. 3.9 - Gráfico da relação alométrica entre o comprimento e largura do eixo maior de depressões fechadas

\section{Índice de circularidade de depressões fechadas}

Este parâmetro, já vem sendo utilizado em outras áreas cársticas brasileiras, a exemplo do carste do Vale do Ribeira, no Estado de São Paulo (Ferrari et al.,1997).

$O$ índice de circularidade é a relação existente entre a área da depressão e a área do círculo de mesmo perimetro, definida por Miller (1953, apud Cristofoletti 1980), pela equação:

(3) IC $=\mathrm{A} / \mathrm{AC}$

$$
\begin{aligned}
& \text { sendo: } \mathrm{IC}=\text { indice de círcularidade, } \\
& \mathrm{A}=\text { área da depressão, } \\
& \mathrm{AC} \text { (área do círculo de mesmo perímetro da depressão) }=\pi(\mathrm{P} / 2 \pi)^{2} \text {, } \\
& P=\text { perimetro da depressão. }
\end{aligned}
$$

A circularidade é um parâmetro sensivel a irregularidades no contorno das depressões. Os índices de circularidade mais altos refletem depressões com contornos mais suavizados, com área planimétrica geralmente menor $\mathrm{e}$, os indices mais baixos, ao contrário, refletem áreas maiores $\mathrm{e}$ contornos irregulares. Este parâmetro pode ser utilizado como critério indireto da separação entre depressões simples e compostas.

Em toda a área não foi encontrada uma variação significativa entre os valores médios do indice de circularidade (tabela 3.5). Todavia, existe uma considerável variação entre o valor máximo e mínimo que valem, respectivamente, 0,785 e 0,067. 
Através de mapas de distribuição de depressões fechadas produzidos pelo programa IDRISI, com base nos índices de circularidades, foram agrupados dois conjuntos de dolinas, um deles representando depressões com índice de 0 a 0,5 e um outro de 0,51 a 1,0 (fig. 3.10).

No mapa de depressões com índice de 0 a 0,5 (fig. 3.10a), existe o predomínio de formas exibindo contornos mais regulares e tendência a morfologia circular a subcircular, no caso associada principalmente com as depressões pequenas e simples. Já o mapa das depressões com indices inferiores a 0,5 (fig. 3.10b) demonstram o predomínio de formas elipticas e contornos irregulares, que proporcionalmente são maiores do que as depressões com índice superior a $0,5 \mathrm{e}$ por isso estão mais relacionadaos com dolinas compostas.

\begin{tabular}{|c|c|c|}
\hline SETYR & Tipo de depressão & Circularidade média (IC) \\
\hline NORTE & tolal & 0,56 \\
\hline SUL & perfil suave & 0,52 \\
\hline SUL & perfil cscarpado & 0,47 \\
\hline SUL & tolal & 0,51 \\
\hline ÁRL $\Lambda$ GILRA! & tolal & 0,53 \\
\hline
\end{tabular}

Tabela 3.5 - Indice de circularidade

\section{Densidade de sumidouros autogênicos}

Este índice indica a freqüência de pontos de absorção relacionados ao escoamento superficial coletados sobre a área carbonática de acordo com Williams (1972), Day (1976) e Karmann (1994). Segundo Karmann (op. cit.), quanto mais alto for o índice, maior será o grau de desmembramento da rede de drenagem superficial ou a continuidade dos canais fluviais. A densidade de sumidouros autogênicos é cerca de $60 \%$ maior no setor sul do que no setor a norte (tabela 3.6).

\begin{tabular}{|c|c|c|c|}
\hline SLTOR & $\begin{array}{c}\text { Núncros de pontos de } \\
\text { absorçđo }\end{array}$ & $\begin{array}{c}\text { Area total da supcrficic } \\
\text { carbonática }\left(\mathrm{km}^{2}\right)\end{array}$ & $\begin{array}{c}\text { Densidade de sumidouros } \\
\text { autogênicos }\left(\mathrm{D}_{\mathrm{sa}}\right)\end{array}$ \\
\hline NORTE & 385 & 276,41 & 1,39 \\
\hline SUL & 488 & 215,97 & 2,26 \\
\hline AREA GERAL & 873 & 492,38 & 1,77 \\
\hline
\end{tabular}

$\mathrm{D}_{\mathrm{S} \Lambda}=$ Números de pontos de absorção / Área total da superfícic carbonática

Tabela 3.6 - Densidade de sumidouros autogênicos 


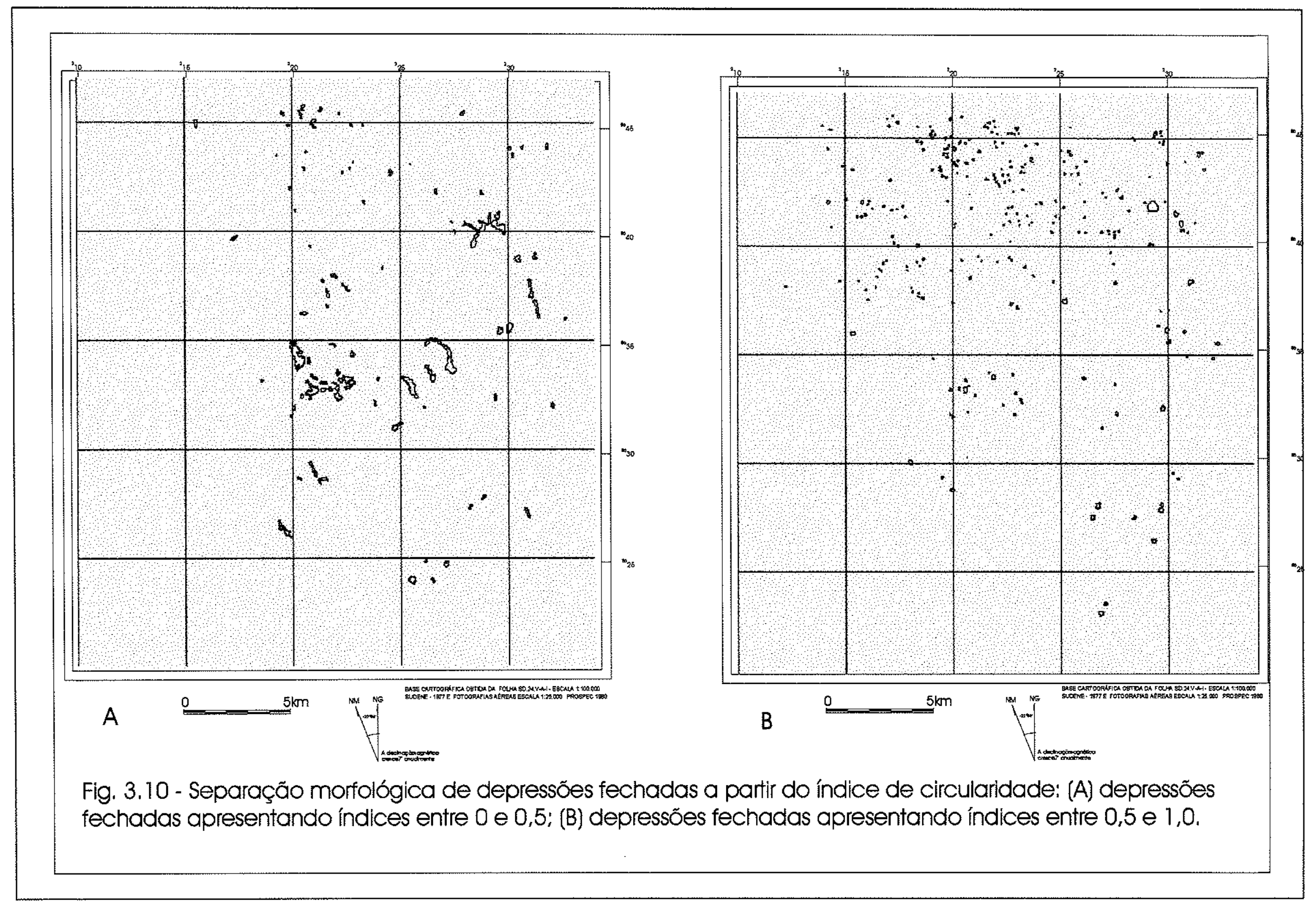




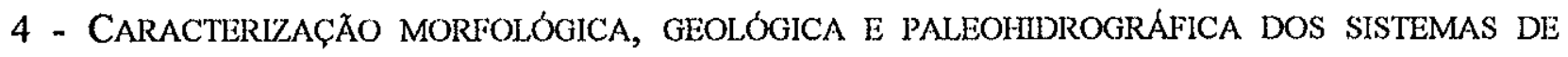
CAVERNAS LAPA DOCE E LAPA DA TORRINHA

\section{1 - Introdução}

O estudo morfológico de cavernas foi desenvolvido nos sistemas Lapa Doce e Lapa da Torrinha, que compreendem importantes sistemas na área de trabalho, os quais apresentam diferentes padrões morfológicos de condutos (fig. $4.1 \mathrm{e} \mathrm{fig.} \mathrm{4.2).}$

Em cada um dos sistemas foram mapeados trechos, com o objetivo de amostrar os diferentes padrões morfológicos em planta topográfica e seções transversais. Ao todo foram mapeados nove trechos de cavernas, sendo quatro deles localizados na Caverna Lapa Doce I, dois trechos na Lapa Doce 11 e três trechos na Lapa da Torrinha, totalizando cerca de $4.200 \mathrm{~m}$ de condutos mapeados (fig. 4.1 e fig. 4.2). A extensão mapeada corresponde ao comprimento da linha de trena projetado em planta.

Os mapas resultam de levantamentos topográficos a base de bússola, trena e clinômetro, nas escalas originais 1:250, 1:500 e 1:1000. A maior parte dos mapas utilizados possuem precisão estimada de $1^{\circ}$ para ângulos e de $10 \mathrm{~cm}$ para distâncias, consistindo de levantamentos nível 5 na classificação da Bristish Cave Research Association-BCRA (Martin et al. 1989). Os setores 7 e 9 não possuem avaliação quanto a sua precisão de mapeamento.

Estas plantas são utilizadas como base cartográfica, sendo imprescindiveis para o estudo geológico e das paleorrotas de fluxo hidrológico efetuados. Nelas, foram acrescentados os dados referentes ao mapeamento de estruturas geológicas, feições de dissolução do conduto, posicionamento e altura relativa de pilhas de sedimentos e setas com os sentidos dos paleofluxos de água. A partir destes mapas, são descritos os principais padrões morfológicos em planta, comparando-os aos modelos propostos por Palmer (1991), Ford \& Ewers (1978), White (1988), White \& Deike (1989) e Karmann (1994).

As seções transversais e perfis longitudinais, apresentadas conjuntamente com as plantas topográficas, servem como base para descrição da morfologia relativa às fases de iniciação e desenvolvimento de condutos em diferentes zonas hidrográficas. As sę̧ões e perfis também são úteis na representação da variação da altura entre o teto $\mathrm{e} o$ piso das galerias (constituído geralmente de sedimento) e descrição dos diferentes tipos de feições de dissolução identificadas. 


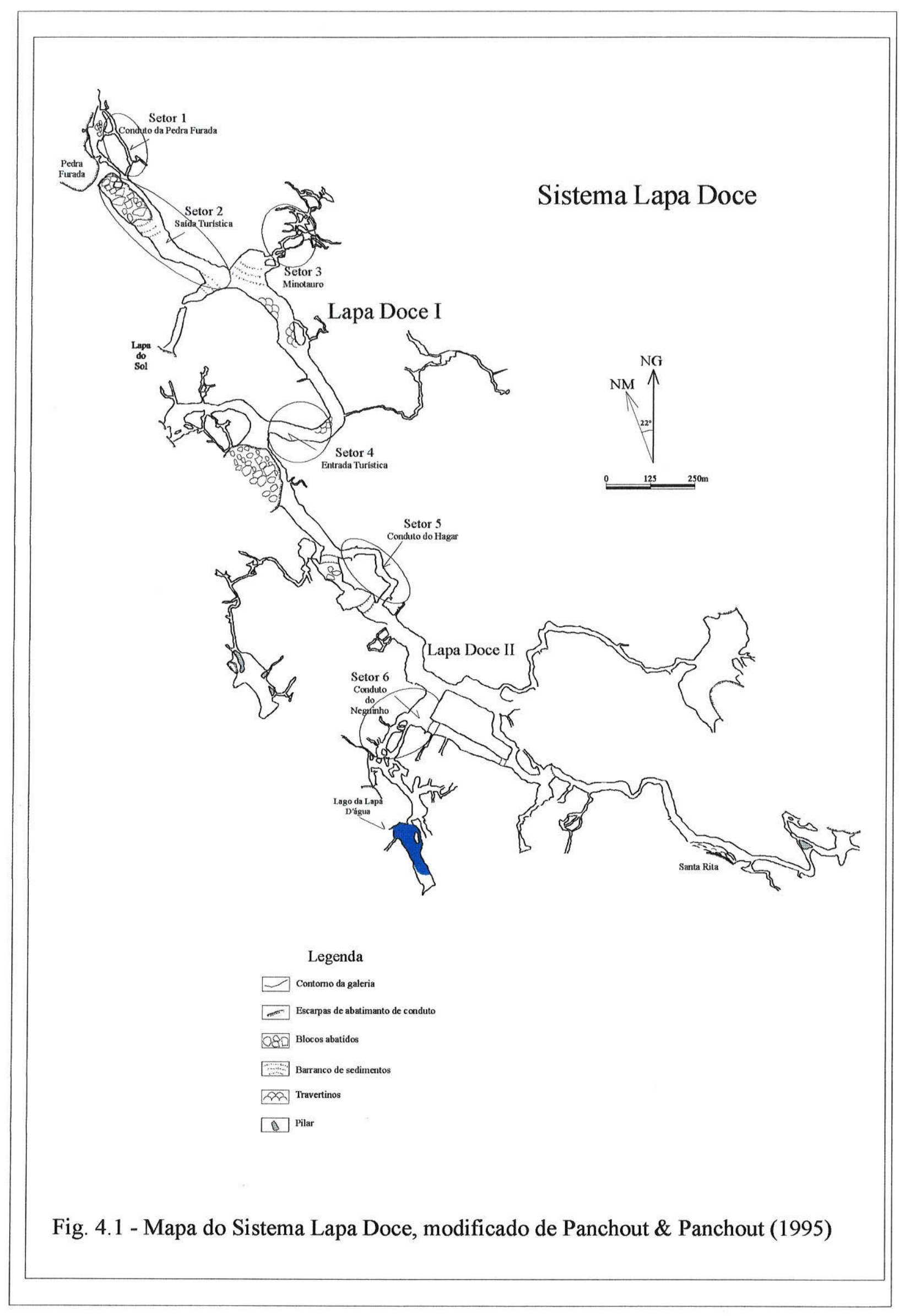




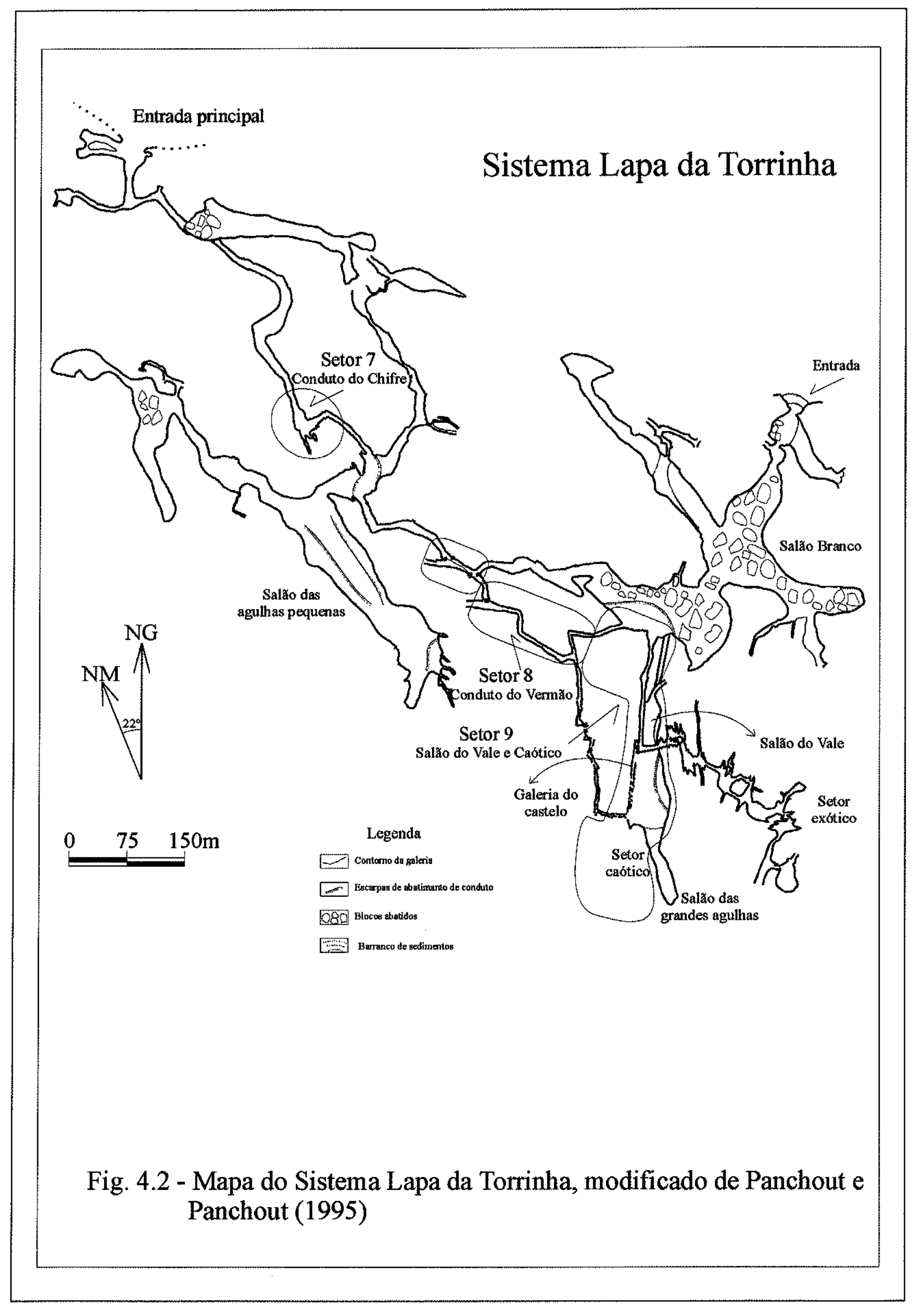


A hipótese de condicionamento da direção de condutos por estruturas geológicas pode ser confirmada, quando as orientações de passagens de cavernas possuirem uma distribuição similar à orientação de estruturas geológicas. Esta relação é verificada a principio através da comparação visual entre a orientação de estruturas geológicas mapeadas e dos segmentos de condutos nos mapas dos setores, com o auxílio de diagramas de rosetas e em seguida confirmada com o emprego de técnicas estatísticas.

A análise de orientação de passagens de cavernas é feita diretamente sobre os mapas confeccionados com a medição da direção e comprimento de segmentos retos que não apresentem desvios laterais superiores a $10^{\circ}$ e que sejam paralelos simetricamente às paredes dos condutos (Deike, 1989; Cheema \& Islan, 1995; Terlau \& Day, 1997). As passagens não interpretadas como lineares são descartadas do levantamento.

Os histogramas com intervalos de classe de $10^{\circ} \mathrm{Az}$ para direção e comprimento de segmentos de condutos e direção de fraturas são úteis para quantificar a similaridade da distribuição entre classes de dados.

A análise estatística de dados utiliza o teste Kolgomorov-Smimov para duas amostras com o objetivo de calcular o percentual de correlação entre as funções de distribuição de dois grupos de dados mutuamente independentes, de acordo com Conover (1980). O teste é não paramétrico e comprova se duas amostras foram extraídas da mesma população (ou de populações com mesma distribuição). $\mathrm{O}$ método é sensível a qualquer diferença nas distribuições das quais se extraíram as amostras, sendo indicado para o caso onde nenhuma suposição possa ser traçada a respeito da distribuição dos valores da população. Outra vantagem do teste é a de permitir a comparação de amostras com tamanhos desiguais. Nesta ocasião, pretende-se comparar a distribuição do número de observações em 18 intervalos de classe de $10^{\circ}$, correspondentes aos azimutes de grupos de fraturas e segmentos orientados de cavernas, admitindo-se $\alpha=0,05$. Este teste é utilizado também por Deike (1989), Cheema \& Islan (1995) e Terlau \& Day (1997).

\section{Fraturas e Falhas}

O mapeamento geoespeleológico contou com o levantamento de estruturas geológicas, como fraturas, falhas e planos de acamamento, nos setores escolhidos dos sistemas de cavernas estudados. Este levantamento constou principalmente do mapeamento dos traços de fraturas situados no teto das galerias. 
A medição das atitudes de planos foi dificultada por problemas de acesso ao teto das galerias. Nas paredes das galerias foram medidas as atitudes de planos de acamamento, fraturas de cisalhamento, fraturas preenchidas e falhas.

As fraturas constituem as estruturas tectônicas mais comuns e ocorrem em vátios tipos, tamanhos e espaçamentos. Os traços de fraturas são praticamente coincidentes com a direção da fratura correspondente, quando a superficie que o envolve é horizontal. Nos condutos mapeados os tetos são predominantemente subhorizontais, permitindo a aproximação entre a direção do traço com a direção do plano de fratura.

Foram classificadas fraturas preenchidas e de cisalhamento. A maior parte delas são preenchidas por calcita, podendo ser consideradas fraturas preenchidas quando não forem observados deslocamentos ao longo dos planos de fratura. Caso ocorram pequenos deslocamentos, a fratura passa a ser considerada como de cisalhamento.

\section{Planos de acamamento}

Os planos de acamamento compreendem superficies primárias que definem o limite dos estratos das rochas carbonáticas. Estes planos constituem as descontinuidades mais longas e contínuas encontradas.

Os estratos são geralmente tabulares e estão associados a rochas carbonáticas de granulometria fina. Estes estratos possuem espessura decimétrica a métrica, podendo ter estrutura interna maciça ou ser caracterizada por uma seqüência de finas laminações subparalelas. Localmente, são encontrados estratos sigmoidais associados a rochas mais grossas, contendo internamente estratificações cruzadas acanaladas. Rochas de composição silicosas, em geral camadas de sílex com espessura centimétrica a decimétrica e em alguns casos métrica, encontramse comumente intercaladas as rochas carbonáticas.

\section{Ocorrências de sedimentos clásticos nas cavernas da área}

Nas cavernas estudadas existe uma porção significativa de condutos que encontram-se parcialmente ou totalmente preenchidos por sedimentos. Em galerias com morfologia original ou sem abatimentos de blocos, os pisos das galerias são constituídos de sedimentos clásticos, sendo pouco comuns substratos rochosos. 
Muitas galerias, principais ou subsidiárias, têm sua terminação junto a pilhas de sedimentos posicionadas rente ao teto e outras conservam evidências de que o níveis de sedimentos, outrora mais altos, foram erodidos.

Estes sedimentos representam depósitos expressivos quanto á distribuição e espessura, chegando a preencher totalmente condutos com mais de $10 \mathrm{~m}$ de altura. Sua caracterização sedimentar é tema de estudo de Fernando V. Laureano, (dissertação de mestrado em andamento). A ocorrência destes sedimentos foi mapeada no setores de cavernas cartografados, tendo em vista verificar a sua influência nos processos de aberturas e modificação da morfologia de condutos.

\section{Paleorrotas de fluxo de água}

As paleorrotas de fluxo de água foram delineadas através de levantamentos de marcas de corrente (scallops), que são feições de dissolução rasas e com formato conchoidal, situadas principalmente nas paredes das cavernas (Bretz, 1942). O levantamento consta da medição dos sentidos de paleocorrentes e o comprimento das marcas de correntes assimétricas, preferencialmente junto às seções transversais (fig. 4.3). Os sentidos das paleocorrentes estão orientados para a parte mais rasa da concavidade que caracteriza as marcas de correntes, situada entre suas cristas (fig. 4.4). O Comprimento das marcas de correntes medido perpendicularmente às cristas, indica velocidade e tipo de fluxo durante a formação da galerias (Curl, 1974; Goodchild \& Ford, 1971). Pequenas marcas de corrente indicam fluxo com mais alta velocidade e mais turbulentos, comuns em galerias mais estreitas e com fina lâmina d’água, enquanto as grandes marcas de corrente indicam fluxos mais lentos, com tendência a ser mais laminar, típicos de condutos mais largos e com preenchimento total de água.

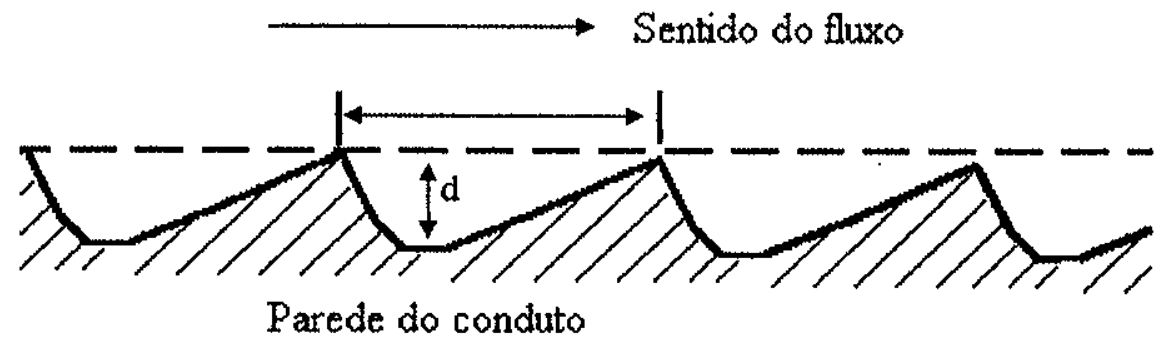

Fig. 4.3 - Esquema para orientação do sentido de fluxo através de marcas de correntes. Modificado de Curl (1974). 


\subsection{1 - Setores mapeados no Sistema Lapa Doce}

O Sistema Lapa Doce está situado na porção central da área, entre a extremidade do Vale do Riacho Água de Rega e o Vilarejo da Santa Rita, passando por baixo da rodovia BR-330. O seu prolongamento entre estes dois pontos é estimado em aproximadamente $3 \mathrm{~km}$ (fig. 2.3).

O padrão da caverna é de um sistema distributário, caracterizado por amplas galerias com direção geral NW-SE e por diversos ramos subdidiários dispostos transversalmente ao prolongamento maior da galeria principal (fig. 4.1). O acesso a ela pode ser feito através de várias dolinas com perfil escarpado, encontradas ao longo de sua extensão mapeada.

Ferrari (1990) definiu quatro niveis de condutos para o Sistema Lapa Doce. Dois niveis estão situados respectivamente a 10 e $16 \mathrm{~m}$ acima do piso das galerias principais. Um outro nível está situado a $4 \mathrm{~m}$ abaixo da galeria principal.

Dentre os trechos mapeados (fig.4.1), os setores correspondentes ao conduto da Pedra Furada (setor 1), Conduto do Hagar (setor 5) e Conduto do Neguinho (setor 6) constituem niveis topográficos posicionados junto a base ou um pouco abaixo das galerias principais do sistema. $\mathrm{O}$ Setor Minotauro (setor 3) compreende um ramo distributário situado acima da base da galeria principal e, os setores 2 e 4 corresponden a trechos da galeria principal do sistema.

\section{Conduto da Pedra Furada}

Este setor encontra-se localizado no extremo norte da Caverna Lapa Doce I, próximo a dolina de colapso que caracteriza a entrada da caverna pelo vale do Riacho Água de Rega (Anexo 2). Foram mapeados cerca de $420 \mathrm{~m}$ de condutos neste setor.

\section{Morfologia}

O setor é caracterizado morfologicamente por ramos de condutos em alça ou bypass (Ford \& Willians, 1989), que iniciam-se na galeria principal próximo a entrada norte do sistema em condutos menores com direções N-S e E-W. Estes condutos juntam-se a um segmento maior que prossegue por mais de $90 \mathrm{~m}$ para sul, até bifurcar-se. Um dos ramos desta bifurcação é um conduto orientado para $\mathrm{E}$, que segue para um lago intermitente que sifona a galeria. $\mathrm{O}$ outro ramo liga-se à galeria principal à $\mathrm{N}$, onde ocorre a dolina de abatimento. 
Os condutos possuem morfologia irregular em seção transversal, caracterizada por uma acentuada variação de suas dimensões verificadas ao longo do setor (Anexo 2). A maior parte das seções possuem forma aproximadamente triangular, caracterizada por teto estreito e paredes que tendem a ficar mais largas rente ao piso, a exemplo das seções I-I', S-S' e T-T', a norte do setor e B-B', C-C', D-D' ao centro e sul do setor. Nessas seções, a largura varia entre 2 e $4 \mathrm{~m}$ nas porções intermediárias a basais, com exceção das seções S-S', P-P', I-I e D-D', que possuem largura superior a $4 \mathrm{~m}$ na base. Estas seções ocorrem sempre associadas a presença de fraturas e cúpulas de corrosão no teto das galerias (fig. 4.5). Sua largura no topo varia entre 0,6 a 1,6m.

As demais seções possuem teto relativamente mais largo, mantendo aproximadamente as mesmas proporções, nas porções intermediárias a basais, a exemplo das seções $R-R$ ' e W-W'. A morfologia retangular no caso das seção W-W', está relacionada ao revestimento do teto do condutos locais por camadas de sílex.

A altura nas seções varia entre 6 e 7,5m, na maioria das seções, alcançando valores maiores nas seções E-E' ao centro do setor e X-X' ao sul do setor, respectivamente, de 9 e $11 \mathrm{~m}$. Outras seções possuem alturas geralmente inferiores a $3,5 \mathrm{~m}$, quando situadas em condutos com teto revestido por camadas de silex, como acontece nos condutos a sul do setor ou alto nivel de preenchimento sedimentar, comum nos condutos a norte do setor.

Em perfil topográfico observa-se que a linha que define o teto não é contínua ao longo dos condutos e que alguns trechos de condutos possuem tetos com alturas sensivelmente diferentes (Anexo 2, perfil $\lambda-\lambda^{c}$ ). A altura do perfil $\lambda-\lambda^{c}$ acompanha a variação morfológica dos condutos e o preenchimento sedimentar no seu piso. A porção central do setor é caracterizada por um conduto alto que, em alguns trechos pode alcançar $11 \mathrm{~m}$, onde se ressaltam seções triangulares com cúpulas de corrosão e fraturas no teto. O trecho, onde ocorrem seções retangulares na porção centro-sul do setor, apresenta níveis de sílex no teto com mais de $50 \mathrm{~cm}$ de espessura.

Observa-se também no perfil $\lambda-\lambda$ que o ramo de conduto que se liga a sul com a dolina de abatimento não segue as mesmas características do restante do setor. Ele é mais baixo e seu teto e piso estão inclinados positivamente, entre 4 a $8^{\circ}$ no teto e 8 a $13^{\circ}$ no piso, o que caracteriza uma passagem em perfil ascendente, com desnível de $8 \mathrm{~m}$. O perfil na sua porção norte evidencia um ramo de conduto onde se tem preservado o piso de sedimento, marcado também em planta, por uma escarpa de sedimento com desnível de $3,2 \mathrm{~m}$. Em outras partes do setor o piso é rochoso ou, então, é revestimento por uma delgada camada de sedimento. 


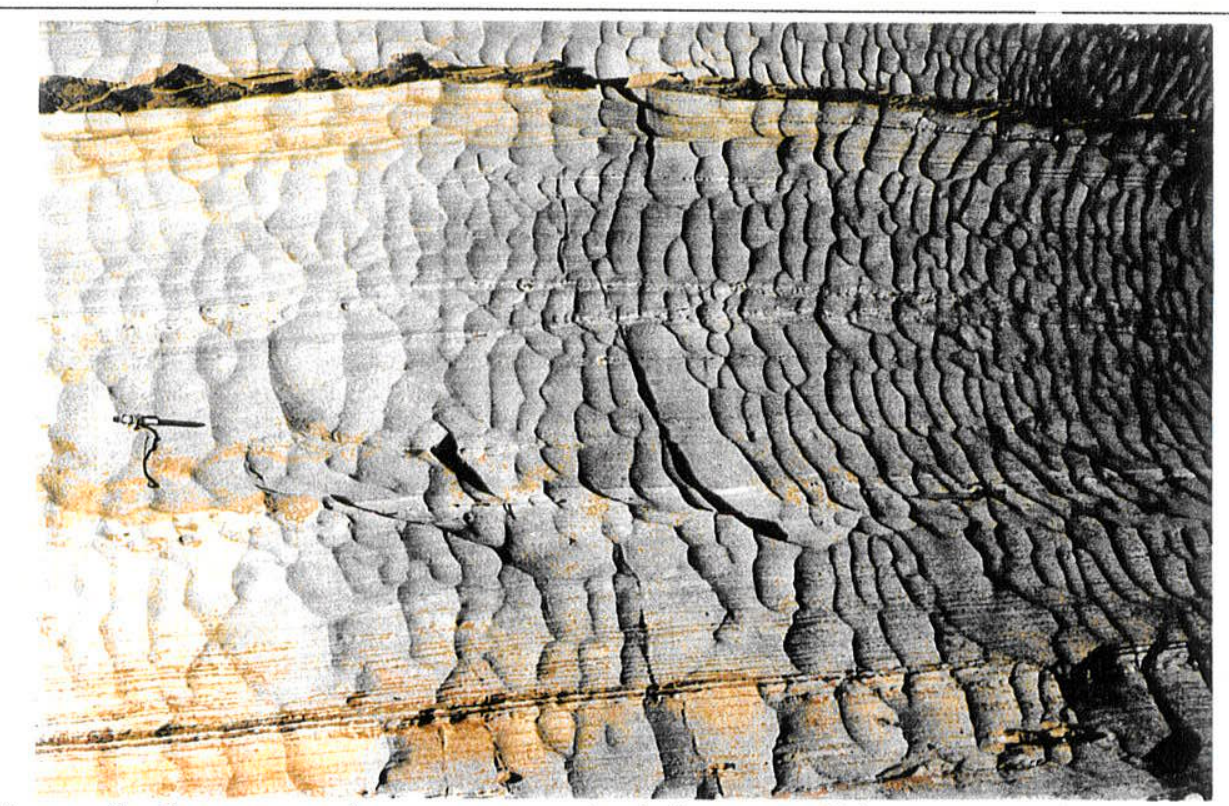

Fig. 4.4 - Exemplo de marcas de corrente assimétricas, medidas em paredes de condutos, setor 1 (Conduto da Pedra Furada).

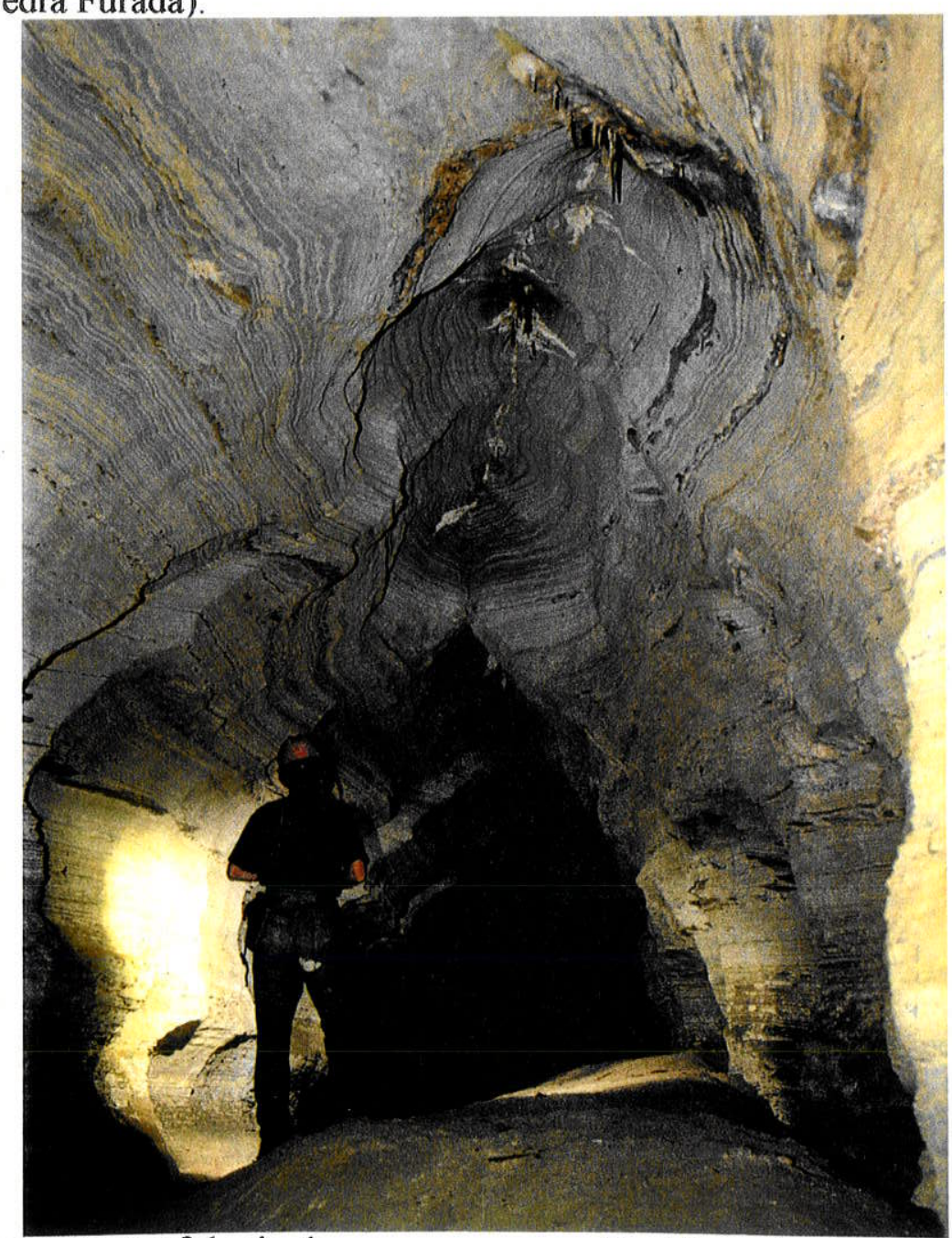

Fig. 4.5 - Condutos com morfologia de canyoris com seções triangulares apresentando cúpulas de corrossão alinhadas concordantemente na direção de fraturas no teto, situado na porção norte do setor 1 (Conduto da Pedra Furada). 


\section{Condicionamento estrutural da morfologia}

Os segmentos de condutos, de acordo com o histograma de direção(Anexo 2A), estão preferencialmente orientados segundo os intervalos $\mathrm{N}$ a N10E e N10-20W e secundariamente N50-60W. O histograma de comprimento, em comparação, apresenta orientação preferencial para $\mathrm{N}$ a N10E (Anexo 2B).

Os planos de acamamento medidos possuem atitude entre N20-40W e mergulham 5 a $20^{\circ}$ para NE. As fraturas estão presentes no teto da maior parte das galerias e situam-se preferencialmente ao centro delas. As cúpulas de corrosão desenvolvem-se concordantemente com a direção das fraturas, assim como, a direção de vários trechos de paredes observados em planta (fig. 4.5). Estas fraturas ocorrem em diversos tamanhos, muitas vezes, em segmentos com mais de $10 \mathrm{~m}$ de comprimento, constituídos em sua maioria, de fraturas decimétricas a métricas com padrão escalonado ou en echelon (Hancock, 1985). Ocorrem também pequenas galerias com morfologia de fenda, que representam tentativas de aberturas de condutos sob fraturas, a exemplo do corte $U-U^{\prime}$, ao norte do setor. Outro tipo de estrutura comum no setor são as fraturas de cisalhamento com direção predominante NW-SE, identificadas e medidas nas paredes.

As principais orientações dos traços de fraturas, de acordo com o histograma de direção, são N10-20W, seguida pelos intervalos N20-30W e N40-50W, sendo a distribuição das fraturas relativamente parecida com a apresentada pelos histogramas de direção de segmentos de condutos (Anexo 2C). O teste de correlação estatístico K-S confirma que existe correlação na distribuição entre as direções dos traços de fraturas e segmentos de passagens de cavernas.

\section{Paleorrotas de fluxo}

As marcas de corrente indicam que os sentidos de paleofluxo possuem orientação de norte para sul. Isto sugere que a galeria foi formada através de rotas de fluxos provenientes da entrada da caverna, que estavam direcionadas a princípio para o lago situado na parte sul do setor.

O fluxo de água acessou a dolina de abatimento no extremo sul do setor através de uma passagem em perfil ascendente a sul do setor (perfil $\lambda-\lambda^{\prime}$ ), que inicia-se próximo ao lago. A morfologia sugere que este conduto foi ampliado em condições de alta pressão hidrostática, favorecida por uma grande concentração local de fraturas.

\section{Conduto principal da Caverna Lapa Doce 1: saída do trecho turístico}

Este setor encontra-se localizado junto à dolina de abatimento que corresponde à saída do trajeto turístico realizado na galeria principal da caverna (Anexo 3). 


\section{Morfologia}

A galeria possui cerca de $420 \mathrm{~m}$ de comprimento mapeados, sendo que $200 \mathrm{~m}$ desse total, encontram-se situados ao redor da dolina de abatimento e o restante compreende trechos com morfologia original ainda bem preservada.

O padrão morfológico deste setor é caracterizado pela presença de uma galeria principal com amplas dimensões, que está conectada lateralmente com vários ramos de condutos menores. Os ramos Minotauro e Pedra Furada ligam-se à galeria principal pelo lado leste e os ramos Lapa do Sol e Doce, pelo lado oeste. Estes ramos laterais estão posicionados abaixo do teto da galeria em alturas intermediárias e próximas ao seu piso.

O conduto principal possui direção geral N-S neste setor. A sua largura varia entre 30 a $60 \mathrm{~m}$, sendo mais largo a norte. Os pontos mais altos da galeria observados nas seções A-A', B-B' e C-C', possuem 17 a 18,5m de altura. Em seção transversal, observou-se um canal no topo do conduto, demarcado em planta através da projeção do traço de suas paredes. As seções referidas apresentam morfologia elipsoidal e também um canal no teto com largura entre 14 e $15 \mathrm{~m}$ e altura entre 2 e $4 \mathrm{~m}$, caracterizado por topo plano.

$\mathrm{Na}$ área ao lado da dolina, ocorre uma grande pilha de blocos abatidos do teto e paredes da galeria, juntamente com o solo proveniente da superficie. As seções D-D', E-E', F-F' e G-G', demonstram que o estreito trecho preservado ao lado da pilha de blocos, foi formado por entalhamento lateral dos cursos de água que passaram a contornar a área envolvida pelos blocos. O piso deste trecho é rochoso, diferentemente de outras partes do conduto principal. Nele são encontrados atualmente pequenos lagos intermitentes, alimentados por água proveniente de fraturas nas paredes.

\section{Condicionamento estrutural da morfologia}

O conduto principal neste setor não coincide com importantes alinhamentos de fraturas, as quais possuem pequenas dimensões e são pouco numerosas.

Os planos de acamamento com mergulhos suaves possuem direções transversais à direção da galeria. Portanto, não há, condicionamento estrutural evidente neste trecho da caverna.

\section{Paleorrotas de fluxo e preenchimento sedimentar}

A rota de paleofluxo possui orientação NW para SE e segue a direção geral do gradiente hidráulico do Sistema Lapa Doce. Os ramos laterais são do tipo distributário em relação à galeria principal, pois as paleocorrentes estão orientadas da galeria para os ramos (Anexo 3). 
As escarpas de sedimentos preservadas, principalmente na entrada dos ramos Lapa do Sol e Minotauro, situadas em lados opostos da galeria possuem topos com alturas aproximadamente semelhantes em relação à base da galeria. Estas escarpas são testemunhas da erosão de um antigo nível piso da galeria, posteriormente entalhado.

\section{Setor Minotauro}

O setor localiza-se a NE da Galeria principal da Caverna Lapa Doce I, cerca de $280 \mathrm{~m}$ da dolina de abatimento, na porção norte da caverna. Neste trabalho foram mapeadas de $739 \mathrm{~m}$ de galerias no setor.

\section{Morfologia}

A morfologia em planta está caracterizada por condutos com largura uniforme, sinuosos e curvilíneos com padrão geral em rede e localmente com trechos entrelaçados (Anexo 4). Na parte oeste do setor, os condutos estão ligados a um amplo salão de abatimento com altas pilhas de sedimento na base dos blocos. Estes condutos dão acesso, a leste, a um outro salão com várias entradas de galerias, que se prolongam para NE.

Em seção transversal, os condutos superiores apresentam morfologia elipsoidal caracterizada por tetos planos (fig. 4.6). Estes condutos mudam na base geralmente para canyons com paredes irregulares, a exemplo das seções $f-f^{\prime}, h_{-} h^{\prime}, i-i^{\prime}, j-j j^{\prime}$ e g-g'. Em um nível inferior de galerias as seções transversais predominantes são em canyon (fig. 4.7).

$O$ teto entre as galerias do setor não apresentam variações acentuadas de altura, de acordo com os perfis longitudinais $1,2,3$ e 4 . No entanto, o piso constituído de sedimento, encontra-se erodido ao longo do setor nos locais indicados pelas escarpas na planta (Anexo 4). As escarpas definem os limites das superficies planas que marcam o piso em determinados condutos com os vales formados pela erosão do piso. Nos vales ocorrem pequenos lagos e rios intermitentes, que originam pequenos condutos em níveis inferiores.

Observa-se, também, nos perfis trechos de galerias com piso plano e trechos em que ele foi erodido. A altura das seções de galerias, onde o piso é plano, varia entre 0,5 a $3,0 \mathrm{~m}$ e em outros locais é de 5 a $9 \mathrm{~m}$, o que caracteriza desníveis, ocasionados de erosão do sedimento superior a $5 \mathrm{~m}$, em alguns pontos do setor. Nas seções r-r' e s-s' são encontrados niveis de sedimentos residuais que indicam a erosão do preenchimento sedimentar.

Níveis de pendants no teto (fig. 4.8), estão associados a pequenos salões na porção leste do setor, onde ocorrem resquícios de sedimentos, juntamente com pequenos canais (seção p-p'). 


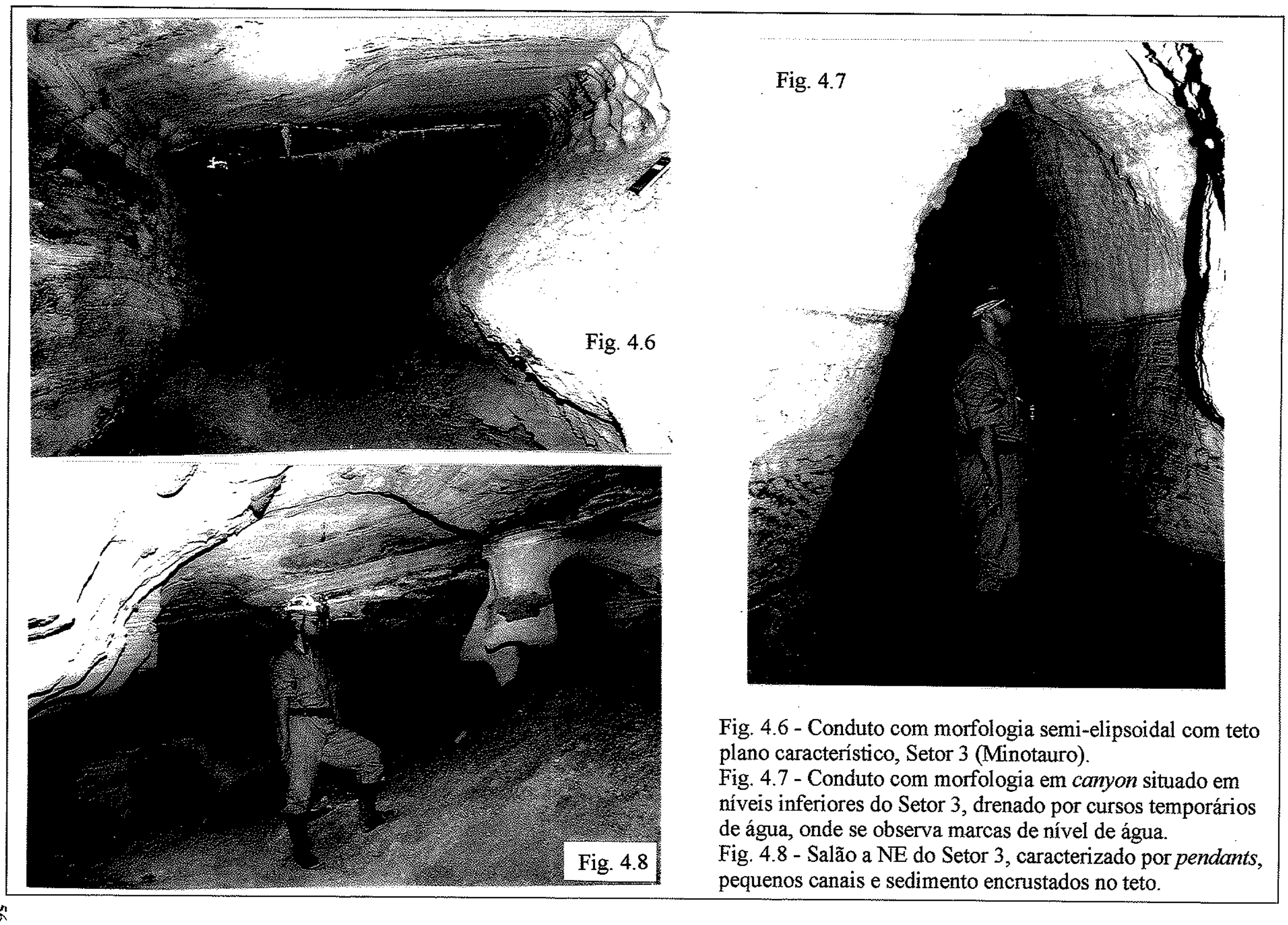




\section{Condicionamento estrutural da morfologia}

A maior freqüência de orientação de condutos está nos intervalos N70-80E e secundariamente N10-20W e N80-90E, de acordo com o histograma de direções (Anexo 4A). Já os intervalos com maior freqüência no histograma de comprimento estão orientados para N8090E e N10-20W (Anexo 4B).

Os traços de fraturas ocorrem em pequeno número e estão irregularmente distribuídas ao longo dos condutos. Elas medem entre 2 a $15 \mathrm{~m}$ e são preferencialmente orientadas nos intervalos N20-30E e secundariamente nos intervalos N40-50E e N60-70W (Anexo 4C). A comparação entre os histogramas sugere não haver correlação entre a distribuição de fraturas e segmentos de condutos. O resultado indicado pelo teste $\mathrm{K}-\mathrm{S}$ não tem efeito prático neste caso, pois o número de fraturas observados é muito pequeno e mal distribuido ao longo do setor.

\section{Paleorrotas de fluxo de água e preenchimento sedimentar}

$\mathrm{O}$ setor possui duas rotas de fluxos bem definidas. Uma das rotas é mais antiga e proveniente do conduto principal, sendo orientada para E-NE. Esta rota envolve a maior parte dos condutos do setor, sendo caracterizada por marcas de corrente com médias de comprimento em seções elípticas variando entre 20 e $32 \mathrm{~cm}$. A outra rota é associada a pequenos córregos intermitentes e está orientada para WSW ou para área da galeria principal, estando relacionada com pequenos condutos apresentando seções de camyons, situados em níveis inferiores (fig. 4.7). $\mathrm{O}$ conduto inferior, temporariamente drenado por água oriunda da superficie via fraturas, que forma um córrego iniciado sobre escorrimentos de calcita, geralmente impregnados de solo argiloso da superficie. As marcas de correntes neste conduto variam entre 3,2 e $16 \mathrm{~cm}$ de comprimento.

\section{Conduto principal da Caverna Lapa Doce I: entrada do trecho turístico}

O setor mapeado encontra-se localizado na galeria principal da Lapa Doce 1 , junto à dolina que subdivide Sistema Lapa Doce nas caverna Lapa Doce I e II. Este trecho corresponde ao início do trajeto turístico da caverna e possui cerca de $280 \mathrm{~m}$ de condutos mapeadas (Anexo 5 ).

\section{Morfologia}

$O$ percurso mapeado possui $220 \mathrm{~m}$ de comprimento e largura que varia entre 35 a $50 \mathrm{~m}$. Orientando-se da direita para a esquerda do mapa, esta galeria inflexiona-se fortemente de N30E para N40W. A altura máxima, de acordo com as seções transversais, varia entre 10 a $20 \mathrm{~m}$. 
O conduto cncontra-se parcialmente modificado por processos de incasão, como constatado pelo acúmulo de pilhas de blocos em alguns locais da galeria. No entanto, ocorre um canal, que encontra-se situado no teto junto a parede do lado W (Anexo 5). Esta feição possui forma em seção de meia elipse, com largura de 25 a $30 \mathrm{~m}$ em planta e altura entre 2 e $3 \mathrm{~m}$, de acordo com os cortes A-A' e E-E' (fig. 4.9).

A galeria é mais larga no lado da parede SSE, o que caracteriza uma morfologia típica do processo de entalhamento lateral desenvolvido em zona vadosa (fig. 4.9). No mesmo lado da galeria ocorre um pequeno córrego formado por acumulação de água proveniente de fraturas e eventuais cheias, que entalha lateralmente a parede SE e erode o piso de sedimento. $O$ desnivel atual na superficie do piso é de 2,5 a $7 \mathrm{~m}$, sendo evidentemente mais baixo no lado $\mathrm{SE}$ da galeria. As paredes nas seções A-A', B-B'e C-C', são mais inclinadas de um lado do que de outro, sugerindo que o entalhamento lateral foi importante também nas porções mais superiores do conduto. Patamares ou nolches (Slabe, 1995), encontram-se nas paredes e indicam paleo-níveis de água que entalharam as paredes.

\section{Condicionamento estrutural da morfologia}

$O$ acamamento, possui orientação média NW-SE com mergulho entre 4 a $18^{\circ}$ para NE. Os traços de fraturas mapeados constituem pequenos alinhamentos em proporção ao tamanho da galeria e medem entre 1 e $15 \mathrm{~m}$. Os principais intervalos de orientação dos traços de fraturas são para N60-80E e secundariamente para N50-60E, não concordando, portanto, com a direção dos segmentos da galeria (Anexo 5A). A inflexão do segmento de conduto não se relaciona, portanto, com as fraturas observadas no conduto.

\section{Paleorrotas de fluxo e preenchimento sedimentar}

A orientação de paleofluxo medido através de marcas de corrente é de SE para NW, contradizendo-se ao sentido geral do fluxo, que é de NW para SE. Um importante ramo distributário com direção NE-SW encontra-se ligado no extremo noroeste da galeria principal, junto à dolina de abatimento.

As marcas de corrente apresentam diferentes comprimentos médios entre a base e o topo da galeria. Em niveis próximos ao teto são observados marcas de corrente com comprimento estimado em mais de $40 \mathrm{~cm}$, a exemplo da zona 3 do corte E-E'. Em níveis intermediários e sobre as pilhas de sedimento, ocorrem marcas de corrente com comprimento médio de $24,3 \mathrm{~cm}$, na zona 4 do corte E-E'. Por fim, em niveis intermediários a basais situados até $5 \mathrm{~m}$ acima do piso, 
ocorrem marcas de corrente com comprimento médios respectivamente de 13,4 e $8,1 \mathrm{~cm}$, nas zonas 1 e 2 do corte E-E' e 6,2cm próximo base das seções B-B' e C-C' no lado SW da galeria.

As marcas de corrente com menor comprimento estão situadas, portanto, em trechos entalhados lateralmente na base da galeria, enquanto as marcas de corrente com maior comprimento ocorrem próximas ao teto e sobre as pilhas de sedimentos.

\section{Setor do Conduto do Hagar}

O Setor do Conduto do Hagar encontra-se localizado na Caverna Lapa Doce II, a cerca de $300 \mathrm{~m}$ a SE da entrada principal (fig. 4.1). Este setor consiste de $522 \mathrm{~m}$ de condutos mapeados.

\section{Morfologia}

Este conduto possui morfologia em planta do tipo alça ou bypass (Ford \& Ewers, 1978) e compreende um desvio do conduto principal. $O$ início e término deste conduto ocorre junto ao empilhamentos de sedimentos, sotopostos a blocos abatidos, onde ocorrem escarpas estimadas em mais de $15 \mathrm{~m}$ de altura (Anexo 6).

Em planta, o conduto principal apresenta traçado sinuoso, com trechos com direções E-W e NW-SE. $O$ conduto bifurcar-se próximo a sua extremidade, onde um ramo prolonga-se para $\mathrm{E}$ até ficar parcialmente preenchido por sedimento, e o outro segue em direção a galeria principal.

$\mathrm{O}$ conduto principal inicia-se a NW com piso rochoso suavemente inclinado para $\mathrm{E}$, até alcançar um patamar com cerca de $2 \mathrm{~m}$ de altura (fig. 4.10). Este patamar encontra-se entalhado por vários canyons, com direção E-W e NE-SW e profundidade variando entre 2 a $5 \mathrm{~m}$. Na base dos canyons, e em continuidade com o piso do inicio do conduto existe um pequeno salão drenado por um lago temporário, que constitui um nível inferior do conduto.

Em seguida, o mesmo patamar é entalhado por um único canyon na base da galeria com largura entre 5 e $6 \mathrm{~m}$. Esta canyon possui traçado sinuoso e tende a erodir o patamar de um lado do conduto e preservá-lo do lado oposto (Anexo 6). Esta variação do entalhamento lateral é associada à característica meandrante da drenagem subterrânea que erodiu o piso rochoso, tanto em planta como em seção transversal.

A seção transversal $A-A^{\prime}$ corresponde ao início do conduto principal, que neste trecho possui cerca de $5,5 \mathrm{~m}$ de altura e $12 \mathrm{~m}$ de largura. As seções B-B'a F-F' ilustram o relevo na área do patamar, caracterizado pela incisão de canyons em diversas profundidades. As seções G-G' a $\mathrm{V}-\mathrm{V}$ ' destacam o relevo das paredes do canyon no piso do conduto principal, onde patamares rochosos possuem alturas entre $3 \mathrm{e} 4 \mathrm{~m}$. A base do canyon é revestida por sedimentos clásticos. 


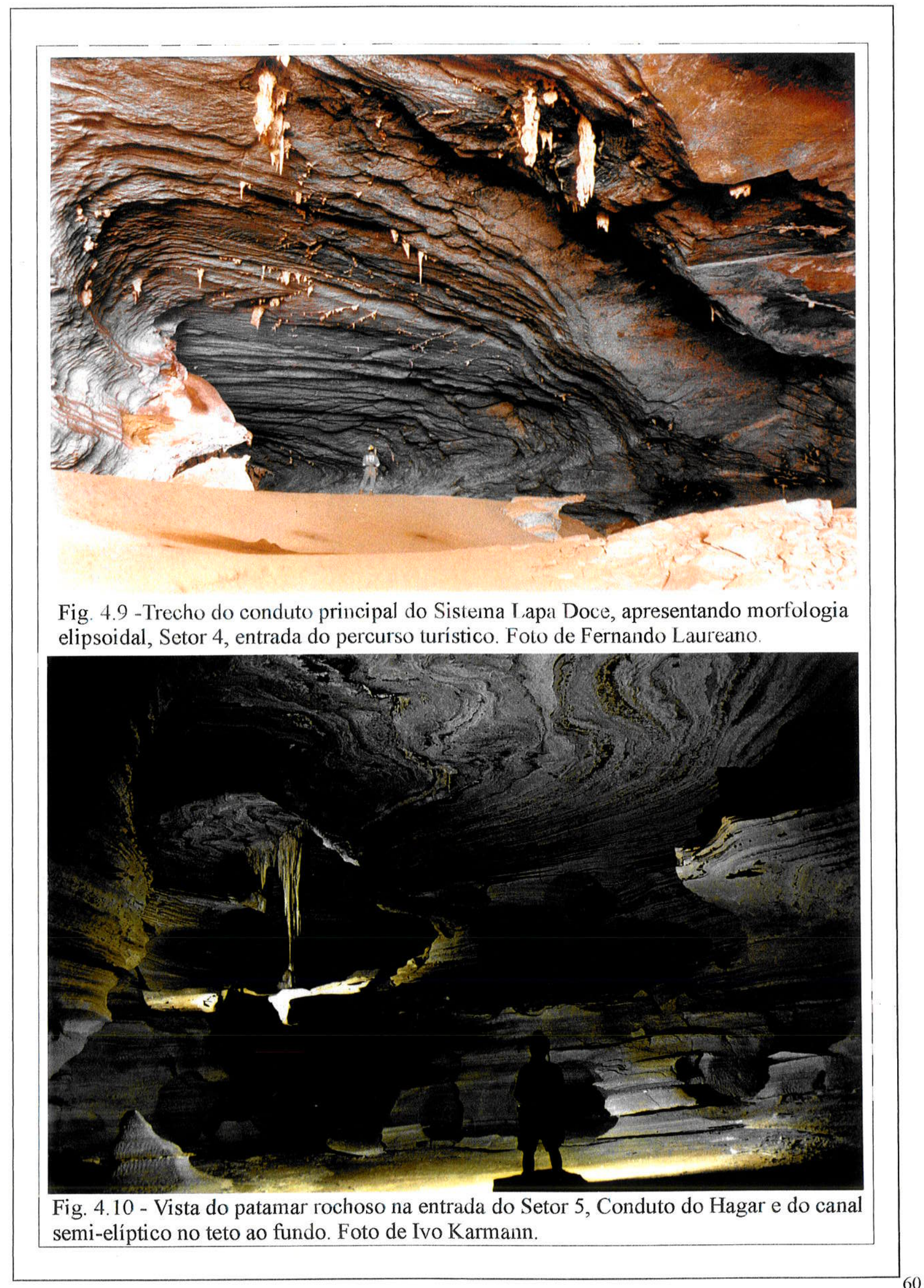


No topo do conduto principal é observado um canal com forma semi-elíptica a exemplo nas seções I-I' e R-R' (fig. 4.10). A dimensão desta feição varia nas seções transversais entre 1,5 e $3 \mathrm{~m}$ de altura e 5 e $6 \mathrm{~m}$.

\section{Condicionamento estrutural da morfologia}

$O$ conduto apresenta segmentos com orientação dispersa, mas com uma discreta preferência dos intervalos N80-90W, N50-70W e N20-30E, de acordo com o histograma de direção de segmentos de condutos (Anexo 6A). O histograma referente ao comprimento de segmentos indica intervalos preferenciais a N80-90W e N50-60W, mas com muita dispersão (Anexo 6B). Este comportamento na orientação dos segmentos de condutos é reflexo do padrão curvilíneo predominante nesta galeria do setor.

As fraturas estão presentes principalmente no inicio do conduto, porção NW do setor, onde se observa segmentos com até $40 \mathrm{~m}$ de comprimento, estando praticamente ausentes no restante do setor. Neste trecho, elas estão dispostas no piso e no teto da galeria principal ou de pequenos condutos laterais com morfologia em canyon. A maior parte delas são transversais ao conduto principal, estando orientadas preferencialmente nos intervalos N0-20W e N20-30E (Anexo 6C).

A quase ausência de fraturas e a disposição transversal dos planos de acamamento em relação a direção das galerias ao longo do setor, justifica o não condicionamento das passagens por estruturas tectônicas, salvo alguns entalhamentos com orientação N20-30E, situados na porção NW do setor.

\section{Paleorrotas de fluxo e preenchimento sedimentar}

Os sentidos de paleofluxo medidos a cada seção transversal, em diferentes alturas, indicam que a principal rota de fluxo estava direcionada de NW para SE. Esta rota iniciava-se na galeria principal da caverna, bifurcando-se a SE, na saída do setor. Nesta bifurcação, o ramo direito dá acesso à galeria principal, enquanto o ramo esquerdo está parcialmente obstruído por sedimentos. Estes sedimentos, ainda preservados no ramo esquerdo, foram quase que totalmente erodidos no restante do setor.

A presença de marcas de corrente, muito pequenas, com comprimentos inferiores a $3 \mathrm{~cm}$, sugere que o fluxo que erodiu o piso rochoso do setor é caracteristicamente vadoso. 
Em condutos atualmente preenchidos por sedimentos são observados pequenas marcas de corrente sobre outras maiores que $30 \mathrm{~cm}$ de comprimento, indicando uma provável mudança nas características do fluxo durante a evolução dos condutos.

\section{Setor do Conduto do Neguinho}

O setor encontra-se localizado próximo a bifurcação entre os condutos principais da Caverna Lapa Doce II, no ramo que prossegue em direção à saída da Lapa D'Água e lago homônimo (Anexo 7). A extensão de condutos mapeados neste setor é de $610 \mathrm{~m}$.

\section{Morfologia}

O setor é constituído por dois níveis de condutos. O nível superior inclui as entradas de condutos principais da caverna, como o ramo da Santa Rita e o ramo da Lapa D’Água. O nível inferior está situado entre 4 e $6 \mathrm{~m}$ abaixo do superior (Anexo 7).

O ramo principal da caverna na entrada do setor à NW, possui a proximadamente $20 \mathrm{~m}$ de largura e entre 8 a $10 \mathrm{~m}$ de altura. A entrada do ramo da Santa Rita possui a mesma largura, no entanto sua altura é de apenas $3 \mathrm{~m}$. O teto de ambas galerias estão em continuidadem existindo um pronunciado desnivel de aproximadamente $10 \mathrm{~m}$ entre os pisos constituído de sedimentos, como mostra a seção 00-3 (Anexo 7). Ocorre ainda uma grande quantidade de blocos abatidos no local.

$O$ desnivel entre os pisos é ocasionado pela erosão do sedimento que ocorre preferencialmente na direção do ramo da Lapa D'Água. As escarpas de sedimentos apresentadas na planta (Anexo 7) estão dispostas junto as paredes e entradas de condutos. Elas indicam locais onde ficou preservada a superficie do antigo piso sobre os sedimentos que envolvia as galerias maiores. A inclinação destas escarpas é de $25^{\circ}$ no corte B-B' e $40^{\circ}$ no corte C-C'.

O ramo da Lapa D'Água é caracterizado pela presença de dois canyons subparalelos orientados para N40E e N65E (Anexo 7). Estes canyons são cortados por pequenos condutos com padrão entrelaçado. $\mathrm{O}$ piso destes canyons é rochoso e possui profundidade que não ultrapassa $2,5 \mathrm{~m}$. Este piso constitui o teto das galerias principais do nível inferior e termina abruptamente, com desniveis de 6 e $4 \mathrm{~m}$, de acordo, respectivamente com os cortes C-C' e E-E'. A altura das seções neste trecho do setor varia de 12 a $20 \mathrm{~m}$. As seções A-A', B-B' e D-D, mostram que o piso do nível superior foi entalhado, deixando patamares laterais preservados. Estes patamares são protuberâncias que evidenciam antigos níveis de pisos, que podem ser correlacionados de um lado e outro da parede, em vários locais. 
O nível inferior é constituído por três galerias maiores com direções N40E, N60E e N45W. Estas galerias possuem larguras que variam entre 2 a $4 \mathrm{~m}$ e altura máxima de $3 \mathrm{~m}$. Outras pequenas galerias com altura máxima de $1,0 \mathrm{~m}$ e largura variando entre 0,7 e $1,5 \mathrm{~m}$, ocorrem secionando principalmente as galerias com orientação NE-SW. O conjunto de galerias do nível inferior compõem um padrão morfológico em rede e localmente entrelaçado.

As seções transversais no nível inferior exibem morfologia de canyon vadoso, com teto plano-inclinado, em função da presença de camadas de sílex capeando o teto, com espessura entre 20 a $30 \mathrm{~cm}$. As camadas de silex, comumente intercaladas nos carbonatos, tem a propriedade de impedir a progressão vertical dos condutos por proteção à corrosão pela água.

As cúpulas de corrosão exibem formas que variam de acordo com a razão largura/profundidade e estão presentes, mais freqüentemente, nos condutos do nivel superior. As cúpulas, em que a profundidade não varia, são classificadas de simples, enquanto as que possuem profundidade aumentando das bordas para o centro são chamadas de cúpulas em níveis (Slabe, 1995). As cúpulas nos cortes B-B' e C-C' são do tipo em níveis e possuem largura entre 4 a $4,5 \mathrm{~m}$ e altura entre 1,5 a $4 \mathrm{~m}$, que varia do centro para as bordas. No centro destas cúpulas ocorrem estalactites com até $3 \mathrm{~m}$ de comprimento, alinhadas na direção das fraturas. As cúpulas nos cortes H-H' são do tipo simples e possuem cerca de $1 \mathrm{~m}$ de largura e $3,5 \mathrm{~m}$ de profundidade, sendo mais profundas que as cúpulas simples das seções b-b' e c-c' com profundidade média de $1 \mathrm{~m}$.

\section{Condicionamento estrutural da morfologia}

As principais orientações de passagens de cavernas neste setor ocorrem nos intervalos N30-40W e N50-60E de acordo com o histograma de direção (Anexo 7A). O intervalo de direção N50-60E predomina no histograma de comprimento, seguido dos intervalos N70-80E, N40-50E e N10-20W (Anexo 7B).

As galerias seguem aproximadamente o sentido de mergulho dos planos de acamamentos da rocha. As fraturas têm ocorrência maior no teto do nivel superior, com comprimento variando acentuadamente entre 2 a $40 \mathrm{~m}$. Os principais intervalos de direções encontradas para estas fraturas são N40-50W e N40-50E, seguidos pelas fraturas nos intervalos N30-40E (Anexo 7C). No mapa do nivel superior, observa-se que os canyons e cúpulas de corrosão seguem claramente a orientação de fraturas NE-SW.

Existe uma concordância geral entre os histogramas de orientação das fraturas e da orientação dos segmentos de cavernas. O teste estatístico K-S, apoia a hipótese de correlação da distribuição da orientação entre estas populações de dados. 


\section{Paleorrotas de fluxo e preenchimento sedimentar}

As medidas de paleocorrentes feitas a partir de marcas de corrente no nivel superior, indicam que o fluxo de água estava orientado da entrada do setor, para os ramos distributários da Santa Rita e Lapa D’Água, respectivamente a SE e SW.

Com o rebaixamento do nivel de água na galeria, a paleodrenagem passou a entalhar preferencialmente o ramo da Lapa D'Água com fluxo orientado de NE para SW, vindo a abandonar o ramo da Santa Rita, que por sua vez, permaneceu preenchido por sedimento. Isto pode ser evidenciado pelas escarpas de erosão nos sedimentos do piso e pelos canyons na base do ramo da Lapa D’Água.

O desnivel entre as bordas dos canyons e o topo das pilhas de sedimento é de $8,5 \mathrm{~m}$, de acordo com o corte 5-00 e aproximadamente $10 \mathrm{~m}$ no corte 00-3. Este desnível corresponde a espessura do sedimento que preenchia a galeria antes da erosão.

A drenagem que prosseguia via os canyons que seguem a direção de fraturas, com fluxo orientado de NE para SW, interceptou as galerias do nível inferior, tendo formado quedas d'águas com altura de 6 e 4m, como sugere a morfologia dos cortes C-C' e E-E'. Em decorrência disso, houve uma erosão remontante do piso do nível superior, devido ao recuo das quedas d'água. O fluxo neste local, consiste num desvio da rota de paleofluxo geral da caverna que é NW para SE, provavelmente por conta do seu condicionamento estrutural por fraturas com direção NE-SW.

O nivel inferior é composto por três galerias maiores: duas delas com direção NE-SW e uma outra com direção NW-SE. Estas galerias possuem uma grande quantidade de pequenas entradas transversais de condutos sugerindo padrão morfológico entrelaçado.

As rotas de paleofluxo neste setor divergem daquelas observadas no nível superior. $O$ fluxo nas galerias maiores orienta-se para NE e depois para SE, no sentido de um lago que constitui o nivel de base local. Esta última rota é condizente com o sentido de fluxo geral da caverna.

Nos condutos menores o fluxo chega a convergir para as galerias maiores como verificado na porção NW do setor, ou mesmo atravessar estas galerias, como acontece na porção SE.

A diversidade de rotas observadas em ambos os níveis, está provavelmente relacionada ao realinhamento do fluxo para a rota geral de NW para SE, após a passagem das galerias com direção NE-SW, condicionada por estruturas. O fluxo que seguia por estes condutos, convergiam para o Lago da Lapa D’Água a SE (fig. 4.1). 


\section{2 .2 - Setores mapeados no Sistema Lapa da Torrinha}

O Sistema Lapa da Torrinha está situado a sudeste do Sistema Lapa Doce, também na porção central da área. A sua entrada principal localiza-se no vilarejo homônimo na base de uma grande depressão fechada, a cerca de 700m a noroeste da BR-330 (fig. 2.3). O sistema estende-se para SE e passa por baixo da rodovia em direção ao vilarejo da Santa Rita.

A malha de condutos possui direção geral NW-SE, localmente com direções NE-SW e N$\mathrm{S}$ compondo condutos com diferentes dimensões, posicionados em alturas distintas (fig. 4.2). $\mathrm{O}$ padrão morfológico geral do sistema em planta é caracterizado por condutos maiores com ramificações distributárias. Em determinados setores a nível das ramificações, são reconhecidos padrões de condutos em rede e entrelaçados.

Dentre os condutos mais extensos, destacam-se dois tipos. Um deles é caracterizado por galerias maiores ou galerias principais, originalmente com cerca de 15 a 50 de largura e 12 a $20 \mathrm{~m}$ de altura, que encontram-se modificadas por processos de incasão na maior parte do sistema. Nos trechos modificados destas galerias ocorrem salões de abatimento com largura variando entre 70 e $120 \mathrm{~m}$ e piso constituído por grandes empilhamentos de lajes e blocos de rocha.

O outro tipo de conduto é consideravelmente menor e possui 3 a $12 \mathrm{~m}$ de largura e 2 a $4 \mathrm{~m}$ de altura, consiste de ramos distributários que truncam as galerias principais em vários trechos do sistema. Na junção dos dois tipos de condutos, ocorrem expressivas escarpas em sedimentos, entre outras feições de relevo como conjuntos de pendants e pilares com aspecto de karrens (fig. 4.11).

O mapeamento topográfico e estudo morfológico do sistema foram concentrados em três trechos de condutos, situados na parte central e sudeste do mesmo. Estes setores do sistema, compreendem condutos que não sofreram grandes alterações na sua morfologia por processos de incasão. Os setores Conduto do Chifre (Setor 7) e Conduto do Vermão (Setor 8) estão inseridos num extenso conduto distributário que trunca a base das galerias maiores, e o Setor CaóticoSalão do Vale (Setor 9), abrange diferentes tipos morfológicos reconhecidos no sistema.

\section{Setor do Conduto do Chifre}

O setor do Conduto do Chifre encontra-se localizado a cerca de $500 \mathrm{~m}$ da entrada principal do sistema Lapa da Torrinha e corresponde a um pequeno trecho medindo $188 \mathrm{~m}$ de extensão, no 
nível inferior de galerias. O trecho mapeado é formado por dois segmentos maiores com orientações $\mathrm{N} 40 \mathrm{~W}$ e N45E, caracterizando uma inflexão brusca do conduto que tem direção geral N30W. O segmento N40W possui $130 \mathrm{~m}$ de comprimento, enquanto o segmento N45E possui apenas 30m de comprimento (Anexo 8).

\section{Morfologia}

O setor está localizado em contexto geral, num conduto que apresenta padrão sinuoso, caracterizado pela alternância de trechos maiores retilíneos com inflexões curvilíneas e/ou angulosas. $\mathrm{O}$ trecho mapeado compreende um pequeno segmento de conduto situado numa zona de inflexão angulosa do conduto maior.

O conduto principal é mais estreito fora da zona de curvatura, onde possui largura entre 5 e $8 \mathrm{~m}$, sendo mais largo nas proximidades da curvatura, com largura entre 8 e $11 \mathrm{~m}$. Os pequenos condutos laterais localizados na zona de curvatura estão orientados para N40W e N70E, com larguras variando entre 1 e $2,5 \mathrm{~m}$.

A morfologia dominante no grupo de seções transversais a-a' a h-h' é a elipsoidal (fig. 4.12). As seções i-i' a 1-l', correspondem a canyons com morfologia triangular, estreitos no topo e largos na base. A altura destas seções varia em função da presença de fraturas e cúpulas de corrosão no teto. No conduto principal a altura varia entre 1,8 a $3,5 \mathrm{~m}$, enquanto nos trechos não preenchidos por sedimento em condutos estreitos, a altura da galeria varia entre 3,7 e $6,7 \mathrm{~m}$.

Os pequenos condutos na zona de curvatura seguem a direção das fraturas, até ficarem parcialmente entupidos por sedimento. $O$ teto destes condutos é 1 a $2 \mathrm{~m}$ mais altos que o teto da galeria principal, por conta da presença de cúpulas de corrosão e fraturas alargadas no teto. Essa diferença é notada também no corte $\mathrm{f}-\mathrm{f}^{\circ}$, onde o teto do conduto possui localmente altura entre 3 e $3,5 \mathrm{~m}$, por conta da presença de cúpulas de corrosão, ao invés da altura média de $2 \mathrm{~m}$ no restante do conduto.

\section{Condicionamento estrutural da morfologia}

A maior freqüência de segmentos de cavernas ocorre nos intervalos N40-50W, seguida dos intervalos N30-40W, N50-80W e N40-50E, de acordo com o histograma de direção (Anexo $8 \mathrm{~A})$. As orientações predominantes no histograma de comprimento ocorrem nos intervalos N4060W e secundariamente N40-50E, N70-80E e N60-80W (Anexo 8B). 


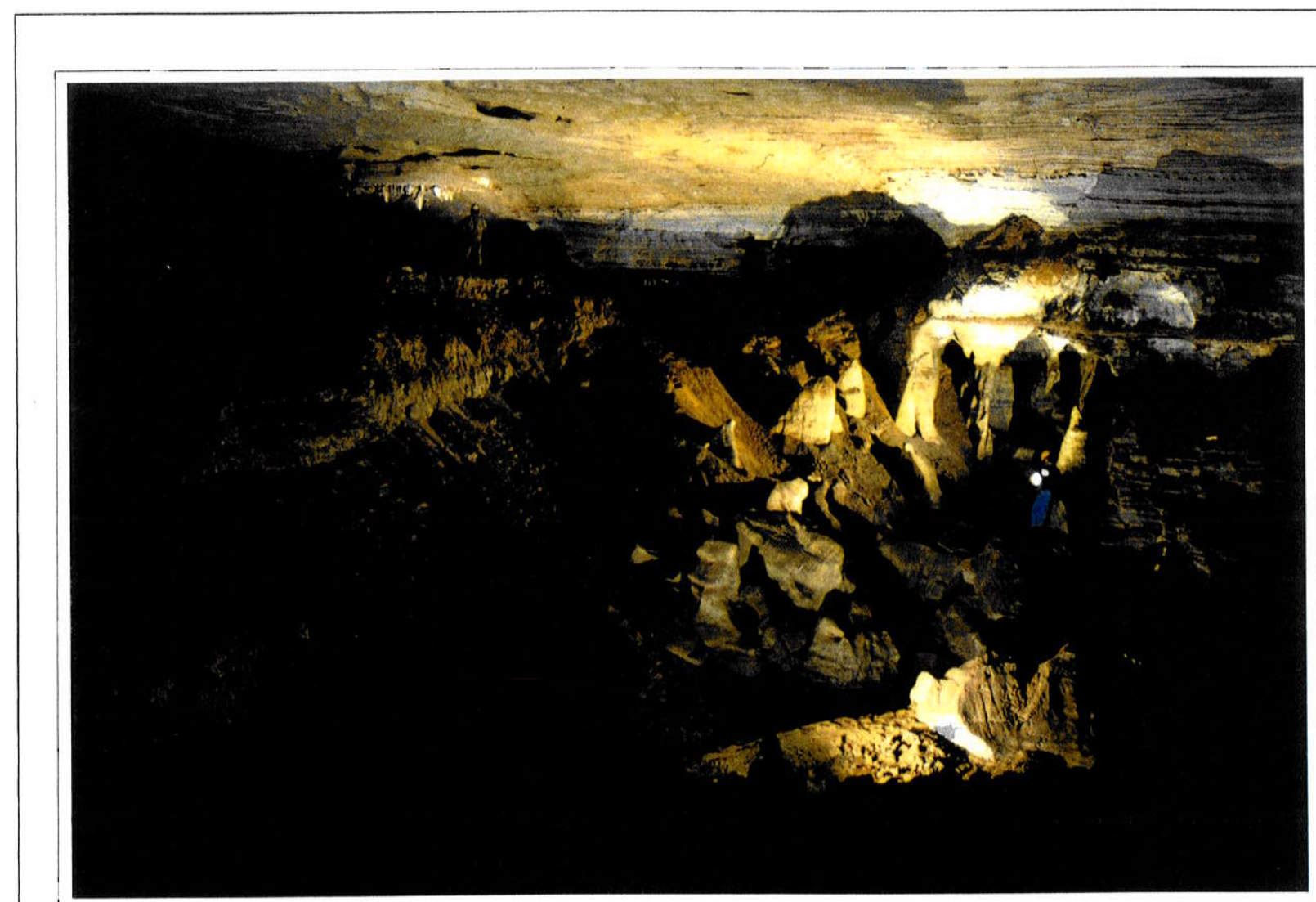

Fig. 4.11 - Escarpas em sedimentos e conjuntos de pendants e pilares com aspecto de karrens na junção entre condutos do Sistema Lapa da Torrinha. Foto de Ivo Karmann.

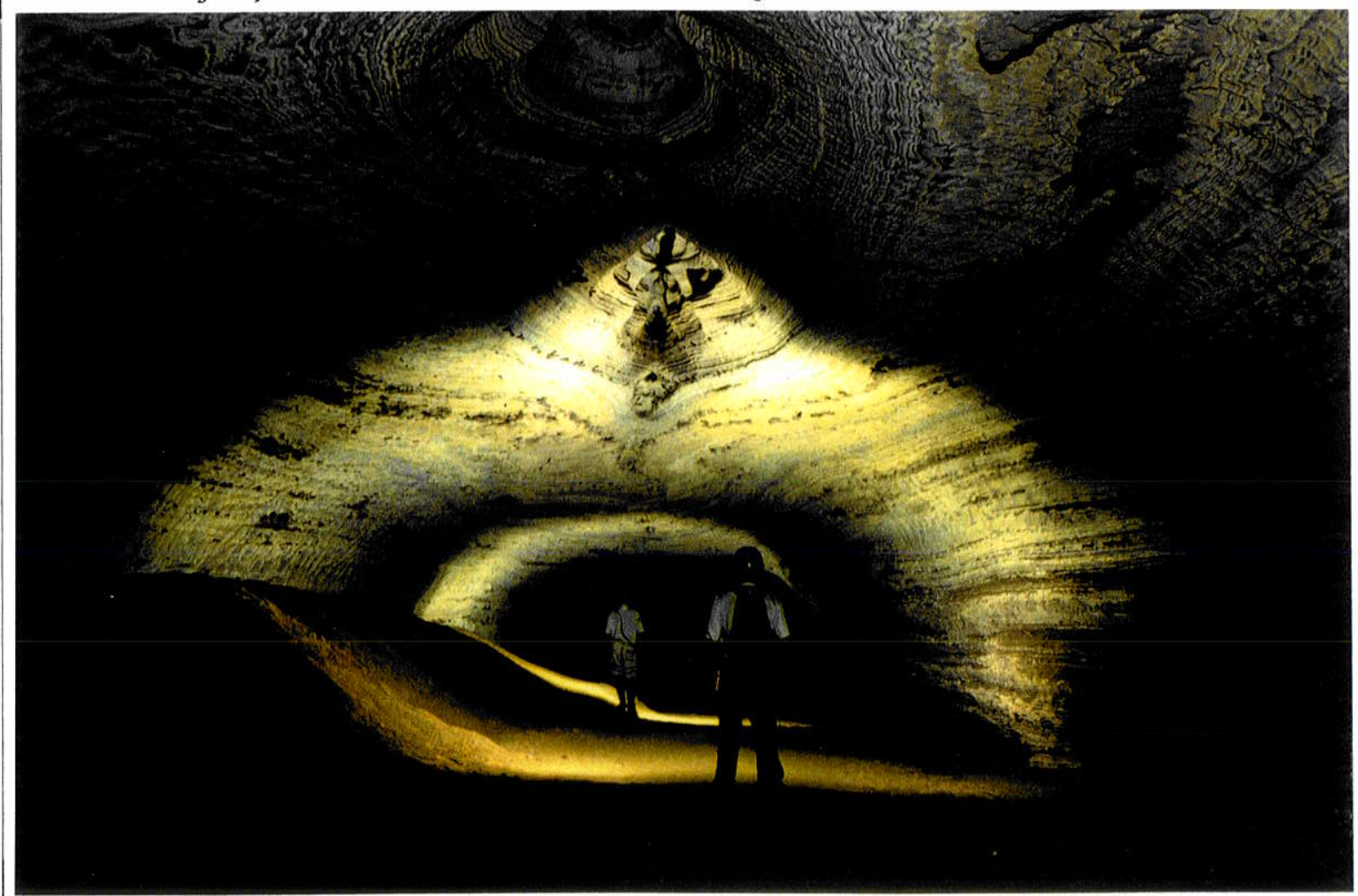

Fig. 4.12 - Conduto com morfologia elipsoidal e cúpulas de corrosão no teto, Setor 7, Conduto do Chifre. Foto de Ivo Karmann. 
Os traços de fraturas estão concentrados preferencialmente nos intervalos N30-40W e secundariamente N40-70W (Anexo 8C). Elas ocorrem com tamanho variando entre 2 a 20m. As maiores são paralelas ao trecho do conduto principal com orientação $\mathrm{N} 40 \mathrm{~W}$ e aos pequenos condutos laterais e transversais ao trecho N45E do conduto. Neste trecho do conduto, as fraturas dispostas no centro do conduto são aproximadamente paralelas as paredes, sendo que envolta delas desenvolvem-se as cúpulas de corrosão com altura variando entre 0,5 e 1,0m.

A correlação entre a orientação da população de fraturas e segmentos de passagens de cavernas pode ser sugerida para alguns trechos de condutos, diretamente pelo mapa (Anexo 8) ou a partir dos intervalos de direção dos seus respectivos histogramas. O segmento N45E, não segue a orientação de estruturas geológicas.

O teste de correlação K-S não pode ser adequadamente utilizado neste caso, pois os dados estão em pequeno número e encontram-se concentrados em poucas classes.

\section{Paleorrotas de fluxo e preenchimento sedimentar}

As rotas de fluxo estão orientadas de NW para SE no trecho do conduto N40W e nos condutos laterais. No trecho de conduto $\mathrm{N} 45 \mathrm{E}$, o fluxo segue a orientação SW para NE e mos condutos laterais prossegue o sentido da rota anterior de NW para SE.

A presença de fraturas na zona de curvatura, favoreceu provavelmente a abertura dos pequenos condutos, numa tentativa de prosseguimento da rota NW para SE. As extremidades dos condutos conservam o preenchimento sedimentar até próximo de seus tetos, enquanto em outros locais este sedimento foi erodido.

\section{Setor do Conduto do Vermão}

O setor mapeado está localizado na porção centro-sudeste da caverna Lapa da Torrinha e compõem cerca de $613 \mathrm{~m}$ de galerias, com direção geral NW-SE (Anexo 9). Devido à variedade morfológica deste setor, sua descrição foi compartimentada com base nas principais ramificações de condutos.

\section{Morfologia}

No mapa (Anexo 9), estão assinalados os principais pontos de ramificação de condutos, denominados de $R_{1}, R_{2}, R_{3}$ e $R_{4}$. 
O segmento 1, possui direção NW-SE e inicia-se na galeria de acesso a entrada principal da caverna, na porção noroeste do setor e termina no ponto $R_{2}$, atravessando o segmento 2 . $O$ segmento 2 , inicia-se em um trecho de conduto parcialmente preenchido por sedimento com direção NE-SW e segue para NE, na direção de grandes salões de abatimentos. $\mathrm{O}$ segmento 3 prolonga-se de $R_{2}$ para $R_{3}$, em um pequeno trecho com cerca de $35 \mathrm{~m}$, na direção NW-SE. $O$ segmento 4 é composto por trechos de galerias em diversas direções que inicia-se em um conduto sinuoso parcialmente entupido, próximo a $R_{3}$. Este segmento bifurca-se em $R_{4}$, num ramo orientado para SSE que segue em direção ao conduto principal da caverna e o outro acessa a SE, uma malha labiríntica de condutos com padrão em rede.

A morfologia em planta do setor é de condutos sinuosos, geralmente mais largos nos locais onde ocorrem junções de condutos e mais estreitos nos demais pontos, com tendência a formar trechos com ramificações em rede mais para leste do setor.

Os pequenos condutos laterais estão presentes principalmente no segmento 4 e ocorrem próximo à junção dos condutos ou em locais onde o conduto está inflexionado. Eles possuem largura entre 0,5 e $2 \mathrm{~m}$ e altura inferior a $1 \mathrm{~m}$ e de um modo geral estão inseridos na base dos condutos principais e tendem a se afunilar em profundidade, tornando-se mais estreitos conforme se afasta de sua entrada.

Em seção transversal predominam condutos com morfologia elipsoidal, sendo comum a presença de cúpulas de corrosão e canais freáticos no teto. Os segmentos $1,3,4$ e 5 apresentam forma aproximadamente semelhante e com dimensões parecidas (Anexo 9). A altura dos condutos varia nas seções entre 1,8 e $4 \mathrm{~m}$, com média de $2,6 \mathrm{~m}$ (25 medidas). Já os condutos com morfologia de canyons, aparecem em porções restritas do setor.

As cúpulas de corrosão no teto das galerias, são caracterizadas nas seções por reentrâncias cônicas com altura máxima entre 2 e 2,5m e largura máxima entre 1 e 2,5m, como mostram as seções $t-t^{\prime} e \mathrm{u}-\mathrm{u}$. No entanto, a maior parte destas feições possuem altura e largura inferior a $0,5 \mathrm{~m}$.

Os pendants neste setor, ocorrem em trechos do teto geralmente revestidos por finas camadas de sílex, a exemplo das seções $x-x^{\prime}$ e $z-z^{\prime}$. Estas feições são protuberâncias, que correspondem a testemunhos residuais de erosão ascendente, preservados no teto (fig. 4.13). $\mathrm{O}$ relevo do teto pode variar entre 0,6 e $1 \mathrm{~m}$, em seções com pendants. 
As seções transversais g-g'a $k-k^{\prime}$ no segmento 2 ressaltam um canal entalhado no teto (fig. 4.14). A altura da galeria nestas seções é maior do que nos demais segmentos do setor, porém depende do nivel de preenchimento de sedimento no assoalho. Nas porções do conduto onde o sedimento foi mais erodido, o conduto possui altura que varia de 4 a $7 \mathrm{~m}$ e nos locais com maior preenchimento, a altura varia entre 0,5 e $3 \mathrm{~m}$.

Os perfis longitudinais $P_{1}$ e $P_{2}$ (Anexo 9), levantados entre os pontos de ramificações de condutos $R_{1}, R_{2} \in R_{3}$, caracterizam condutos com diferentes morfologias. O perfil $P_{1}$, corresponde a um conduto com direção NW-SE, que trunca um outro com direção NE-SW, representado pelo perfil $\mathrm{P}_{2}$. $\mathrm{O}$ ponto de ramificação $\mathrm{R}_{3}$, é um local onde o truncamento de condutos com diferentes morfologias é bastante evidente (fig. 4.15).

Os trechos com maior altura coincidem com as junções entre condutos, conforme visualizado no perfil $P_{1}$. Os segmentos 1 e 3 no $P_{1}$ possuem altura média de $2 \mathrm{~m}$, no entanto, apresentam desniveis de teto, variando entre 3,5 e 4,8m, na zona de interseção, em relação ao conduto representado pelo segmento 2 .

$O$ conduto do segmento 2 no perfil $P_{2}$, inicia-se a SW com altura de $0,5 \mathrm{~m}$, apresentando teto e piso aproximadamente planos. Este conduto mantém o teto plano até alcançar os pontos de ramificação $R_{1}$ e $R_{2}$, onde o teto torna-se suavemente ondulado. $O$ relevo do piso é bastante dissecado, com desniveis de $5,5 \mathrm{~m}$, verificados entre o piso no extremo $\mathrm{SW}$ e na junção de condutos em $R_{1}$ e $R_{2}$. Nota-se que o piso ao longo do perfil $P_{1}$, representa o nível mais baixo do piso do perfil $\mathrm{P}_{2}$.

\section{Condicionamento estrutural da morfologia}

A maior freqüência de segmentos de condutos estão concentradas preferencialmente nos intervalos N10-20W, seguida do intervalo $\mathrm{N}$ a N10W do histograma de direção (Anexo 9A). Já no intervalo N10-20W, seguido dos intervalos N60-70W, N60-70E, N a N30W predominam no histograma de comprimento (Anexo 9B).

Os traços de fraturas mapeadas possuem dimensão variando entre 1 a $30 \mathrm{~m}$ e são retilíneos e localmente sinuosos. Estes traços concentram-se no intervalo N40-50W, seguido do intervalo N70-90E (Anexo 9C).

A comparação entre os histogramas com a orientação de segmentos de condutos e fraturas mapeadas sugere que não existe correlação na distribuição das duas populações de dados. O teste estatístico K-S, confirma que se tratam de distribuiçōes não coincidentes de dados. 


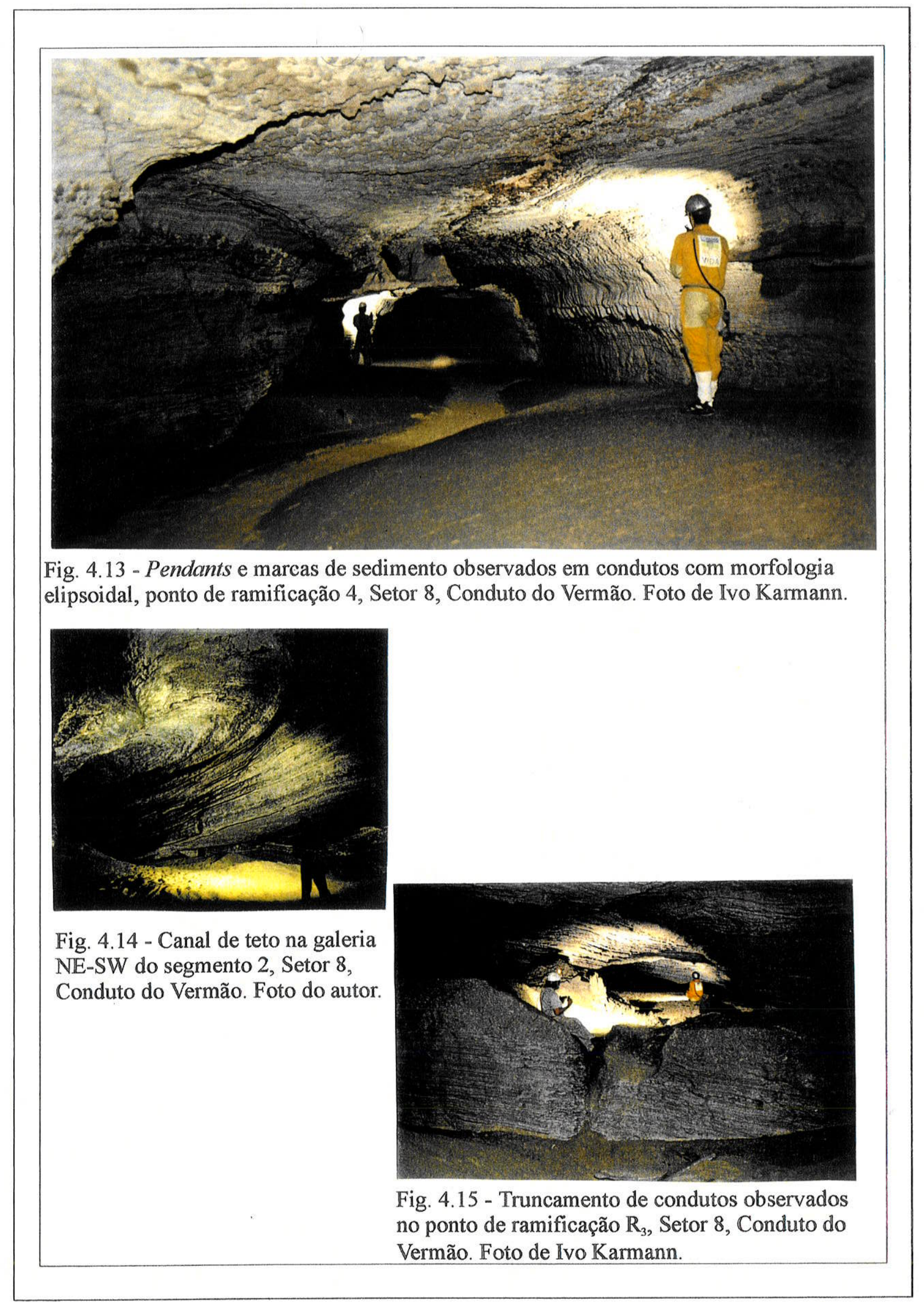


A falta de correlação entre a orientação de fraturas e condutos representa o quadro geral dos condutos de grandes dimensões, sendo que, localmente, nos pequenos condutos laterais, nota-se uma nítida coincidência com estas estruturas.

O condicionamento no desenvolvimento de feições de dissolução pela orientação de estruturas tectônica, é mais evidente na maior parte das cúpulas de corrosão. Em planta, as fraturas geralmente estão dispostas no centro das cúpulas e em perfil estão posicionadas na parte mais profunda das seções.

Os planos de acamamentos possuem suaves mergulhos de 4 a $5^{\circ}$ para NE ou SE e raramente para SW. Sua direção concorda localmente com a orientação de condutos.

As falhas normais são outras estruturas mapeadas no setor e ocorrem sempre em direções transversais as paredes dos condutos.

\section{Paleorrotas de fluxo e preenchimento sedimentar}

O levantamento de marcas de corrente indica uma rota de fluxo mais antiga com sentido para NE, representada por setas duplas, associada a condutos parcialmente preenchidos por sedimentos. As setas simples indicam rotas com sentido de fluxo para SE, que estão relacionadas a condutos desobstruídos, caracterizados por marcas de sedimento no teto e escarpas em sedimento dispostas lateralmente ao seu prosseguimento (Anexo 9).

\section{Setor Caótico e Salão do Vale}

O Salão do Vale e Setor Caótico estão localizados no extremo SE do Sistema Lapa da Torrinha. Ao todo foram mapeados $550 \mathrm{~m}$ de condutos nesta porção do sistema de caverna (Anexo 10).

\section{Morfologia}

O Salão do Vale corresponde a um trecho da galeria principal da Caverna Lapa da Torrinha com direção N-S, comprimento de $250 \mathrm{~m}$ e largura entre 20 e $35 \mathrm{~m}$. Este trecho da caverna encontra-se parcialmente obstruído nas suas extremidades sul e norte, onde ocorrem represas de travertinos e escorrimentos de calcita sobre sedimentos clásticos. O Salão do Vale está interligado com outros condutos posicionados altimetricamente em cotas inferiores ao teto e piso do conduto principal.

$\mathrm{Na}$ porção norte, especificamente no Salão da Junção individualiza-se três conjuntos morfológicos distintos: o Condutos do Vermão, o Conduto Paralelo e a galeria principal (Anexo 
10, seção c-c'). O Conduto do Vermão ocorre truncando a base da galeria principal e do Conduto Paralelo A galeria principal neste trecho possui um grande volume de blocos abatido sobre sedimentos que chega a formar escarpas com cerca de $8 \mathrm{~m}$ de altura.

O Conduto do Vermão na porção norte da gruta é caracterizado por larguras variando em planta entre 5 e $7 \mathrm{~m}$ e alturas entre 2,5 e $3 \mathrm{~m}$, com predomínio de morfologia elipsoidal em seção transversal, de acordo com os seções a-a' e b-b'.

O Conduto Paralelo, a propósito de sua denominação, possui a mesma direção do Conduto Principal, assim como o Conduto do Castelo, situado na parte central do mapa (Anexo 10). Ele possui largura entre 3 e $4 \mathrm{~m}$ e altura entre 8,5 e $9 \mathrm{~m}$. Nas seções transversais d-d' e e-e' em planta é observado o contorno de canal de teto semelhante ao descrito no setor 8 , que percorre quase todo o conduto paralelo, e inflexiona-se para W, na direção de um conduto entupido. No lado leste do Conduto Paralelo, aparecem ramos de condutos menores entrelaçados, conjugados por uma única parede secionada em diversos pontos, caracterizando pilares. Estes condutos possuem altura variando entre 1,5 e $3 \mathrm{~m}$ e largura de 3 a $4 \mathrm{~m}$ e estão parcialmente entupidos por sedimentos. Junto ao Salão do Vale estão preservados pedaços da parede do Conduto Paralelo (seção $g-g^{\prime}$ ), que são testemunhos da erosão que destruiu a maior parte do conduto neste trecho. $O$ teto do conduto pode ser delineado através dos cortes $f-f^{\prime}, h-h^{\prime}$ e $g-g^{\prime}$.

No setor há condutos quase totalmente preenchidos por sedimentos e outros em que ocorrem escarpas dispostas entre o topo deste preenchimento e o seu nível de erosão mais recente. Os sedimentos distribuem-se no piso das galerias e ao longo de testemunhos, os quais ocorrem como vertentes, que caracterizam o evento de erosão do preenchimento sedimentar ao longo da rota de fluxo mais recente. As escarpas traçadas em planta estão localizadas nas junções e extremidades de condutos e evidenciam o preenchimento quase total da maior parte dos condutos (fig. 4.16). $\mathrm{O}$ topo do preenchimento é marcado por uma fina camada de sedimentos argilo-arenosos apresentadas em planta por tonalidades de cinza mais escuras. Esta camada apresenta espessura decimétrica nos condutos laterais e possui de 3 a $4,5 \mathrm{~m}$ no Salão do Vale, onde está caracterizado um patamar suavemente ondulado, com altura de $4 \mathrm{a} 6 \mathrm{~m}$ do teto.

Os desníveis entre o topo dos testemunhos de sedimento e a superficie de erosão mais recente, é de $8 \mathrm{~m}$, na seção c-c', 10 a $11 \mathrm{~m}$ nos cortes h-h' e i'-i'. A base do corte j-j', corresponde ao piso plano do vale encaixado nos sedimentos ao centro do Salão do Vale, que liga-se com o Setor Exótico a leste e ao Conduto do Castelo a oeste, caracterizando a superfície de eroção mais recente (fig. 4.17). 


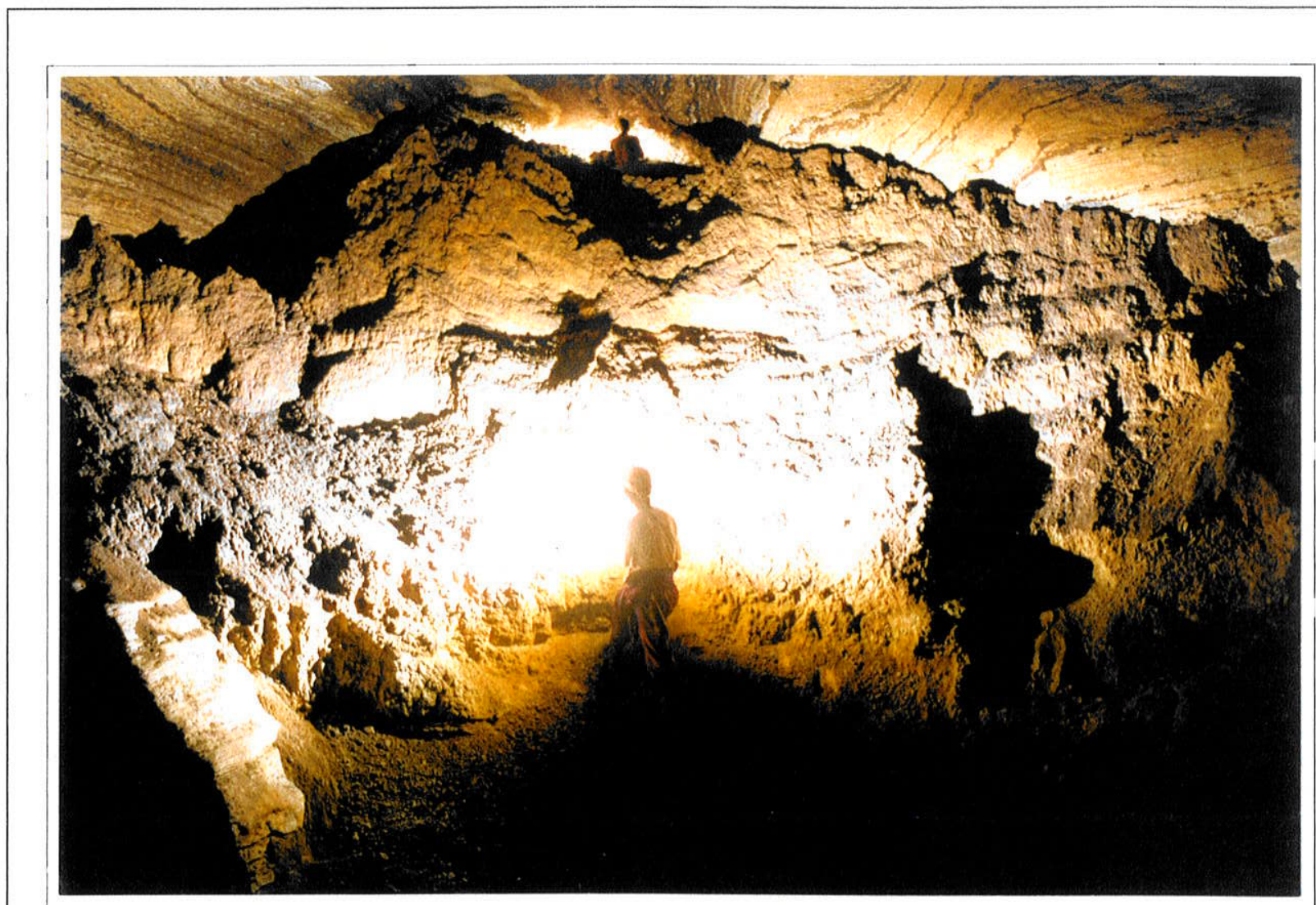

Fig. 4.16 - Conduto quase totalmente entupido por sedimentos clásticos, Setor 9, Caótico. Foto do autor.

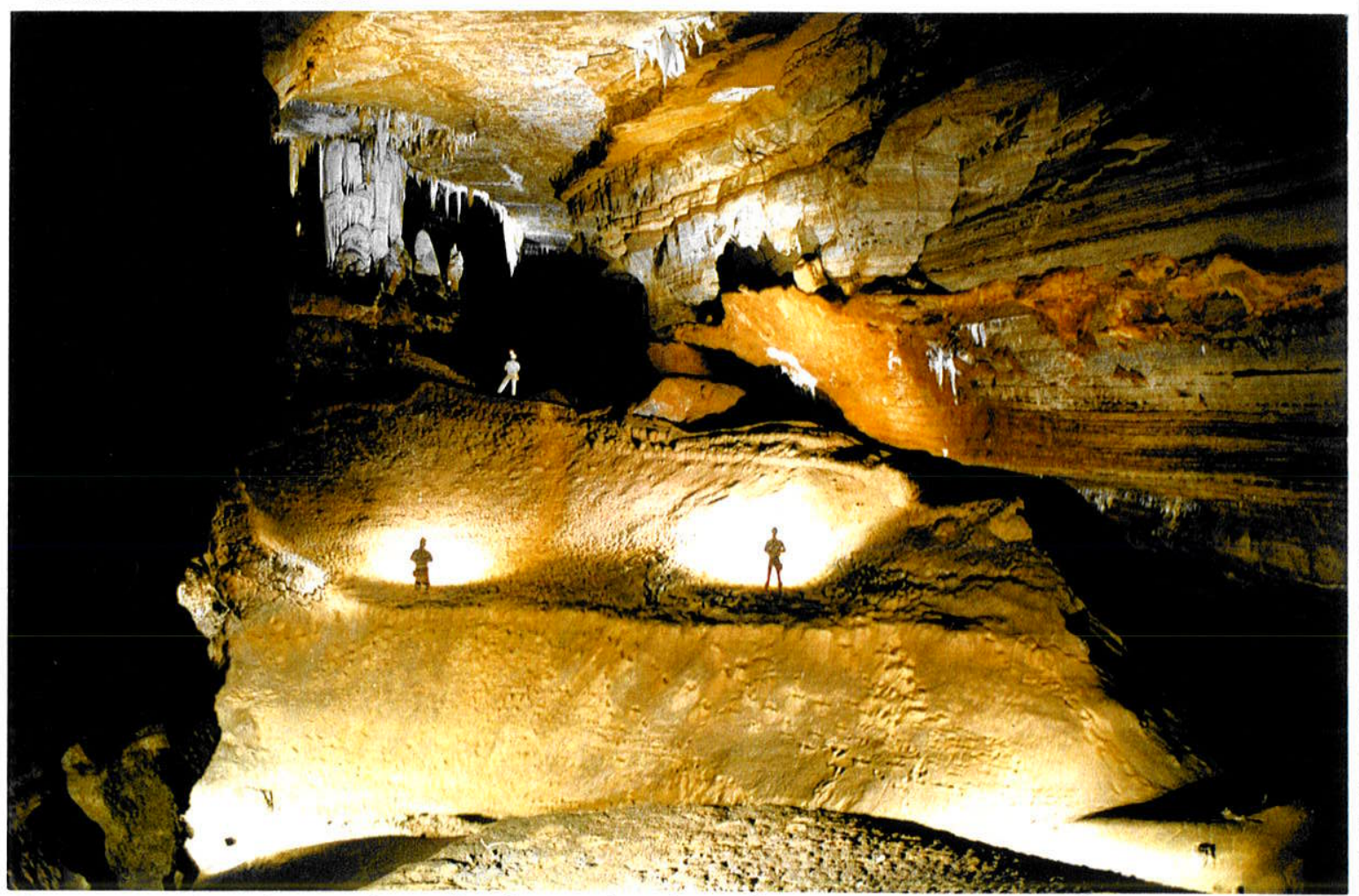

Fig. 4.17 - Vista do canal entalhado no piso de sedimento, crostas de sedimento e pendants junto ao teto do Salão do Vale, Setor 9. Foto do autor. 
A inclinação das escarpas de sedimento varia acentuadamente nas seções e perfis longitudinais. Na seção $h$-h' e no vale ao centro do perfil longitudinal 2, a inclinação das escarpas ultrapassa $45^{\circ}$, mas é suave nos cortes c-c' e i-i'.

A erosão do piso de sedimento está bem caracterizada no lado oeste do Salão do Vale, onde além das escarpas em sedimento, observam-se níveis de sedimento encrustados na parede e capas estalagmíticas depositados sobre o antigo piso. As capas estalagmíticas encontram-se suspensas na galeria, e indicam o topo do preenchimento sedimentar do conduto de uma determinada época de sua evolução (fig. 4.18).

A galeria principal do Salão do Vale é caracterizada por possuir sua morfologia original preservada em parte de sua extensão (fig. 4.17). No seu teto ocorre um canal exibindo contorno sinuoso em planta, com largura variando entre 10 e $15 \mathrm{~m}$ (Anexo10). A parede deste canal está preservada em algumas seções e apresenta alturas de 2,5m no corte i-i' a 5,5m no corte j-j'.

O perfil PL-2, demonstra que o teto do Salão do Vale é reto ao longo de todo o canal, tornando-se mais alto e irregular a sul, no trecho modificado por abatimentos. $O$ relevo do piso no perfil PL-2 apresenta trechos suavemente ondulados e um canal no piso de sedimento entalhado transversalmente a direção da galeria, que se comunica com os condutos do Setor Exótico e com o Conduto do Castelo. O conduto do Setor Exótico (fig. 4.2), que não chegou a ser mapeado no presente trabalho, continua por centenas de metros apresentando um padrão de vale encaixado em sedimentos.

A projeção do Conduto do Castelo no Perfil PL-2 indica que seu teto situa-se abaixo do nível do piso do Salão do Vale e o seu assoalho está no mesmo nível topográfico da base do canal entalhado no piso ao centro do perfil.

O Setor Caótico é composto por um conjunto de galerias que se intercruzam, caracterizando um padrão morfológico em rede com direções aproximadamente N-S e E-W. Este trecho inicia-se na parte sul do Salão do Vale no Conduto do Castelo, estendendo-se para outros setores da caverna, somando ao todo $355 \mathrm{~m}$ de galerias mapeadas. Para melhor compreensão de como foi desenvolvida esta malha de condutos, foram elaborados cortes transversais e perfis longitudinais que representam a projeção das entradas ou junções de condutos, sobre suas paredes (Anexo 10).

As áreas em branco sobre os perfis longitudinais e transversais, representam as projeção das entradas de condutos laterais no plano vertical. As áreas preenchidas, por sua vez, indicam a projeção de uma das paredes laterais, de acordo com a seta de orientação do perfil 


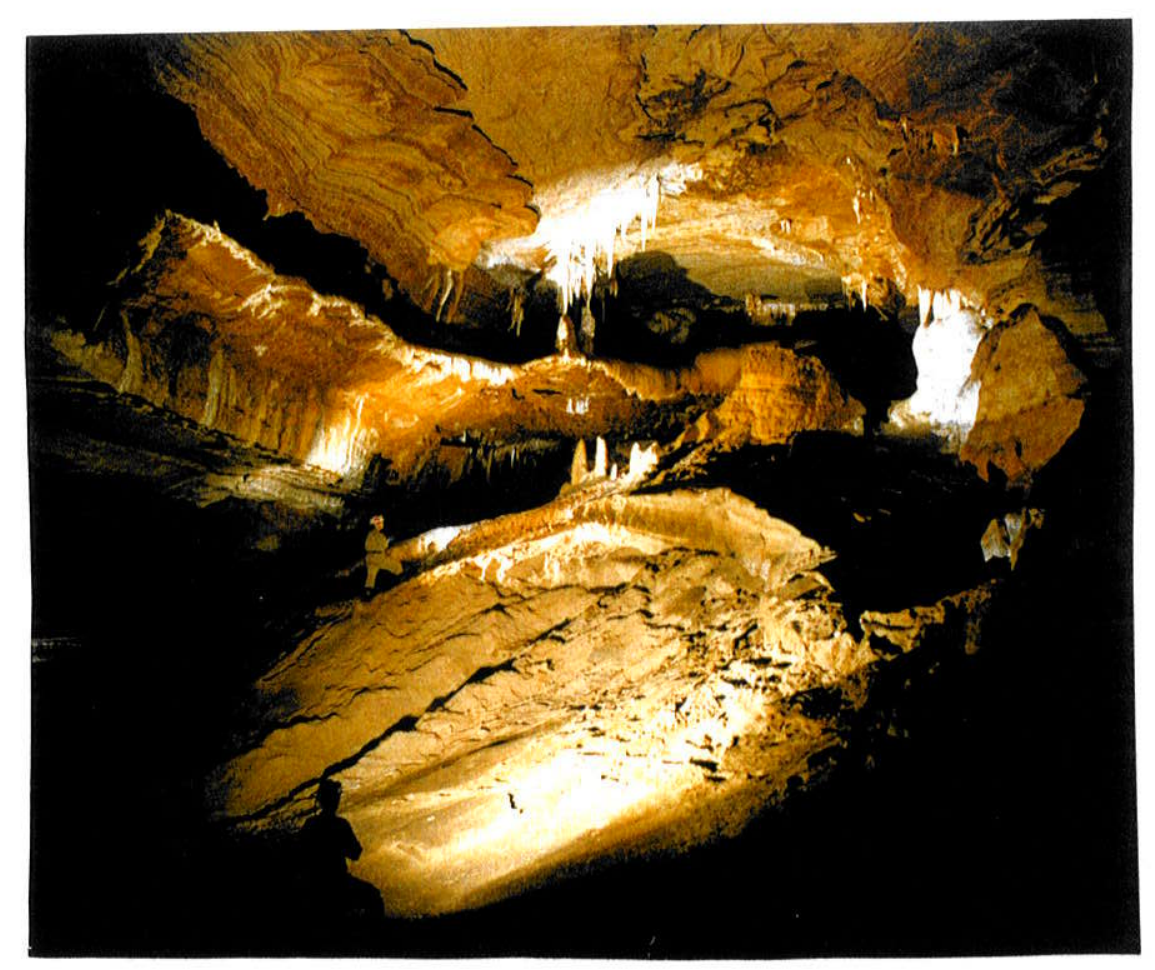

Fig. 4.18 - Capas estalagmíticas suspensas no Salão do Vale, Setor 9, indicativos de antigo nível de preenchimento sedimentar. Foto do autor.

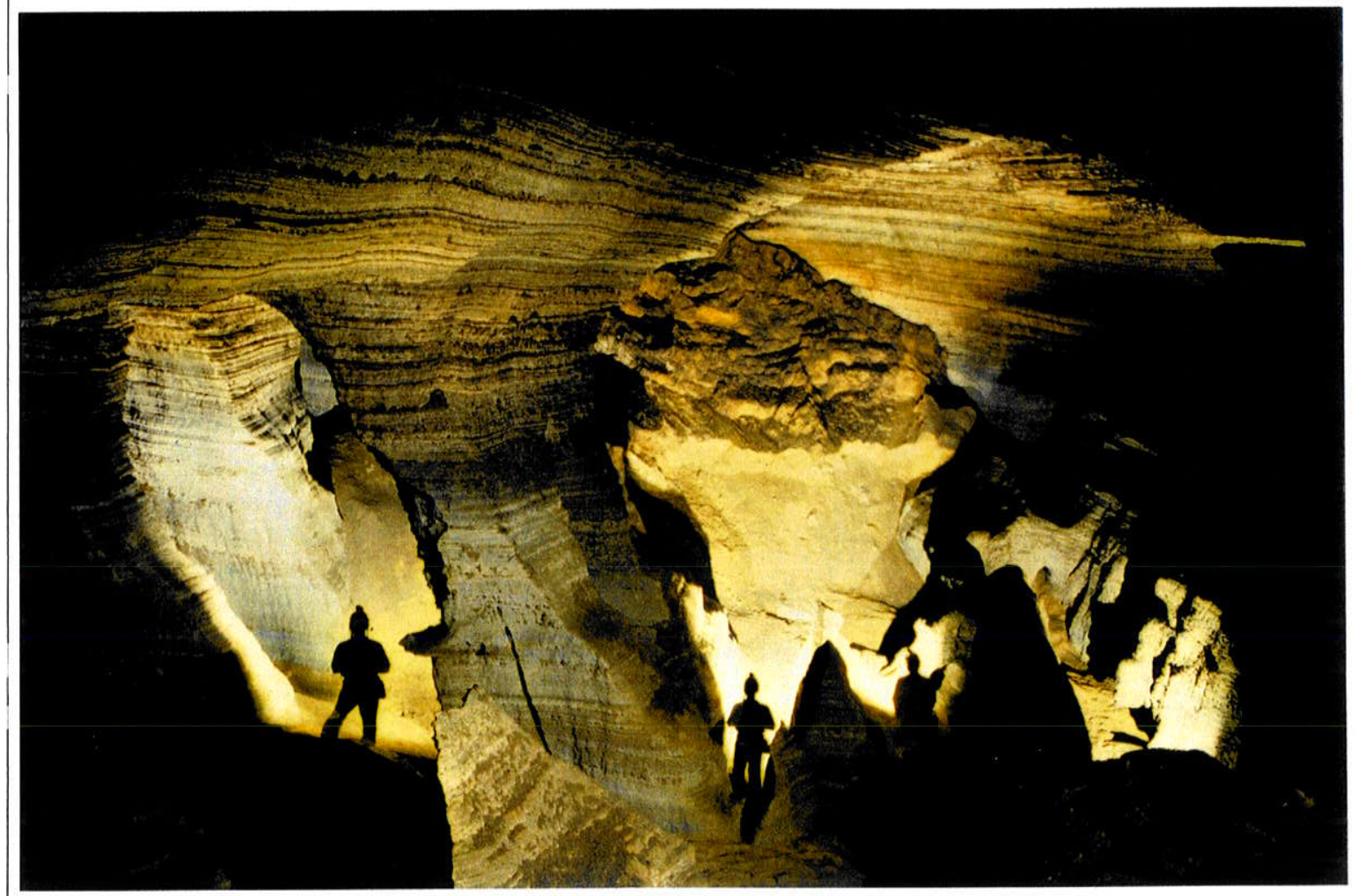

Fig. 4.19 - Conjunto de colunas, pilares e mesas com aspecto de karrens e escarpas de sedimento ao fundo, Setor 9, Caótico. Foto do autor. 
O conduto do Castelo possuí morfologia de canyon e apresenta teto e piso aproximadamente planos ao longo de toda a sua extensão (perfil PL-3). Ele é cortado transversalmente por vários condutos, com entradas situadas em diversos pontos das paredes. A altura média desse conduto é de $6,5 \mathrm{~m}$, sendo equivalente em altura e morfologia aos perfis longitudinais PL-5 e PL-6, também com teto quase planos.

A maior parte dos condutos laterais iniciam-se na base das galerias representadas nos perfis, mas alguns deles ocorrem próximo do teto do Conduto do Castelo, como mostraram as seções $1-1$ ' e m-m'. Existem locais onde o contorno da parede não está bem definido devido ao grande número de condutos laterais. Algumas junções de condutos são correspondentes em ambas paredes das galerias e outras situam-se em apenas uma de suas paredes. Testemunhos erosivos como pilares, mesas e pendants no teto, observadas por exemplo, nos perfis PL-4, PL-5 e PL-6, correspondem à restos de paredes de condutos. Em vários locais este grupo de feições apresentam aspecto de karrens formados no contato entre sedimento e rocha (fig. 4.19).

$\mathrm{O}$ contorno do teto nas seções transversais com direção aproximadamente E-W é bastante irregular, diferentemente do que é observado nos perfis longitudinais. Existe uma alternância de trechos mais altos com mais baixos. As partes mais altas correspondem ao teto dos condutos orientados segundo N-S (N10W a N10E), que interceptam as seções transversais. Já as partes mais baixas correspondem aos locais onde as paredes foram rompidas por condutos laterais, orientados genericamente na direção E-W, coincidindo com a projeção dos pilares e colunas.

$\mathrm{Na}$ parte sul do Setor Caótico foram observados escorrimentos calcíticos com evidências de erosão por fluxo de água (marcas de erosão), de acordo com as seções transversais A-A', BB', C-C' e o perfil longitudinal D-D' (Anexo 10). A base dos escorrimentos nas seções e no perfil encontra-se erodida e os espeleotemas suspensos e presos nas paredes do conduto. No perfil d-d', observa-se uma escarpa de sedimento que indica preenchimento quase total do conduto.

\section{Condicionamento estrutural da morfologia}

A maior parte dos traços de fraturas mapeados no Conduto Paralelo, Salão da Junção e Salão do Vale, estão dispostas transversalmente aos condutos principais, no entanto os traços de fraturas mapeados no Setor Caótico acompanham geralmente a orientação dos condutos.

Os intervalos de maior freqüência de orientações de segmentos de condutos são $\mathrm{N}$ a N10E e N80-90W, seguido pelos intervalos $\mathrm{N}$ a $\mathrm{N} 20 \mathrm{~W}$ e N60-80W de acordo com o histograma de 
direção (Anexo 10A). Os principais intervalos no histograma de comprimento são para N a N10E e N80-90E, seguido N10-20W (Anexo 10B). O histograma de comprimento de segmentos, concorda assim com a distribuição de classes do histograma de direção no Setor Caótico.

$\mathrm{O}$ teste estatístico K-S, demonstra que não há coincidência entre os máximos de orientação de segmentos de condutos e traços de fraturas. No entanto, observando-se os histogramas correspondentes (Anexo 10A, 10B e 10C) é possível obter uma concordância entre a orientação preferencial de condutos e traços de fraturas.

A discordância entre o resultado do teste estatístico e da comparação visual entre os histogramas de direção, é atribuída ao fato do teste limitar a correlação a intervalos de $10^{\circ}$ azimute, enquanto que o conjunto de dados apresenta uma dispersão de $20^{\circ}$ azimute.

\section{Paleorrotas e preenchimento sedimentar}

As paleorrotas de fluxo d'água são deduzidas com base no posicionamento das escarpas de sedimento mapeadas em planta, juntamente com o levantamento de marcas de corrente e características morfológicas dos condutos.

Associando as crostas, manchas e empilhamentos de sedimentos, verifica-se que todos os condutos estavam parcialmente a totalmente preenchidos por sedimentos clásticos. As escarpas de sedimentos limitam os trechos de condutos desobstruídos daqueles que ainda conservam o preenchimento detrítico.

A paleorrota de fluxo responsável pela desobstrução do preenchimento sedimentar de parte dos condutos possui sentido geral de $\mathrm{N}$ para $\mathrm{S}$, de acordo com o posicionamento das escarpas em planta (Anexo 10) e com os sentidos de paleocorrentes medidos através de marcas de corrente. Esta rota iniciava-se a norte no Setor do Conduto do Vermão, atingindo o conduto principal e prosseguindo pelo conduto paralelo, até alcançar o Salão do Vale.

Neste último local, observa-se que a rota de entalhamento dos sedimentos bifurcar-se. Uma delas prossegue no sentido geral $\mathrm{S}$, removendo parcialmente o sedimento e modificando a morfologia do conduto do Castelo e do Setor Caótico e a outra inicia-se no Salão do Vale, através de uma brusca inflexão no sentido geral para SE, indo em direção ao Setor Exótico.

Deve-se ressaltar que o evento relacionado ao entalhamento do preenchimento sedimentar no Setor Caótico e Salão do Vale, foi acompanhado pela erosão parcial das paredes de condutos, que levou a formação de uma série de junções entre condutos e testemunhos erosivos, como mesas e pilares. 
4.3 - Síntese da morfologia, condicionamento estrutural e paleorrotas de fluxo dos sistemas de cavernas estudados

Este item tem objetivo resumir as principais caracteristicas da morfologia, do condicionamento estrutural e das rotas de paleofluxo descritas nos setores de cavernas estudados.

\section{Morfologia}

\section{Padrões morfológicos planimétricos}

Os padrões morfológicos de cavernas em planta baseiam-se na geometria dos condutos e relação entre as suas paleorrotas de fluxo.

Nos sistemas Lapa Doce e Lapa da Torrinha, o padrão geral de condutos é distributário ou distributary conduits (Palmer, 1984; White \& Deike, 1989). Este padrão é caracterizado por amplas galerias ou galerias principais apresentando mais de $20 \mathrm{~m}$ de largura, a partir das quais, desenvolvem-se ramificações de condutos. $O$ mesmo padrão foi identificado inicialmente por Ferrari (1990) no Sistema Lapa Doce (fig. 4.1).

As junções entre condutos nos sistemas são definidas por ramificações de condutos distributários ou divergentes, tanto nas galerias principais, quanto nos ramos laterais, compostos por condutos menores (fig. 4.20a). As ramificações iniciam-se em alturas próximas ao piso da galeria principal ou a alguns metros de altura a partir deste. Alguns dos ramos truncam outros condutos preexistentes, como ocorre na porção SE do Sistema Lapa Doce e no conduto NW-SE onde estão situados os setores 7 e 8 (Anexos 8 e 9) no Sistema Lapa da Torrinha. Outros desenvolvem-se em alto ângulo em relação a direção dos condutos principais, a exemplo dos ramos Minotauro, Lapa do Sol e Doce situados no Setor 2 (Anexo 3).

Nos setores mapeados foram descritos, além dos padrões de ramificações distributárias, as ramificações de condutos em alça, condutos em rede, condutos entrelaçados e salões de abatimento (fig. 4.20a). O agrupamento composto pelos condutos principais e as ramificações de condutos formam as malhas labirínticas observadas na planta dos sistemas (figs. 4.1 e 4.2).

O padrão de condutos em alça ou bypass (Ford \& Ewers, 1978) é caracterizado por condutos iniciados como ramos distributários da galeria principal, que no entanto, convergem para um outro trecho a jusante da mesma galeria. Os setores 1 e 5 (Anexos 2 e 6), são exemplo de condutos deste padrão, que contornam trechos das galerias principais com altos níveis de preenchimento sedimentar e abatimentos. 
O padrão entrelaçado ou anastomotic (Palmer, 1991) é caracterizado por malhas compostas de pequenos condutos curvilíneos (fig. 4.20) que ocorrem lecalmente interligando condutos maiores, como observado no Setor 6 (Anexo 7).

O padrão em rede ou network (Bretz, 1942; Palmer, 1991) é caracterizado por trechos de condutos labirínticos que se intersectam em ângulo quase reto. Este padrão está representado principalmente através de condutos controlados por estruturas na parte sul do Setor 9 (Anexo 10) e a na porção SE do Setor 8 (Anexo 9). Algumas malhas de condutos em rede não apresentam controle estrutural aparente, a exemplo de condutos do Setor 3 (Anexo 4).

Os salões de abatimento referem-se a trechos de cavernas onde a morfologia original foi modificada por grandes abatimentos de blocos e lajes de rocha. As galerias principais, que, geralmente não ultrapassam $50 \mathrm{~m}$ de largura na morfologia original chegam a ter 100 a $110 \mathrm{~m}$ de largura em planta após o abatimento. Em alguns destes salões, os abatimentos chegam a atingir a superficie formando dolinas de colapso. As dolinas de colapso estão inseridas no grupo de depressões fechadas com perfil escarpado.

\section{Seções transversais de condutos}

Os principais tipos de seções morfológicas mapeadas foram classificadas em: canyon, elipsoidal, retangular e abatimento. A classificação das seções leva em consideração a posição relativa das paredes e a relação altura x largura, além do acúmulo de blocos e lajes no caso das seções de abatimentos (fig. 4.20b).

As terminações de topo das seções podem ser em tetos planos, geralmente quando o teto é revestido por camadas impermeáveis constituídas de sílex, tetos côncavos em condutos de morfologia elipsoidal, tetos triangulares na presença de cúpulas de corrosão controladas por fraturas e tetos semi-elípticos a semi-retangulares na ocorrência de canais de tetos (half tubes).

As seções apresentando morfologia em canyon estão representadas por diversas formas denominadas de canyon com patamares rochosos, canyon triangular, canyon com canais no teto e canyon tipo fenda (fig. 4.20b).

As seções apresentando formas de canyons com patamares rochosos são caracterizadas por testemunhos do piso rochoso preservados nas paredes de condutos. Este tipo de seção é comum nos setores 5 e 6 (Anexo 6 e 7) no Sistema Lapa Doce, onde existem trechos de piso rochosos entalhados por canyons meandrantes. Os canyons entalham somente parte do piso da galeria, preservando patamares ou resto do piso ao longo de suas bordas. 


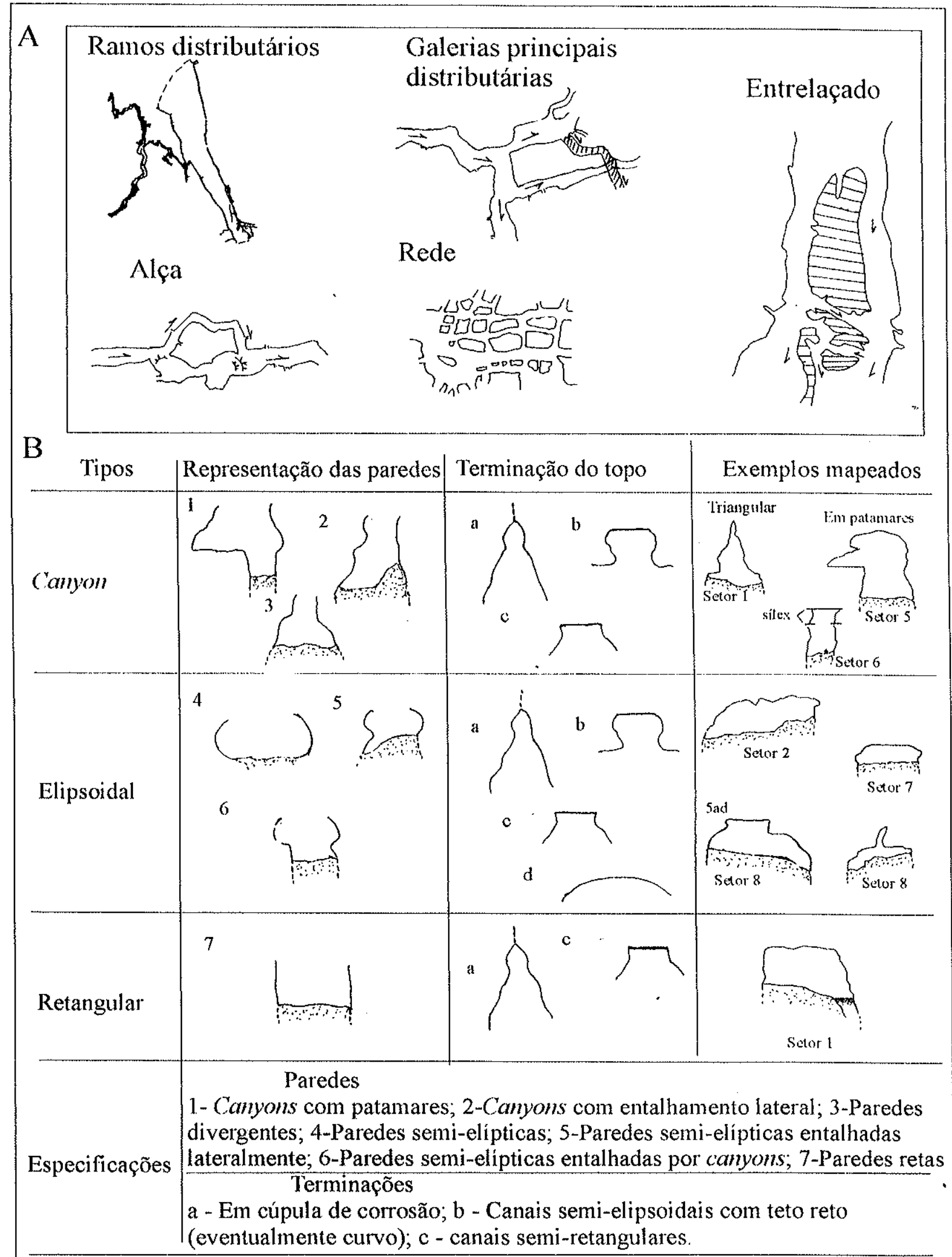

Fig. 4.20 - Quadro resumido dos padrões morfológicos de condutos: (A) padrões em planta; (B) padrões em seção transversal. 
Os canyons triangulares correspondem a condutos caracterizados por paredes com inclinações divergentes, estreitos no topo e largos na base. Nestes condutos estão presentes fraturas ou falhas no teto, que condicionam a sua direção. As cúpulas de corrosão, ocorrem quase sempre acompanhando a direção destas fraturas. Este tipo de seção predomina nos condutos do Setor 1 (Anexo 2) e em condutos de outros setores também controlados pela presença de estruturas.

Os canyons podem ocorrer também com canais de teto semi-elipticos a semi-retangulares que envolvem totalmente a superficie do teto, por vezes transversais as paredes dos condutos. Estes tipos de seções ocorrem em parte dos setores 3, 5, 8 e 9. O teto destas seções são planos em alguns condutos, a exemplo dos condutos do Setor 3 e em parte dos condutos do Setor 9 , além de vátios ramos laterais do Sistema Lapa Doce, como o ramo Lapa do Sol.

As seções apresentando morfologia elipsoidal, ocorrem em condutos semicirculares e sem canyon bem definido na base, geralmente revestidos por sedimentos. Estas seções predominam nos condutos dos setores 7 e 8 e nas galerias principais dos setores, mas também foram observadas em alguns ramos laterais de galerias, a sudeste do Sistema Lapa Doce.

As seções elipsoidais nas galerias principais dos setores 2 e 4 , ressaltam que o conduto foi modificado por entalhamento lateral, preferencialmente de um lado da galeria, onde se há reentrâncias nas paredes ou nos locais em que o piso de sedimento foi erodido.

As seções apresentando morfologia retangular, são típicas de condutos com teto revestido por camadas impermeáveis de sílex, freqüentes em condutos no nível inferior do Setor 6 (Anexo 7).

As seções de abatimento, naturalmente observadas em salões de abatimento, são caracterizadas por grandes volumes de blocos e lajes, geralmente sobre altos níveis de sedimento. As seções d-d' a g-g' situadas no Setor 2 (Anexo 3), são exemplos mapeados deste tipo de seção.

\section{Condicionamento estrutural das passagens de cavernas}

\section{Orientação de passagens de cavernas}

Os histogramas de direção e comprimento, em função dos intervalos de $10^{\circ}$ de azimute do total de segmentos medidos nas plantas das figuras 4.1 e 4.2 indicam que os segmentos estão distribuídos em vários intervalos de orientação (fig. 4.21a e b). $\mathrm{O}$ histograma de direção apresenta 
uma concentração máxima no intervalo N10-20W e secundária nos intervalos N70-80W e N60$70 \mathrm{E}$ (fig. 4.21a). Já o histograma de comprimento os intervalos preferenciais são N40-50W e N70-80W(fig. 4.21b). Nos histogramas subseqüentes relativos aos sistemas de cavernas, persistem os intervalos orientados para NW-SE, sobressaindo-se o intervalo N10-20W dos histogramas de direção.

No Sistema Lapa Doce, ocorre uma dispersão de segmentos nos histogramas de direção, preferencialmente nos intervalos N10-20W, N50-60W, N70-80W e N60-70E (fig. 4.21c). Já o histograma de comprimento de segmentos (fig. 4.21d), indica os intervalos N10-20W e N40$60 \mathrm{~W}$, como sendo os mais proeminentes. A discrepância entre os intervalos principais dos dois diagramas é devida a presença de segmentos de condutos que apesar de não serem os mais freqüentes possuem comprimento superiores a $100 \mathrm{~m}$. Os intervalos com orientação para NE, representam condutos subsidiários, dispostos transversalmente a condutos principais deste sistema.

No Sistema Torrinha, os principais intervalos de direção (fig. 4.2le), são para N10-20W, N40-50W e N70-90W e os intervalos da freqüência de comprimento são para N60-70W, N4050W e N20-30W (fig. 4.21f).

\section{Planos de estruturas geológicas}

As atitudes de planos de acamamento, juntas de cisalhamento e falhas, foram medidas nas paredes das galerias. $O$ conjunto de medidas obtidas encontra-se resumido na tabela 4.1

\begin{tabular}{|l|l|}
\hline TIPO DE ESTRUTURA & ATITUDE (S) PREDOMINANTE (S) \\
\hline PLANOS DE ACAMAMENIO & N30W/05-10NE \\
\hline FRATTIRAS DE CISAIAIAMIENTO DO TIPO 1 & N43-57W/78-87NE; N68-78W/65-70SW; NO7E/65SE \\
\hline FRATURAS DE CISALHAMENTO DO TIPO 2 & N55-65E/65-75SE \\
\hline FAIHAS NORMAIS & N40-45E/ 80-85SE \\
\hline
\end{tabular}

Tabela 4.1 - Atitudes predominantes de estruturas geológicas

Os planos de acamamento na área dos sistemas de cavernas estudados refletem estruturalmente uma superficie ondulada, com direções predominantes em torno de $\mathrm{N} 35 \mathrm{~W}$ e mergulhos mais freqüentes para NE, de 5 a $10^{\circ}$, localmente atingindo até $30^{\circ}(4.21 \mathrm{G})$. Um outro conjunto planos medidos estão dispersos na direção NE-SW com mergulhos para SE e menos freqüentemente para NW. Os mergulhos de camadas para vários quadrantes sugerem ondulações dômicas desta superficie associadas a mesodobras abertas e dobras parasíticas. 
A Orientação de condutos

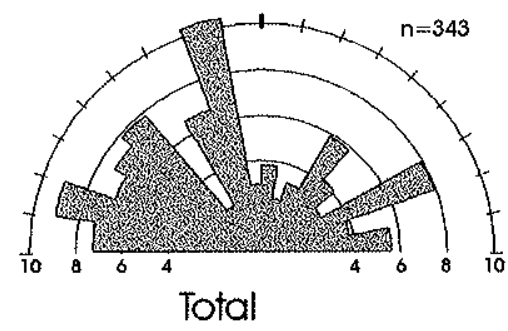

Orientação de condutos

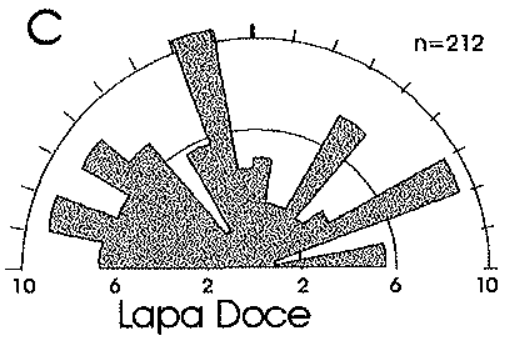

E Orientação de condutos

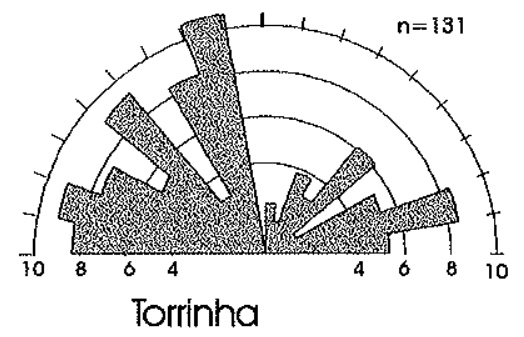

Comprimento de condutos

B
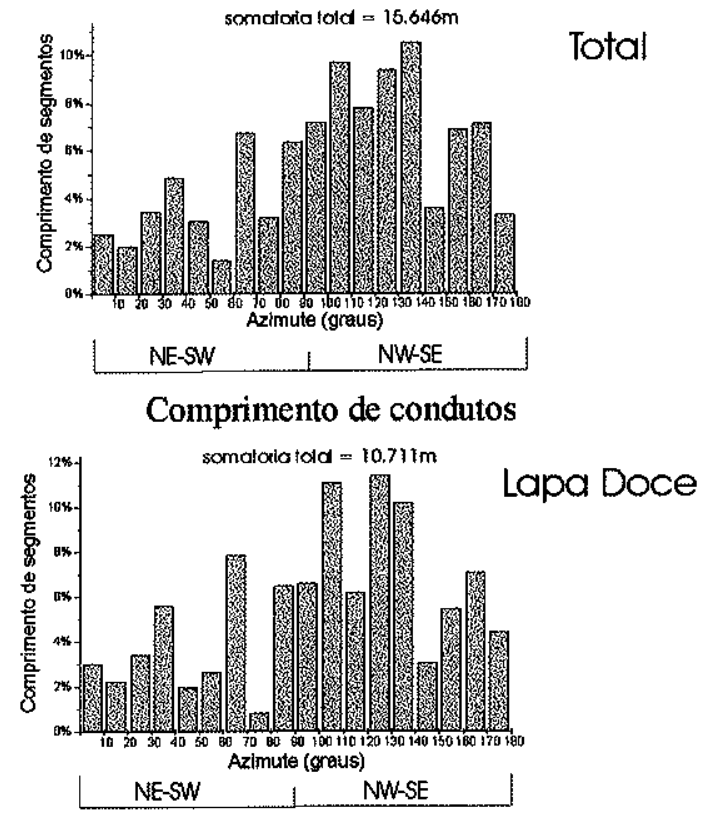

$\mathrm{F}$
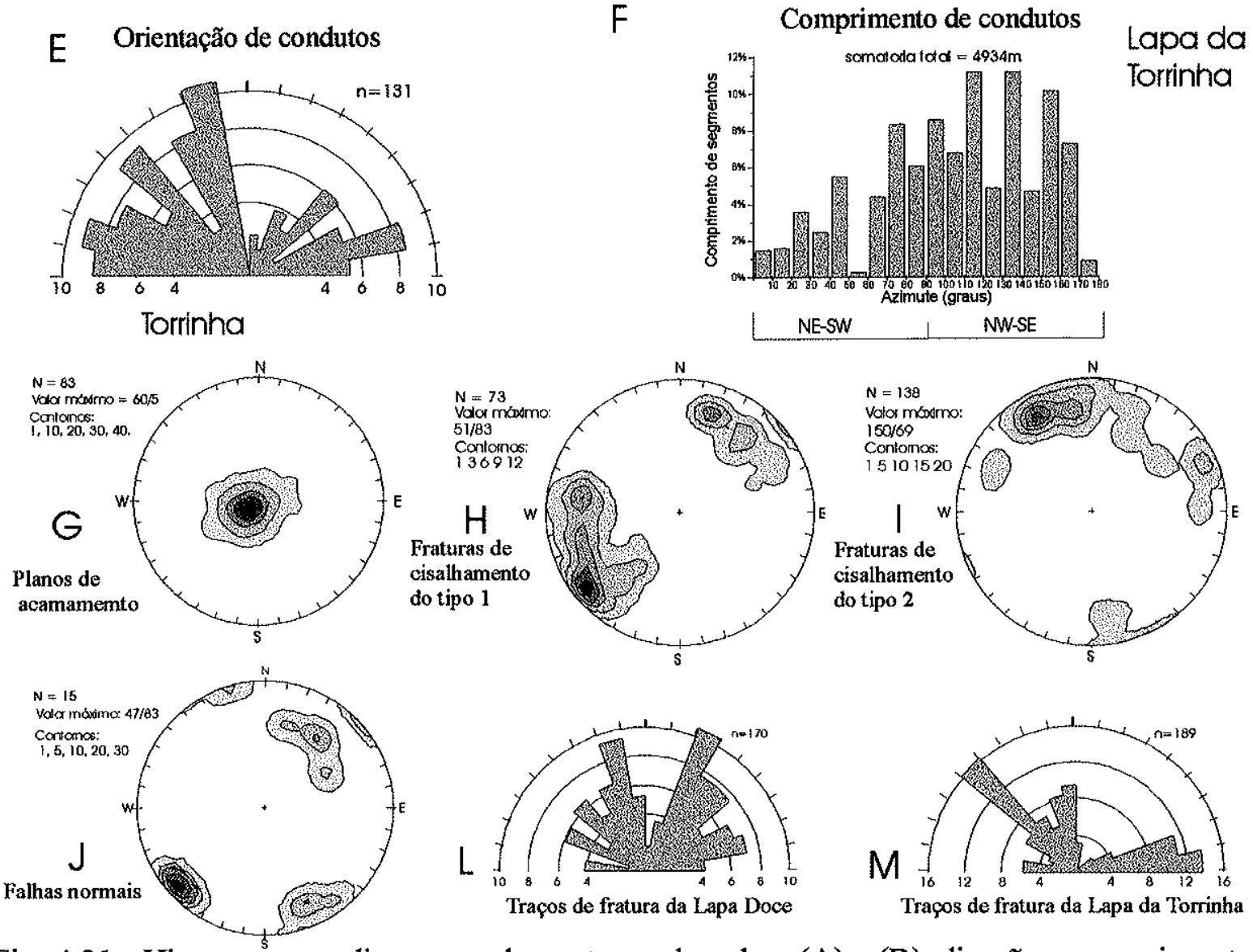

Fig. 4.21 - Histogramas e diagramas de contorno de polos: (A) e (B), direção e comprimento do total de condutos; (C) e (D), direção e comprimento de condutos da Lapa Doce; (E) e (F), direção e comprimento de condutos da Lapa da Torrinha; $(\mathrm{G}),(\mathrm{H}),(\mathrm{I})$ e (J), respectivamente contorno de polos de planos de acamamento, fraturas de cisalhamento do tipo 1, fraturas de cisalhamento do tipo 2, falhas normais; (L) e (M) respectivamente traços de fraturas nos sistemas Lapa Doce e Lapa da Torrinha. 
Interpreta-se a predominância de mergulhos para NE, como sendo consequêencia da localização dos sistemas de cavernas no flanco SW da sinforma regional descrita por Misi (1979) e Dandefer-Filho (1990). É importante comentar que o intervalo de direção predominante dos segmentos de condutos (N10-20W) está próximo a direção preferencial dos planos de acamamento medidos (N30W).

Foram medidos dois tipos de fraturas de cisalhamento. As fraturas de cisalhamento do tipo 1, geralmente sigmoidais, possuem espessura irregular centimétrica a decimétrica, e são preenchidas por calcita com textura homogenea e sílex. Elas ocorrem em locais restritos nas cavernas, como no conduto da Pedra Furada, sob atitudes que variam entre N43-57W/85 a $87^{\circ} \mathrm{NE}, \mathrm{N} 68-78 \mathrm{~W} / 67$ a $70^{\circ} \mathrm{SW}$ e N0-7E/65SE (fig. $4.21 \mathrm{H}$ ). Normalmente são verificados rejeitos de alguns centímetros e com movimentação normal ou reversa associados a rotação de blocos entre as juntas (fig. 4.22). A rotação de blocos está evidenciada localmente por acamamentos com altas inclinações.

As fraturas de cisalhamento do tipo 2 , possuem espessura regular de alguns milimetros e geralmente são preenchidas por calcita e sílex. Seu comprimento varia de centimétrico a decimétrico. Elas ocorrem com pequenos espaçamentos e rejeitos quase sempre normais variando entre 4 e $7 \mathrm{~mm}$, sendo que parte delas não demonstram rejeitos (fig. 4.23). A maior parte destas fraturas possuem atitudes variando entre N55-65W, mergulhando 65 a $75^{\circ}$ para SE (fig. $4.21 \mathrm{I}$ ). Fraturas simples ou sem preenchimento, ocorrem também com a mesma atitude, no entanto são menos comuns.

As falhas são estruturas pouco abundantes nos sistemas de cavernas, sendo mais freqüentes as falhas normais. Estas estruturas podem ter vários metros de comprimento e rejeitos verticais centimétricos, quase sempre com uma componente transcorrente. Localmente foram verificadas estreitas zonas de cisalhamento com movimento combinado normal-transcorrente. A direção geral destas falhas é N40-45E, mergulhando 80 a $85^{\circ}$ para SE (fig. $4.21 \mathrm{~J}$ ).

\section{Tracos de fraturas mapeados}

Os histogramas com medidas de traços de fraturas demonstram intervalos com orientação preferencial diferentes para os sistemas estudados (fig. 4.21L e M). Os traços de fraturas medidos no tetos de condutos foram identificados em vários locais como fraturas escalonadas ou en echelon (fig. 4.5). Estas estruturas compreendem um conjunto com dirę̧ões diferentes em relação as demais fraturas medidas especificamente nas paredes dos condutos (Fig. $4.21 \mathrm{H} \mathrm{e} \mathrm{I}$ ). 


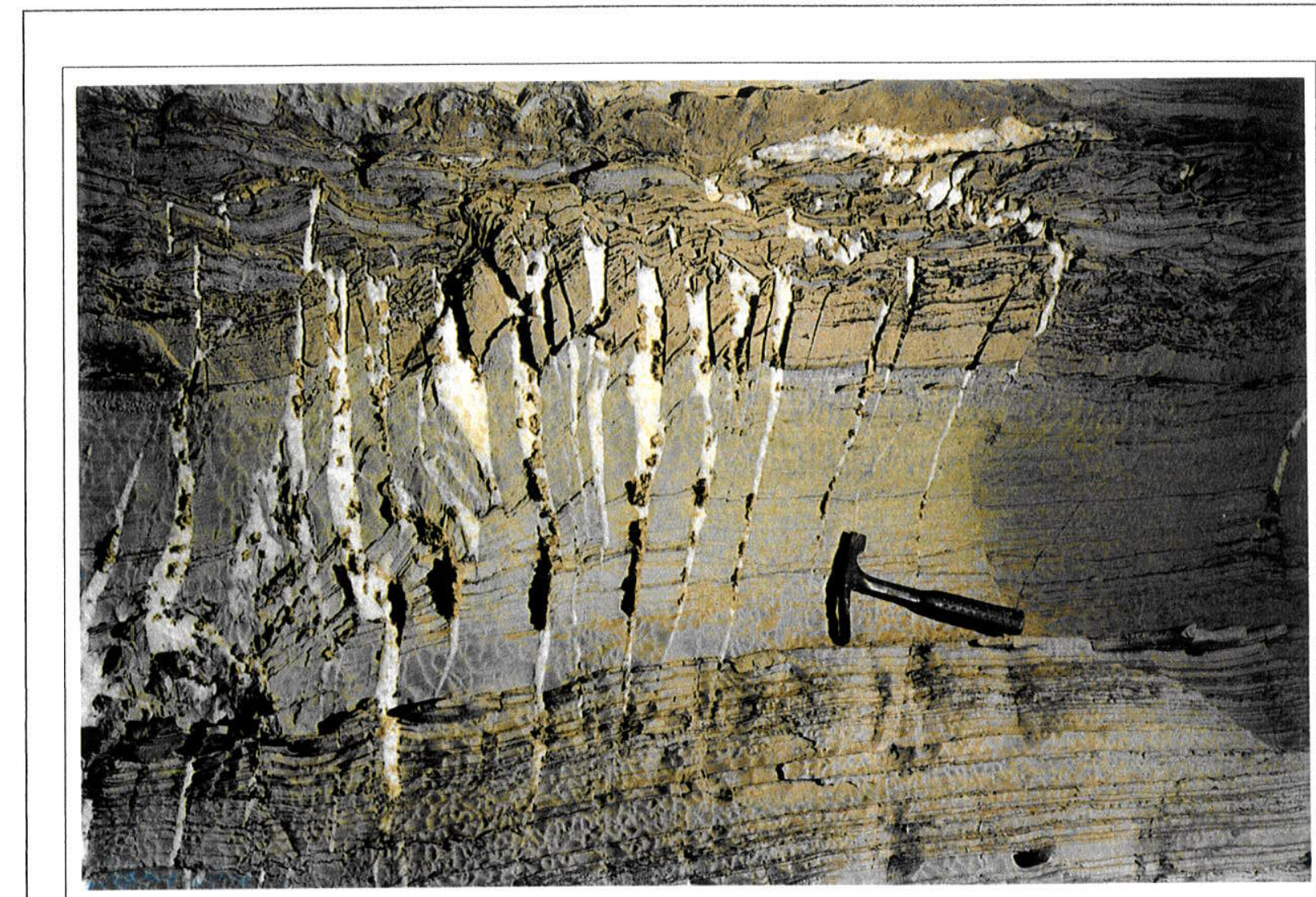

Fig. 4.22 - Fraturas de cisalhamento do tipo 1. Foto do autor.

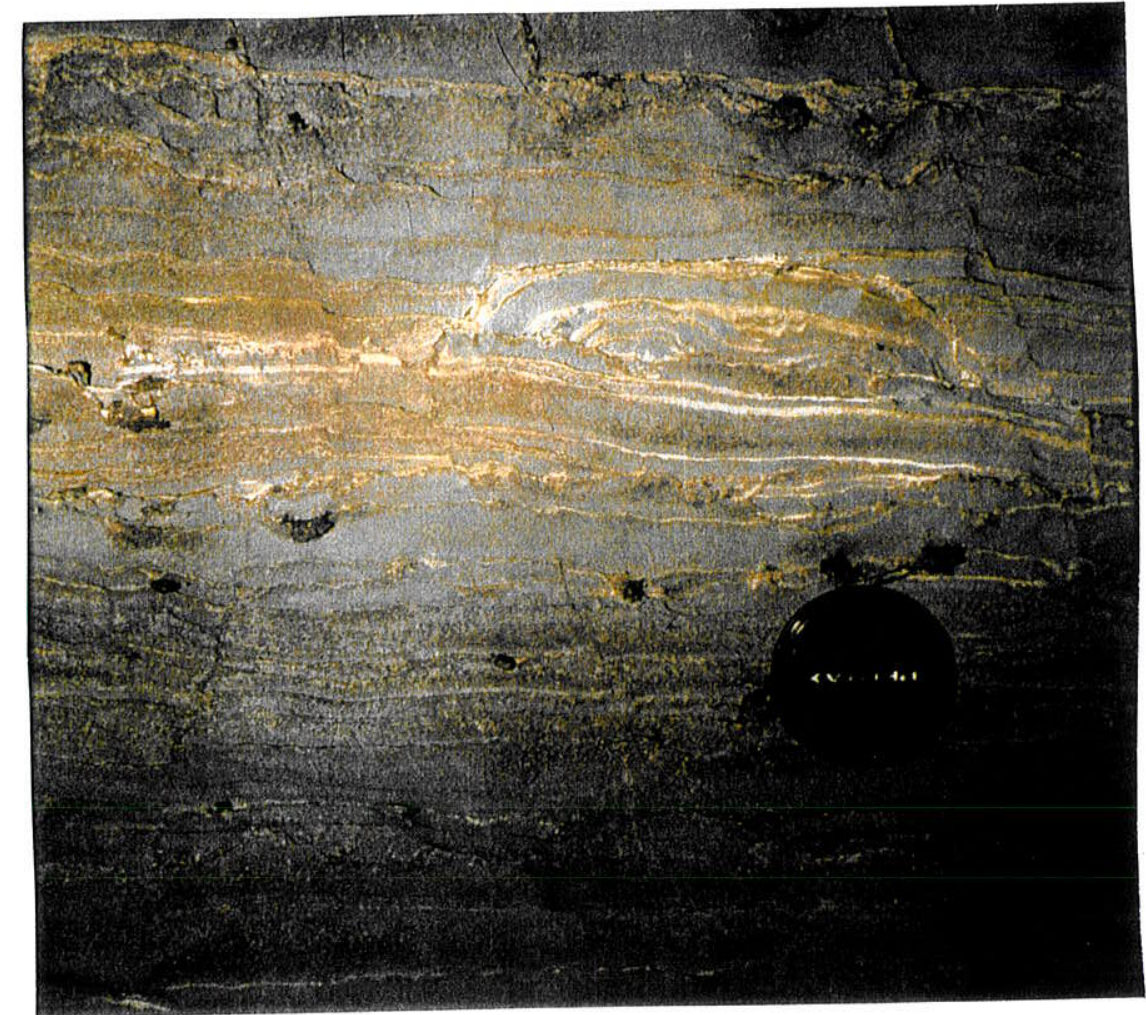

Fig. 4.23 - Fraturas de cisalhamento do tipo 2. Foto do autor. 
Os intervalos N20-30E e N10-20W (fig. 4.21L), correspondem às maiores concentrações de traços de fraturas medidos no Sistema Lapa Doce. No Sistema Lapa da Torrinha, por outro lado, as maiores concentrações estão nos intervalos N40-50W, N70-90E e em menor proporção, $\mathrm{N}$ a N20W (fig. $4.21 \mathrm{M}$ ).

As fraturas possuem distribuição irregular nos sistemas de cavernas, pois elas ocorrem preferencialmente em alguns locais e em outros estão quase ausentes. A comparação entre a direção de segmentos de passagens de cavernas e a direção de traços de fraturas indicou o condicionamento estrutural de setores onde as fraturas são muito freqüentes. Os histogramas de direção e comprimento, e o teste de correlação K-S com intervalos de classe de $10^{\circ} \mathrm{Az}$ apontam os setores 1 (Pedra Furada) e 6 (Neguinho), como condicionados por fraturas. Em alguns setores o condicionamento foi descartado devido a ausência de estruturas que justificassem esta correlação, fato verificado por exemplo nos setores 2,3 e 5 .

O total de dados referentes a direção de segmentos de condutos comparados com os traços de fraturas medidos nos sistemas de cavernas não apresentaram correlação, de acordo com o teste K-S. Isto sugere que o condicionamento estrutural de passagens de cavernas por fraturas ocorre localmente na escala dos setores mapeados

\section{Paleorrotas de fluxo}

Os sentidos das paleorrotas do fluxo de água medidos através de marcas de correntes indicam que o fluxo geral nos sistemas orientava-se de NW para SE, tanto no Sistema Lapa Doce quanto no Sistema Lapa da Torrinha (fig. 4.24). As maiores ramificações de condutos iniciam-se nas galerias principais o que caracteriza o padrão morfológico distributário em ambos sistemas de cavernas. As paleorrotas de fluxo identificadas neste trabalho são condizentes com o mapa de paleofluxo apresentado por Ferrari (1990). 


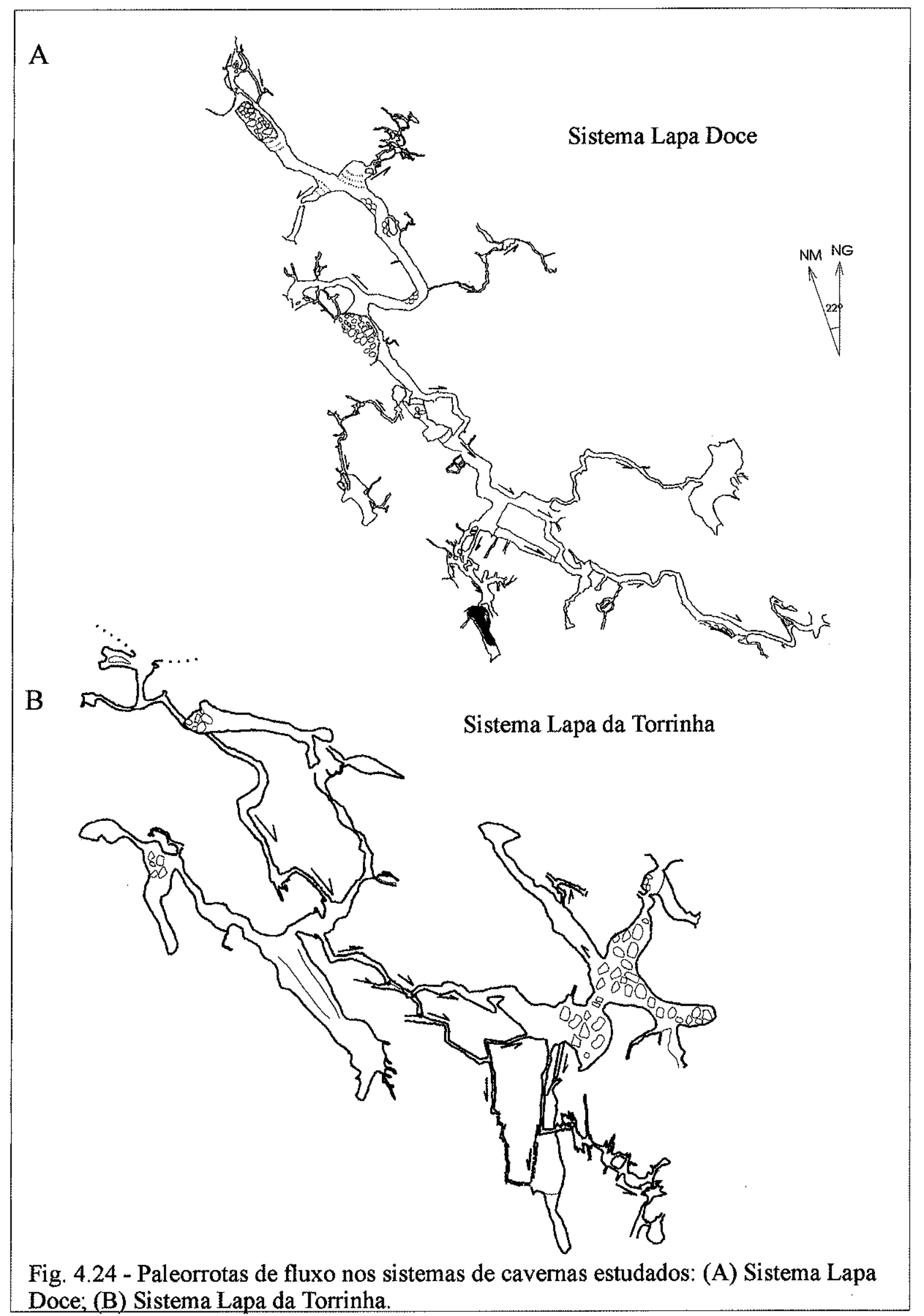


A evolução dos sistemas de cavernas a ser discutida no presente trabalho baseia-se principalmente nos dados morfológicos, geológicos e hidrológicos, que possibilitam comparações entre os tipos morfológicos mapeados em subsuperficie.

A correlação entre diversas feições morfológicas de superficie e subsuperficie, foram obtidas diretamente a partir do mapa de fenômenos cársticos e indiretamente a partir das análises morfométricas e testes estatísticos.

5.1 - Condicionamento hidrológico e geológico do desenvolvimento dos condutos

O quadro de pré-iniciação de condutos é de uma sinforma carbonática circundada por metarenitos. As rochas carbonáticas são finamente laminadas, sendo caracterizadas por planos de acamamento bem desenvolvidos.

Os planos de acamamento possuem direção geral N30W e mergulhos de 5 a $10^{\circ}$ para NE. Estas estruturas são concebidas como as superficies mais favoráveis para percolação de água na rocha, devido a sua freqüente distribuição e continuidade observadas ao longo dos trechos de galerias. Por isso, estas estruturas correspondem aos segmentos mais susceptiveis a iniciação de condutos.

A direção geral dos condutos N20-30W por conseguinte é aproximadamente concordante com a direção das camadas. Localmente, os condutos nos setores são oblíquos a direção dos planos de acamamento devido a sua sinuosidade.

Os segmentos estruturais representados pelas fraturas e pela intercessão entre os planos de acamamento-fraturas ou acamamentos-falhas são zonas altamente permeáveis e assim muito favoráveis a iniciação de condutos (Jameson, 1985). As fraturas estão distribuídas de forma heterogênea ao longo dos sistemas de cavernas. Alguns setores possuem baixa densidade de fraturas mapeadas, a exemplo dos setores $2,3,4$ e 5 (Anexos 3, 4, 5 e 6) e outros possuem grande densidade de fraturas, como os setores 1, 6, 7, 8 e 9 (Anexos 2, 7, 8, 9, 10).

A heterogeneidade da distribuição destas estruturas nos sistemas de cavernas é um dos principais fatores considerados para justificar o condicionamento por fraturas apenas nos setores 
1 e 6 na Lapa Doce e, em partes restritas dos demais setores, de acordo com a disposição dos traços de fraturas mapeados, pela comparação entre histogramas e principalmente com base nos testes estatísticos.

A presença de fraturas e falhas induz a abertura de canyons na base das galerias com piso rochosos e formação de cúpulas de corrosão no teto. Além disso, consiste num importante meio de iniciação lateral de condutos, mais claramente de condutos de pequeno porte, com menos de $1 \mathrm{~m}$ de largura

Os sistemas Lapa Doce e Lapa da Torrinha tiveram sua iniciação associada a injeção mista com importante fração alogênica em relação a autogênica. Este fato é evidenciado pela superficie carbonática rebaixada em relação aos metarenitos (fig. 2.2) e pela geometria dos vales cársticos e sua continuidade sobre as rochas não-carbonáticas (Anexo 1).

Considera-se, no quadro de iniciação destes sistemas, o domínio do gradiente hidráulico no sentido geral SE, com base na orientação principal dos condutos (fig. 2.3) e pela configuração dos vales cársticos convergindo para o Rio Santo Antônio, que por sua vez, consiste no nível de base da área. As rotas de fluxo sugeridas pelos vales e cavernas constituem-se no caminho mais curto, desde o seu início até o referido rio. Deve-se acrescentar que o sentido de fluxo piezométrico tende a acompanhar aproximadamente a direção dos vales e cavernas (fig. 2.5).

A instalação de pontos de absorção de recargas alogênicas ou de paleosumidouros, ocorreu inicialmente em função do contato geológico entre rochas carbonáticas e nãocarbonáticas a NW dos sistemas estudados.

Acredita-se que o paleosumidouro do Riacho Água de Rega tenha sido o principal meio de recarga durante a evolução destes sistemas. Este fator pode ser evidenciado pela continuidade topográfica do vale do Riacho Água de Rega em subsuperficie com o conduto principal do Sistema Lapa Doce.

O Sistema Lapa da Torrinha está provavelmente associado a mesma rota de fluxo que formou o Sistema Lapa Doce, apesar de não ter sido encontrada uma ligação atual entre os dois sistemas. A entrada principal do Sistema Lapa da Torrinha encontra-se situada no fundo de uma grande depressão cárstica a cerca de aproximadamente $600 \mathrm{~m}$ de uma das entradas do Sistema Lapa Doce. A ligação entre estes sistemas pode ter sido interrompida por colapsos de alguns de seus trechos ou entupimento com detritos. 


\section{2 - A evolução morfológica de condutos}

Os sistemas de cavernas estudados possuem uma evolução multifásica de acordo com a classificação de Ford \& Williams (1989). A história evolutiva da formação dos sistema de cavernas leva em consideração fatores como: diferentes níveis de condutos; truncamento de passagens de cavernas, passagens preenchidas por sedimentos e passagens onde ocorreram a erosão dos sedimentos e modificação da morfologia original das galerias. A ordenação destes fatores no contexto evolutivo dos sistemas é complexa e requer uma série de considerações a respeito dos processos de abertura e preenchimento de condutos, processos esses, nem sempre muito evidentes.

A fase de iniciação de condutos, ou seja, a instalação de proto-condutos, não foi possível de ser identificada, pois não se constatou a presença dos proto-condutos. A não observação destas feições é devida principalmente a modificação dos condutos por sucessivos eventos de ampliação.

A morfologia observada em planta, associada às rotas de paleofluxo, indica que o desenvolvimento de condutos gerou sistemas de cavernas distributários, com fluxo geral para SE. A recarga concentrou-se principalmente nas galerias principais, de onde formaram-se os ramos laterais de condutos e os condutos menores, de acordo com os mapas de paleofluxo (Fig. 4.25).

O sentido de fluxo distributário verificado nestes ramos laterais, predominou ao longo da evolução dos condutos, pois não existem sumidouros de drenagens em superficie que evidenciem o escoamento de água em direção a galeria principal.

A fase de desenvolvimento responsável pela ampliação e formação de condutos com grandes diâmetros foi efetuada em regime de rebaixamento no nível de água. Isto pode ser confirmado através das ramificações de condutos dispostas em diversas alturas e também abaixo das galerias principais.

No vale do Rio Santo Antônio, nível de base das drenagens subterrâneas locais, o processo de rebaixamento do nível de água, da mesma forma, gerou níveis de cavernas atualmente secos e situados acima do nível das surgências, a exemplo de cavernas localizadas nas proximidades da surgência da Pratinha (fig. 2.3). Os níveis das surgências cársticas e, por conseguinte, os das galerias, acompanham geralmente o entalhamento do rio principal, representado pelo Rio Santo Antônio. 
Acredita-se que todos os níveis constituídos de ramificações laterais de condutos, tenham sido iniciados durante algum momento de atividade das galerias principais dos sistemas, inclusive os níveis inferiores de condutos, situados 4 a $6 \mathrm{~m}$ abaixo destas, no caso do Setor 6 (Anexo 7 ).

No setor 9, na Lapa da Torrinha, condutos aproximadamente paralelos as galerias principais foram formados em porções inferiores, seguindo a mesma rota de fluxo. Ambos condutos são truncados por outros mais recentes.

A análise morfológica das passagens de cavernas em seção transversal, é utilizada extensivamente para indicação das feições de iniciação e desenvolvimento dos condutos, nas zonas freáticas e vadosas (Bretz 1942, Bögli 1980, Palmer 1991). Na zona vadosa ou insaturada, os condutos são formados com o preenchimento parcial de água e o fluxo move-se principalmente por gravidade. Devido a estes fatores ele é comparativamente mais veloz e turbulento do que o fluxo na zona freática. Na zona freática ou saturada, os condutos são formados com preenchimento total de água, concentrada ao longo de trajetórias com maior eficiência hidráulica e o fluxo movimenta-se em resposta a combinação da gravidade e pressão hidrostática.

Nos sistemas estudados, os padrões morfológicos de seções transversais podem ser interpretados de acordo com os sucessivos eventos de abertura e preenchimento sedimentar de condutos, seguida da erosão do sedimento e modificação da morfologia de condutos preexistentes (tabela 5.1).

\begin{tabular}{|c|c|c|}
\hline FASES EVOLUTIVAS & PROCESSOS ATUANTES & PRINCIPAIS EVIDÊNCIAS \\
\hline Abertura & $\begin{array}{l}\text { Inicią̧ão e desenvolvimento freático de } \\
\text { condutos }\end{array}$ & $\begin{array}{l}\text { Morfologia elipsoidal predominante nas } \\
\text { galcrias principais e em outros setores das } \\
\text { cavernas (?). }\end{array}$ \\
\hline Ampliação de condutos & $\begin{array}{l}\text { Entallamento normal por evoluçẫo } \\
\text { singenética }\end{array}$ & $\begin{array}{l}\text { Níveis de condutos, registro sedimentar, } \\
\text { caracterizado por fácies depositadas em canal } \\
\text { aberto }\end{array}$ \\
\hline Assorcamento dos condulos & $\begin{array}{l}\text { Preenchimento total ou parcial de condutos, } \\
\text { modificação de condutos preexistentes por } \\
\text { paragênese }\end{array}$ & $\begin{array}{l}\text { Condutos atualmente preenchidos, canais de } \\
\text { teto, conjuntos de pendants e pilares com } \\
\text { aspecto de karrens, condutos com tetos } \\
\text { planos }\end{array}$ \\
\hline Desobstrução dos condutos & $\begin{array}{l}\text { Remoção do preenchimento sedimentar dos } \\
\text { condutos, erosão das passagens de cavernas, } \\
\text { abertura de passagens menores }\end{array}$ & $\begin{array}{l}\text { Canais de erosão do piso constituido por } \\
\text { sedimentos, marcas de sedimentos no teto, } \\
\text { feições de erosão de conchtos como nos tetos } \\
\text { e paredes. }\end{array}$ \\
\hline
\end{tabular}

Tabela 5.1 - Resumo das principais fases evolutivas dos sistemas de condutos estudados 
Os sistemas de cavernas foram integralmente atingidos por uma importante injeção de sedimentos clásticos, que levou ao preenchimento total ou parcial de suas galerias. Vestígios da acumulação de sedimentos, representados por crostas e manchas de sedimentos nas paredes e tetos, são encontrados em trechos onde os sedimentos preencheram anteriormente as galerias. A deposição de sedimentos, é desse modo, muito importante para análise morfológica das seções transversais de condutos, pois a sua acumulação pode induzir a formação de novos condutos ou modificar a morfologia de condutos preexistentes.

\section{Fase de abertura e ampliação de condutos}

A principal questão que envolve a abertura, ampliação e preenchimento de condutos é se os sedimentos foram depositados concomitantemente com a abertura dos condutos, num único evento, ou se os mesmos foram depositados num evento posterior, após a abertura e entalhamento dos condutos (fig. 5.1).

Na primeira hipótese formariam-se condutos paragenéticos de acordo com a definição de Renault (1968) e Lauritzen \& Lauritsen (1995), onde a acumulação de sedimentos teria protegido a base das passagens contra a dissolução. Nestes casos as paredes e o teto são dissolvidas por erosão ascendente. A morfologia dos condutos paragenéticos é caracterizada por tubos e condutos elípticos na base, que evoluem para cima como canyons. No topo dos canyons é comum a presença de canais de teto e cúpulas de corrosão (fig 5.1a).

A outra hipótese refere-se a classificação mais tradicional de seções transversais com morfologia freática inicial e vadosa posterior, que leva em consideração a transição de passagens superiores em tubos freáticos e formas afins, para canyons vadosos entalhados em porções inferiores dos condutos freáticos (fig. 5.1b). Esta transição, define a posição do lençol freático e a sua tendência de rebaixamento, acompanhando geralmente a erosão na base dos condutos. Os condutos formados nestas condições são definidos como singenéticos por Renault (1968).

Nos setores mapeados, onde as passagens de condutos não possuem alterações por processos de incasão, as seções transversais apresentam morfologia em canyon e elipsoidal (fig.4.20a). A morfologia individualmente não é um parâmetro conclusivo para determinar se houve abertura paragenética ou singenética de condutos. A formulação de critérios para identificação do processo responsável por tais feições é necessária, a exemplo da Mammoth Cave System no Kentacky, Estados Unidos (Palmer, 1989) e em cavernas situadas nas área Gunung Mulu e Eldon Hill Quarry, respectivamente na Malásia e na Inglaterra (Farrant, 1995). 


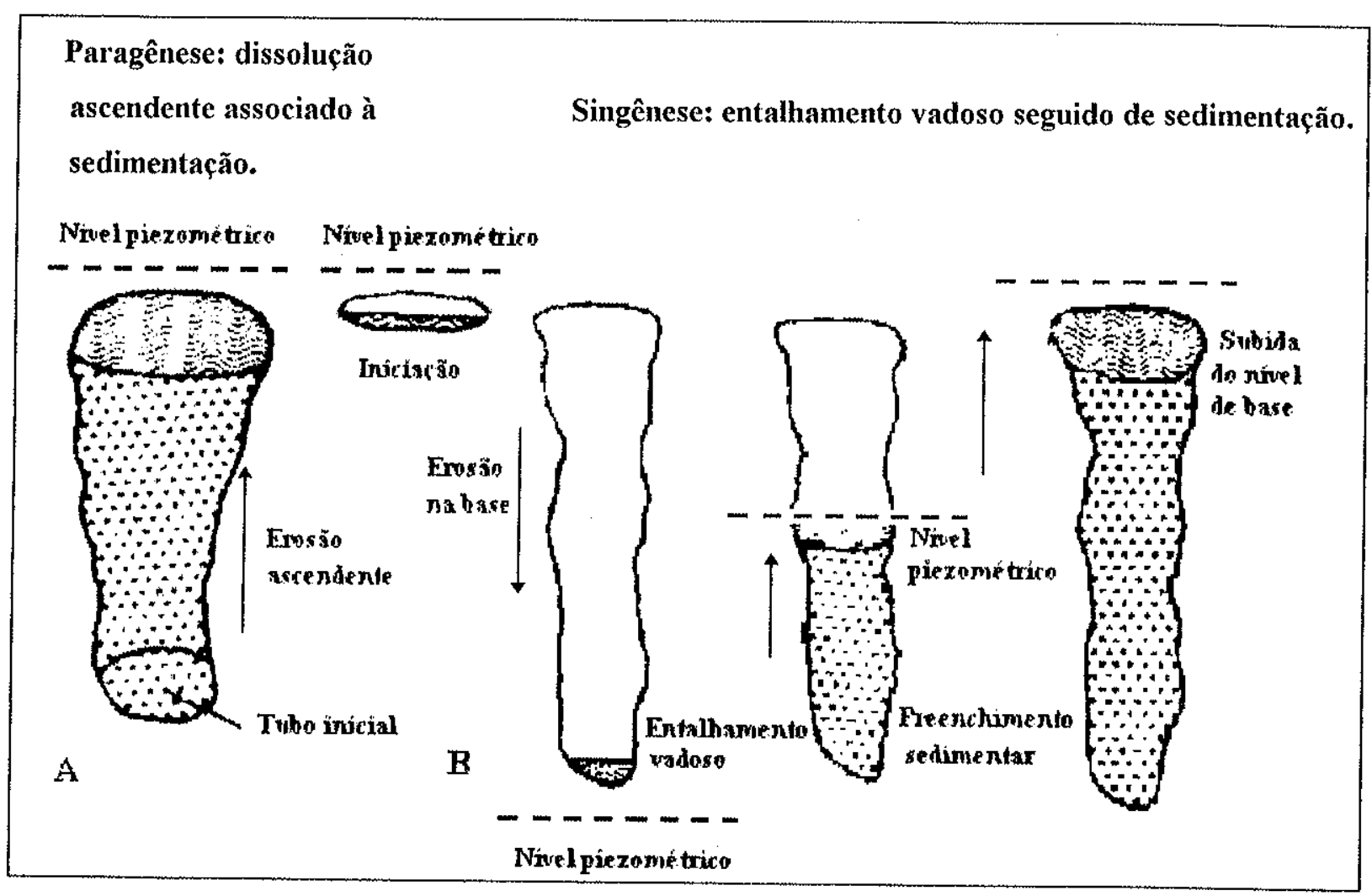

Fig. 5.1 - Ilustração esquemática da evolução de condutos paragenéticos e singenéticos. Modificado de Palmer (1989).

Os condutos em canyon nos sistemas estudados permitem ser interpretados como sendo produtos tanto da singênese como da paragênese. As terminações de topo também não são conclusivas para fundamentar a distinção entre estes processos, pois muitas vezes não é possível distinguir a morfologia de tubos freáticos, que indicariam uma iniciação freática e posterior entalhamento vadoso, de canais de teto ou half tubes, no caso da paragênese.

Mesmo assim, em alguns casos, a morfologia freática singenética é mais evidente, como em condutos do nível inferior da Lapa da Torrinha, setores 7 e 8 (figs. 4.12 e 4.13) e na galeria principal, setores 2 e 4 da Lapa Doce (fig. 4.9). Os canais de teto, quando ocorrem, são mais sinuosos e geralmente não ocupam toda a área do teto e, nos condutos mapeados, estão quase sempre relacionados com tetos planos.

As principais evidências em favor da ampliação singenética de condutos advém do registro sedimentar descrito por Laureano (no prelo). A seqüência sedimentar que preencheu os condutos é constituída por associações de fácies, correspondentes a sistemas deposicionais distintos 
separados por discordâncias erosivas. A associação de fácies na base da sequüência é caracterizada por fácies de canal apresentando estruturas de corte e preenchimento e brechas com fragmentos de espeleotemas. A associação intermediária é formada por ciclos granodecrescentes de areia.

Ambas as associações de fácies referidas foram depositadas sob sistema de fluxo em canal aberto, de forma semelhante ao regime fluvial, sendo necessária assim, a abertura preliminar dos condutos para instalação do rio subterrâneo.

Num caso oposto, em condições paragenéticas, a sedimentação seria contínua e homogênea e estaria caracterizada pela predominância de sedimentos clásticos finos nas frações argila e silte (Renault, 1968; Ford \& Ewers, 1978).

\section{Fase de assoreamento dos condutos}

Posteriormente a fase de iniciação e ampliação, houve o entupimento parcial ou total de condutos, que levou a modificação de sua morfologia por paragênese (tabela 5.1). O sistema tendeu a se adaptar ao assoreamento, através do entalhamento ascendente.

A associação de fácies representativa desta fase, de acordo com Laureano (no prelo), compreende lamas mal selecionadas e brechas de intraclastos (diamictons), correspondentes a injeção de material para o interior dos condutos, com o nível de base alto, permitindo assim a expansão paragenética.

As feições morfológicas referentes a este evento, foram formadas ao longo da interface representada pelo perímetro da passagem e o topo dos sedimentos por erosão ascendente, como também, pela erosão no contato entre o sedimento e as paredes dos condutos. Relacionados a esta fase, ocorrem as seguintes feições: canais de teto (fig. 4.14), pequenos condutos anastomosados de teto, conjuntos de pendants e pilares com aspecto de karren (figs. 4.8 e 4.11 ) e condutos com tetos planos nivelados pelo nível da água (fig. 4.6).

$O$ topo da seqüência sedimentar geralmente é revestido por uma camada, com espessura decimétrica nos condutos menores e, métrica nos condutos maiores, a exemplo da galeria do Salão do Vale (Setor 9, Anexo 10). Estas camadas são constituídas por sedimentos sílticoargilosos, que estavam em contato com o teto em muitos trechos dos condutos menores e condutos principais, de acordo com manchas no teto. Acredita-se que a redução de volume destes sedimentos por ressecamento, tenha rebaixado o topo das camadas por vários centímetros. 


\section{Fase de desobstrução de condutos}

A fase de desobstrução de condutos envolveu a erosão dos sedimentos e a modificação da morfologia relativa as fases anteriores. Parte dos condutos preservam ainda o nivel de preenchimento sedimentar referente a fase de entupimento.

Os canais formados a partir da erosão do piso de sedimentos e as marcas de sedimento no teto são as principais evidências de desobstrução nos condutos atualmente acessíveis. As paredes destes canais constituem quebras de relevo do piso geralmente com vários metros de altura. Em alguns trechos das galerias maiores, este entalhamento chega a ultrapassar $10 \mathrm{~m}$ de altura. São poucos os locais onde a erosão consegue alcançar o piso rochoso, como por exemplo, em alguns trechos dos setores 1, 5 e 6 na Lapa Doce. É difícil estimar precisamente a profundidade do sedimentos, principalmente nas galerias maiores.

As rotas de fluxo durante a desobstrução de condutos correspondem em muitos pontos a desvios de trechos obstruidos da galeria principal, como nos setores 1 e 5 (Anexo 2 e 6). Na maior parte das galerias as rotas seguem aproximadamente a direção do gradiente hidráulico, a exemplo do Setor Caótico (Setor 9, Anexo 10). Em outros locais, a rota é desviada da direção do gradiente hidráulico por condutos controlados por fraturas, como no setor 6 (Anexo 7).

A erosão dos sedimentos é bem exemplificada no Setor 8 (Anexo 9), em junções de condutos com diferentes morfologias (fig. 5.2). A rota de desobstrução neste caso foi estabelecida num conduto orientado aproximadamente na direção da rota de paleofluxo geral do sistema (NWSE) e que trunca um conduto com maior dimensão na direção NE-SW (fig. 4.15). O sedimento é assim removido, ocasionando o entalhamento de canais no piso de sedimento e também a erosão dos tetos. Nos trechos ainda obstruídos ou não atingidos pela erosão, os tetos de condutos são geralmente planos.

A maioria dos condutos transversais aos canais de desobstrução, permaneceram com o mesmo nivel de preenchimento, todavia existem evidências de que o fluxo tenha eventualmente transbordado dos canais, atingindo estes condutos. Nos condutos transversais a galeria principal da Caverna Lapa Doce I (Anexo 3), especificamente no ramo da Lapa do Sol e Setor 3, foram observados espeleotemas erodidos e com marcas de corrente em sua superfície. No Setor 5 (Anexo 6), pequenas marcas de corrente encontram-se sobrepostas a marcas consideravelmente maiores, indicando a invasão do conduto por um fluxo mais veloz e turbulento. 


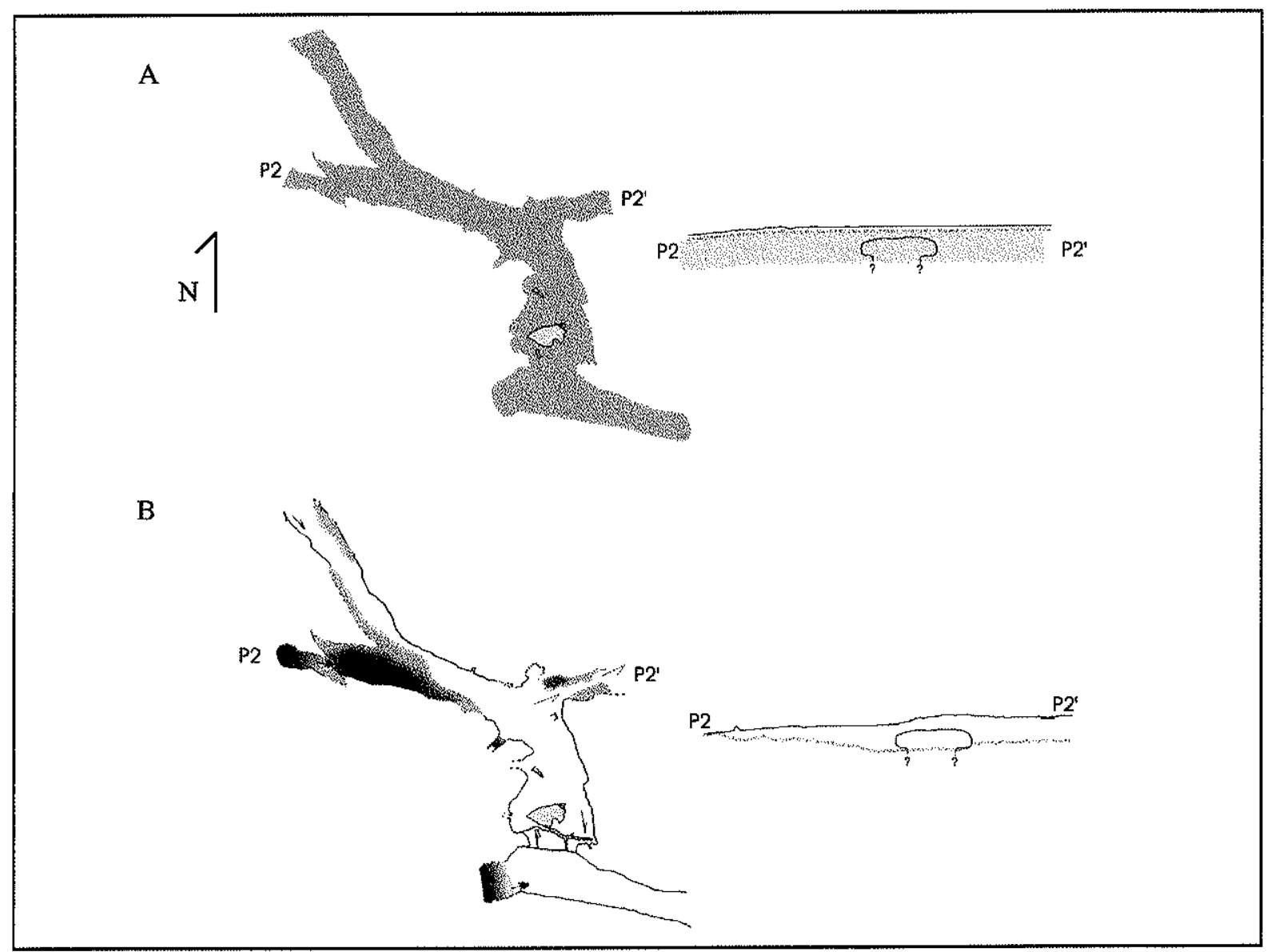

Fig. 5.2 - Quadro evolutivo em planta e perfil em junção de condutos situados no Setor 8, Sistema Lapa da Torrinha: (A) esquema do preenchimento quase total de condutos durante a fase de assoreamento; (B) situação atual após a fase de desobstrução de condutos.

A fase de desobstrução envolveu a formação das seguintes feições morfológicas: canais de erosão do sedimento; entalhamento de canyons na base dos condutos; e erosão das paredes de condutos com a ampliação passagens laterais.

Os canyons entalhados na base dos condutos com pisos rochosos, são caracterizados por seções transversais com patamares de rocha (fig. 4.20a) e desenvolveram-se quando a remoção de sedimentos foi completa. As bordas destes canyons estão situadas aproximadamente na mesma altura do contato sedimento-rocha observados nos setores 5 e 6 (Anexos 6 e 7).

$\mathrm{O}$ entalhamento lateral de condutos indica que a drenagem desobstruindo as passagens erodiu preferencialmente o sedimento e as paredes de um lado da galeria, conservando-os no lado 
oposto. Esta feição é observada principaimente nas galerias maiores dos sistemas, a exemplo do setor 4 (Anexo 5). As marcas de corrente dos setores 4 e 5, sugerem que o fluxo de água era bem mais lento na parte superior do conduto, tornando-se mais rápido e turbulento no sentido da base do conduto.

Nesta fase de erosão dos condutos houve a ampliação de pequenas passagens laterais e formação de outras, principalmente na base das galerias. As seções transversais e perfis longitudinais mostram que parte das paredes de condutos do setor (Anexo 10) foram erodidas deixando eventualmente alguns pilares como testemunhos. Parte do sedimento removido durante esta fase, foi depositado em condutos situados em níveis inferiores, assim como já sugeriu Ferrari (1990).

A erosão dos sedimentos provavelmente instabilizou as paredes e tetos das galerias, desencadeando amplos processos de incasão dos condutos, especialmente naqueles de maior porte. Isto pode ser exemplificado através de condutos menores que truncam a base atual da galeria principal no Salão da Junção (seção c-c', Anexo 10). Com isso, o sedimento que exercia pressão nas paredes e tetos foi erodido, induzindo desabamentos no local. O mesmo processo pode ter atuado também ao longo dos numerosos trechos dos sistemas onde existem grandes empilhamentos de lajes e blocos.

É importante enfatizar que o material proveniente dos processos de incasão estão situados sobre altos níveis de sedimentos, sugerindo que os desabamentos ocorreram principalmente após a fase de preenchimento, concomitantemente a erosão dos sedimentos que preenchiam parte dos condutos.

\section{3 - Correlação entre as feições cársticas superficiais e subterrâneas}

Os principais sistemas de cavernas na área estudada estão posicionados nas proximidades dos vales do Rio Santo Antônio e dos riachos do Água de Rega, das Almas e do Gado. Os padrões morfológicos gerais das cavernas foram influenciados por recargas concentradas de fluxo, injetadas por drenagens superficiais, destacando-se os riachos Água de Rega e das Almas. Isto pode ser caracterizado pela presença de sumidouros ou paleosumidouros associados às rotas de condutos e vales de abatimento em superficie. 
O Rio Santo Antônio percorre o extremo sul do planalto carbonático possuindo um curto percurso no local em relação a área abrangida pelos carbonatos. No entanto, a sua presença é de grande importância para o condicionamento do fluxo subterrâneo nas rochas carbonáticas e para história geomórfica da área. Este rio sofre uma notável inflexão do seu curso de N-S para E-W, após aproximadamente $15 \mathrm{~km}$ de percurso no planalto carbonático. Em seguida, ele sai do planalto, atravessando inclusive as serras areniticas, que são os principais divisores de drenagens na área.

$O$ referido rio e seus afluentes locais formaram vales bem encaixados nas rochas carbonáticas, dissecando o relevo da porção centro-sul da área, tendo visto o rebaixamento da superficie carbonática entre 80 e 150m, em relação a parte norte da área (Fig. 2.2). Com isso, houve também o aumento do desnível da superficie do terreno e, consequentemente, do gradiente hidráulico das drenagens provenientes das serras areníticas, que encontram-se orientadas no sentido do Rio Santo Antônio.

As rotas de fluxo subterrâneo representadas pela direção geral das cavernas e vales, além das linhas de fluxo hipotéticas do mapa potenciométrico (fig. 2.5), consistem aproximadamente na menor distância do trajeto estabelecido entre as serras e o vale do Rio Santo Antônio.

A configuração das litologias carbonáticas e não-carbonáticas, corresponde a outro fator importante no desenvolvimento de drenagens alogênicas na área. As rochas carbonáticas estão distribuídas de acordo como uma faixa triangular com largura de $7 \mathrm{~km}$ a sul e $25 \mathrm{~km}$ a norte, margeada por rochas não-carbonáticas (Anexo 1).

A porção central e sul da área são caracterizadas por uma grande quantidade de depressões fechadas de perfil escarpado, formadas principalmente por colapso do teto de cavernas. A extremidade do vale cego do Riacho Água de Rega ao centro da área, é um trecho com grande concentração destas depressões, devido a presença dos sistemas Lapa Doce e Lapa da Torrinha. As depressões neste local aparentam marcar a continuidade do vale em superficie, mantendo a orientação semelhante do Riacho Água de Rega, que é NW-SE, depois orientando-se na direção E-W. Isto sugere que os vales dos riachos Água de Rega e das Almas foram formados a partir de colapso do teto de condutos, sendo assim, vales de abatimentos (vales cársticos).

Quanto aos vales do Rio Santo Antônio e do Riacho Água de Rega, não existem evidências de que o colapso de cavernas tenha acontecido durante o seu desenvolvimento. Estes 
vales podem ter sido entalhados, até o momento, em condições fluvio-cársticas, ou seja, com fluxo superficial normal sobre um assoalho colmatado por sedimentos e, eventualmente condutos acompanhando o seu percurso em subsuperficie (White, 1988).

\section{Correlação com base em análises morfométricas e dados estatísticos}

Os dois grupos de depressões fechadas possuem características distintas quanto a área superficial e comprimento de perímetro. Estes parâmetros auxiliaram na análise da distribuição destas feições ao longo da área, de modo que, foi possível correlacionar as população de depressões com os locais onde existem maior ocorrências de cavernas e aqueles onde as ocorrências são mais restritas.

A densidade de depressões fechadas com perfil escarpado é quase três vezes maior nas porções central e sul da área. Já a densidade de depressões com perfis suaves é aproximadamente semelhante em toda a superficie carbonática. Isto sugere uma maior atuação de drenagens alogênicas na parte central e sul da área, onde os colapsos de tetos de cavernas formaram depressões com vertentes íngremes em rocha carbonática. Em contrapartida, supõem-se também, uma menor influência dos processos de colapsos de tetos de cavernas na formação das depressões com perfis suaves. Estas últimas compõe quase a totalidade das depressões fechadas na porção norte da área, onde a ocorrências de cavernas é consideravelmente menor.

Na porção central e sul da área, foram comparadas a área superficial e o comprimento médio de perímetro das depressões fechadas. Naquelas com perfil escarpado, os respectivos parâmetros são 53,6 e 40,6\% maiores, do que nos tipos de perfil suave. Os locais apresentando maiores freqüências na distribuição de depressões com perfis escarpados, consistem também de trechos com grande densidade de área de depressão por $\mathrm{Km}^{2}$, depressões com circularidade menor que 0,5 e alta razão de dolinamento.

Com o objetivo de verificar a hipótese de condicionamento de depressões fechadas por estruturas geológicas ou pela presença de condutos, obteve-se valores de correlação através do teste estatístico $\mathrm{K}-\mathrm{S}$ admitindo-se $\alpha=0,05$, entre as orientações do eixo maior de depressões e a orientação de fotolineamentos, fraturas e segmentos de condutos.

A hipótese foi confirmada para os dados da orientação de eixo maior de depressões fechadas e segmentos de condutos, tanto na área dos sistemas Lapa Doce e Lapa da Torrinha, quanto na área dos sistemas loio e Impossíveis (fig. 2.3). Já em relação aos dados de eixo maior de depressões e fotolineamentos, há somente correlação na primeira área referida. 
Portanto, admite-se que as depressões fechadas, especialmente aquelas com perfil escarpado, foram desenvolvidas sob o condicionamento de condutos e localmente de fraturas e falhas. Neste contexto é importante comentar que os condutos a exemplo dos sistemas estudados seguem preferencialmente a direção do gradiente hidráulico e dos planos de acamamento. 


\section{6 - CONCLUSÕES E RECOMENDAÇÕES}

O mapeamento morfológico a partir de fotografias em escala 1:25.000, mostrou-se uma importante ferramenta na descrição de feições cársticas na área. As feições mapeadas constam de numerosas depressões fechadas, vales cársticos, poljes, surgências, vales secos e pontos de absorção do escoamento superficial.

Caracterizou-se a presença de dois grupos de depressões com base no contraste entre suas profundidades e na presença de bordas escarpadas identificadas em fotografia aérea. $O$ grupo morfológico representado por depressões fechadas com perfis escarpados está associado principalmente a processos de colapsos de condutos e remoção direta de material da cobertura detrítica para interior de condutos, formando assim dolinas de colapsos, uvalas e dolinas aluvionares. $O$ grupo representado por depressões com perfis suaves é constituído principalmente a dolinas de subsidência lenta, formadas pela remoção e infiltração de material detrítico da cobertura. Sua morfologia consiste de depressões fechadas mais rasas, caracterizada pela ausência de escarpas e também por mergulhos mais suaves e uniformes.

As análises morfométricas confirmam que os dois grupos de depressões fechadas possuem características distintas quanto a sua distribuição e modo de ocorrência, principalmente por conta da presença de cavernas. A densidade de depressões fechadas com perfil escarpado é quase três vezes maior nas porções central e sul da área onde existem maior incidência de cavernas, enquanto que as depressões de perfil suave apresentam-se mais regularmente distribuídas. As áreas e perímetros são, respectivamente, 53,6 e 40,6\% maiores nos tipos de escarpados, do que nos tipos de perfil suave. Os locais apresentando maiores freqüências na distribuição de depressões com perfis escarpados, consistem também de trechos com grande densidade de área de depressões fechadas por $\mathrm{Km}^{2}$, depressões com circularidade menor que 0,5 e razão de dolinamento mais altas. A dirę̧ão do eixo maior depressões, predominantemente nos intervalos N30W a N30E estão correlacionadas estatisticamente com a direção dos segmentos de condutos e localmente com a direção de fotolineamentos. Os alinhamentos NW-SE e E-W de depressões de perfil escarpado, correspondentes a dolinas de colapso e uvalas na área dos sistemas Lapa Doce e Lapa da Torrinha evidenciam que o vale do Riacho Água de Rega foi formado a partir do colapso de condutos.

O padrão morfológico planimétrico geral para os condutos dos sistemas Lapa Doce e Lapa da Torrinha é distributário, caracterizado por amplas galerias, com ramificações em alça, condutos em rede, condutos entrelaçados e salões de abatimentos. Os principais tipos de seções transversais mapeados possuem morfologia em canyon, elipsoidal, retangular e abatimentos, considerando-se a forma da parede e a relação altura $\mathrm{x}$ largura. $\mathrm{O}$ topo das seções pode ser plano, 
geralmente revestido por sílex; côncavo; triangular, associado a presença de cúpulas de corrosão controladas por fraturas; e semi-elípticos a semi-retangulares.

A hipótese de condicionamento dos condutos por estruturas geológicas foi corroborada através da comparação da direção dos segmentos das cavernas e dos traços de fraturas, que ocorrem preferencialmente nos intervalos N10-20W, N50-60W, N70-80W e N60-70E no Sistema Lapa Doce e N10-20W, N40-50W e N70-90W no Sistema Lapa da Torrinha. A correlação foi estabelecida através de testes estatísticos. De modo geral, os sistemas acompanham a direção dos planos de acamamento e a direção inferida do gradiente hidráulico, sendo localmente condicionado por fraturas.

Sugere-se uma evolução multifásica com base na análise morfológica dos condutos e do pacote de sedimentos clásticos. A evolução é descrita em quatro fases: abertura, ampliação, assoreamento e desobstrução de condutos. A morfologia de condutos individualmente não é considerado um parâmetro conclusivo para caracterização das fases de abertura e ampliação de condutos, pois os sucessivos processos de assoreamento e erosão de sedimentos foram bastante influentes na modificação da morfologia original. Portanto, para melhor definição do quadro de evolução dos condutos a morfologia foi associada à fácies sedimentares descritas por Laureano (no prelo).

Em relação à história evolutiva da abertura de condutos, os sistemas Lapa Doce e Lapa da Torrinha tiveram sua iniciação associada a injeção mista com importante fração alogênica em relação a autogênica, evidenciada pelo rebaixamento da superficie carbonática em relação às rochas não-carbonáticas e pela geometria dos vales cársticos. Infere-se na fase de abertura que a morfologia elipsoidal predominante nas galerias principais e em outros setores dos sistemas sejam testemunhos da iniciação e desenvolvimento freáticos de condutos. A fase de ampliação consiste no entalhamento normal de condutos por singênese, com base no nível dos condutos e registro sedimentar de fácies de canal aberto. A fase de assoreamento é caracterizada por um preenchimento sedimentar que chegou a alcançar o teto dos condutos e modificação por paragênese, representada por feições como: canais de teto, conjunto de pendants e pilares com aspecto de karren. A fase de desobstrução dos condutos, evidenciada por marcas de sedimento e canais de desobstrução envolveu a remoção do preenchimento sedimentar, erosão e abertura de novas passagens.

Para melhor definição dos eventos relacionados a abertura e preenchimento de condutos, sugere-se um estudo magneto-estratigráfico da seqüência sedimentar clástica, assim como, um estudo geocronológico em crostas de calcita secundária.

Este trabalho está concentrado somente numa pequena fração do total de condutos existentes na área. Recomenda-se que seja dada continuidade ao estudo geológico dos demais sistemas na região, com o objetivo de refinar o modelo espeleogenético da região. 
Assaad, F.A. \& Jordan, H. (1994) - Karst terranes and environmental aspects. Environmental Geology, 23: 228-237.

Auler, A. \& Farrant, A.R. (1996) - A brief introduction to karst and caves in Brazil. Proceedings of University Bristol Speleological Society, 20 (3): 187-200.

Bahia. Secretaria da Indústria, Comércio e Turismo. Superintendência de Geologia e Recursos Minerais. (1993) - Projeto grutas de Iraquara e seu contexto geológico. (Escala 1: 60.000).

Bogli, A. (1980) - Karst hydrology and physical speleology. Berlin. Spring-Verlag.

Bondesan, A.; Meneghel, M.; Sauro, U. (1992) - Morphometric analysis of dolines. International Journal of Speleology, 21(1/4): 1-55

Brazão, J.E.M. \& Araújo, A.P. (1981) - Vegetação: as regiões fitoecológicas, sua natureza e seus recursos econômicos; estudo fitogeográfico. Brasil. Ministério das Minas e Energia. Secretaria Geral, Rio de Janeiro. Projeto Radambrasil. Folha SD.24 Salvador. pp.405-464

Becker, B.F. \& Wilson, W.L. (1987) - Karst hydrogeology: Engineering and environmental applications. Netherlands. Balkena Publishers. 467p.

Bretz, J.H. (1942) - Vadose and phreatic features of limestones caverns. Journal of Geology 50: 675-811.

Cheema, T.J. \& Islan, M.R. (1994) - Comparison of cave passageways with fracture traces and joints in the black hills region of South Dakota. The National Speleological Society Bulletin 56: $96-103$.

Conover, W.S. (1980) - Pratical nomparametric statistics. $2^{\text {a }}$ ed. New York. Jonh Wiley. 493p.

Courbon, P.; Chabert, C.; Bosted, P. \& Lindsley, K.(1989) - Atlas of the great caves of the world. St. Louis. Cave Books. 369 p.

Cristofoletti, A. (1980) - Geomorfologia. $2^{\text {a }}$ edição. São Paulo. Edgard Blücher. 188p.

Curl, R.L. (1974) - Deducing flow velocity in cave conduits from scallops. The National Speleological Society Bulletin, 36(2): 1-5.

Dandefer-Filho, A. (1990) - Análise estrutural descritiva e cinemática do Supergrupo Espinhaço, na região da Chapada Diamantina, BA. Dissertação de Mestrado. Escola de Minas da Universidade Federal de Ouro Preto. 
Day, M. (1976) - The morphology and hydrology of some jamaica karst depressions. Earth Surface Processes 1(2): 111-129.

Deike, G. H. (1989) - Fracture controls on conduit development. In: White, W.B. \& White, E.L. (eds.), Karst Hydrogeology: concepts from Mammoth Cave. New York, Van Nostrand Reinhold. 259-291.

Dominguez, J.M.L. (1996) - As coberturas plataformais do Proterozóico Médio e Superior. In: Barbosa, J.S.F. \& Dominguez, J.M.L. (1996). Mapa geológico do Estado da Bahia - Texto explicativo. Superintendência de Geologia e Recursos Minerais. 400p. 105-142.

Farrant, A.R. (1995) - Long-term quaternary chronology from cave deposits. Ph.D. Thesis. University of Bristol. 254p.

Ferrari, J.A. (1990) - Interpretação de feições cársticas na região de Iraquara - Bahia. Dissertação de Mestrado. Departamento de Geografia da Universidade Federal da Bahia.

Ferrari, J.A.; Hiruma, S.T; Antonietti, E. \& Karmann, I. (1997) - Geoprocessamento aplicado a caracterização de terrenos cársticos - Núcleo Cablocos (PETAR). Boletim de Resumos Expandidos do Simpósio de Quantificacão em Geociências, 7.

Ford, D. C. \& Ewers, R.O. (1978) - The development of limestone cave systems in the dimensions of length and depth. Canadian Journal Earth Science 15: 1783-1798.

Ford, D. C. \& Williamn, P.W. (1989) - Karst geomorphology and hydrology. London. Unwin Hyman.

Gams, I. (1978) - The polje: The problem of definition with special regard to the Dinaric Karst. . Zeitschrift für Geomorphologie, 22(2): 170-184.

Gonsalves, R.N. \& Pereira, R.F. (1981) - Climatologia. Brasil. Ministério das Minas e Energia. Secretaria Geral. Rio de Janeiro. Projeto Radambrasil. Folha SD.24 Salvador.

Goodchild, M.F. \& Ford, D.C. (1971) - Analysis of scallops patterns by simulation under controlled conditions. Journal of Geology, 79: 52-62.

Guerra, A. M. (1986) - Processos de carstificacão e hidrogeologia do Grupo Bambui na região de Irecê-Bahia. Tese de Doutoramento. Instituto de Geociências da Universidade de SãoPaulo. Hancock, P.L. (1985) - Brittle microtectonics: principles and practice. Journal of Structural Geology, 7: 437-457.

Inda, H.A.V. \& Barbosa, J.F. (1978) - Mapa Geológico do Estado da Bahia 1: 1.000.000. Projeto Radambrasil (DNPM/MME) 
Jameson, R.A. (1985) - Structural segments and the analysis of flow paths in the Nort Canyon of Snedegar Cave, Friars Hole Cave System. Thesis of West Virginia University. Jennings, J. N. (1985) - Karst Geomorphology. Glasgow. Basil Blackwell.

Karmann, 1. (1994) - Evolução e dinâmica atual do sistema cárstico do alto vale do rio Rieira de Iguape, sudeste do estado de São Paulo. Tese de Doutoramento. Instituto de Geociências da Universidade de São Paulo.

Karmann, 1. \& Sánchez, L.E. (1986) - Speleological Provinces in Brazil. Anales do Congreso Internacional de Espeleologia, 9(1): 151-153 Barcelona.

Kemmerly, P.R. (1976) - Definitive doline characteristics in the Clarksville quadrangle, Tennessee Bulletin of Geological Society of America, 87: 42-46.

King, L.C. (1956) - A geomorfologia do Brasil Oriental. Revista Brasileira de Geologia, 18(2)

Laureano, F. (no prelo) - $\mathrm{O}$ registro sedimentar clástico dos sistemas de cavernas Lapa Doce e Torrinha, Município de Iraquara, Chapada Diamantina, BA. Dissertação de Mestrado em andamento. Instituto de Geociências da Universidade de São Paulo.

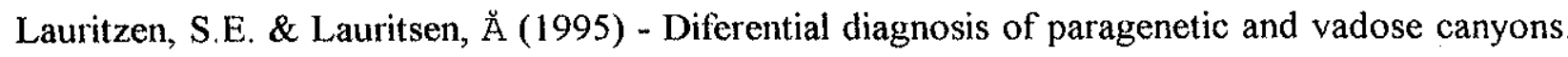
Caves and karst science, 21(2): 55-59.

Martim, P.; Chrysostono, R.S. \& Rodrigues, R.(1989) - Cadastro nacional de cavidades naturais. Índice de dados sobre as cavernas do Brasil. São Paulo. Sociedade Brasileira de Espeleologia. 222 p.

Milanovic, P.T. (1981) - Karst hydrogeology. Littleton. Water Resources Publication. 434p.

Misi, A. (1979) - O Grupo Bambuí no Estado da Bahia. In: Inda, H.V. Geologia e recursos minerais do Estado da Bahia Salvador. SME/CPRM. V. 1: 119-154.

Misi, A. \& Silva, M.G. (1996) - Chapada Diamantina Oriental: Geologia e depósitos minerais. Superintendência de Geologia e Recursos Minerais - Série Roteiros geológicos. Salvador. $194 p$.

Negrão, F. I. (1987) - Caracterização hidrogeoquímica e vulnerabilidade do sistema cárstico da regiao de Irecê - Bahia. Instituto de Geociências da Universidade de São Paulo.

Nunes, B.T.A.; Ramos, V.L.S. \& Dillinger, A.M.S. (1981) - Geomorfologia. In: Projeto Radambrasil. Folha SD 24 (Salvador). Ministério das Minas e Energia. Secretaria Geral. Rio de Janeiro. 
Palmer, A. N. (1984) - Geomorphic interpretation of karst features. In: Lafleur, R.G. Groundwater as a geomorphic agent. Boston, Allen \& Unwin. 381p. 173-209.

Palmer, A.N. (1989) - Stratigraphic and structural control of cave development and groundwater flow in the Mammoth cave region. In: White, W.B. \& White, E.L. Karst hydrogeology: concepts of Mammoth Cave area. New York. Van Nostrand Reinhold. p. 293-316.

Palmer, A. N. (1991) - Origin and morphology of limestone caves. Geological Society of America Bulletin 103: 1-21.

Palmquist, R. (1979) - Geologic controls on doline characteristics in mantled karst. Zeitschrift für Geomorphologie, Supplement Band, 32: 90-106.

Panchout, P.Y. \& Panchout, J.F. (1995) - Brasil - Aventures spéléo sous les tropiques. Le Havre. $172 \mathrm{p}$.

Parizek, R.R. (1976) - On the nature and significance of fracture traces and lineaments in carbonate and other terranes. In: Vevjevich, V. (ed), Karst hydrology and water resources. Vol. 1: Karst hydrology. Colorado. Water Resources Publications. 439p. 47-108.

Pedreira-da-Silva, A.J. (1994) - O Supergrupo Espinhaço na Chapada Diamantina Centro Oriental, Bahia: Sedimentologia, estratigrafia e tectônica. Tese de Doutoramento. Instituto de Geociências da Universidade de São Paulo.

Pereira, R.G.F.A. (1998) - Caracterização geomorfológica e geoespeleológica do carste da bacia do rio Una, borda leste da Chapada Diamantina (Município de Itaetê, Estado da Bahia). Dissertação de Mestrado. Instituto de Geociências da Universidade de São Paulo. 95p.

Quilan, J.F. \& Ewers, R.O. (1981) - Hydrogrology of the Mammoth Cave Region, Kentacky. Field Trip, Geological Society of America, 8: 457-506.

Renault, P. (1968) - Contribution a l'etude des actions mécaniques et sédimentologiques dans la spéléogenèse. Annales de Spéléologie, 23(3): 575-593.

Rubbioli, E.L. (1995) - Iraquara - um novo paraíso espeleológico. O Carste 7(3): 4-10.

Sauro, P.U. (1991) - A polygonal karst in Alte Murge (Puglia, Southern Italy). Zeitschrift furr Geomorphologie, 35(2): 207-223.

Silva, G.B.; Santos, J.H.G. \& Correa, P.R.S. (1981) - Pedologia: Levantamento exploratório de solos. In: Projeto Radambrasil, Folha SD 24 (Salvador). Ministério das Minas e Energia. Secretaria Geral. Rio de Janeiro. 
Slabe, T. (1995) - Cave Rocky Relief and its Speleogenetical Significance. Znanstvenoreziskovaln Center Sazu, Ljubljana, 128p.

Soriano, M.A. \& Simón, J.L. (1995) - Alluvial dolines in the central Ebro basin, Spain: a spatial and developmental hazard analysis. Geomorphology, 11: 295-309.

Souza, S.L.; Brito, P.C.R. \& Silva, R.W.S. (1993) - Estratigrafia, sedimentologia e recursos minerais da Formação Salitre na Bacia do Irecê, Bahia. Série Arquivos Abertos, 2. 34p. Companhia Baiana de Pesquisa Mineral, Salvador.

Terlau, C.A. \& Day, M.J. (1997) - A comparison of the orientation of cave passages and surface tributary valleys in the karst of southwestern Wisconsin, U.S.A. Proceedings of the $12^{\text {th }}$ International Congress of Speleology, 1: 133-136. Switzerland.

Tricart, J. \& Silva, T.C. (1968) - Estudos de geomorfologia da Bahia e de Sergipe. Fundação para o Desenvolvimento da Ciência na Bahia e Imprensa Oficial da Bahia. Salvador. 167p.

White, W. B. (1988) - Geomorphology and Hydrology of Karst Terrains. New York. Oxford University Press. 464p.

White, W. B. \& Deike, G.H. (1989). Hydraulic geometry of caves passages. In: White, W.B. \& White, E.L. Karst Hydrology: concepts from Mammoth Cave area New York, Van Nostrand Reinhold. 1: 223-258.

Williams, P. W. (1971) - Illustrating morphometric analysis of karst with examples from New Guinea. Zeitschrift fur geomorphologie 15(1): 40-61.

Williams, P.W. (1972) - Morphometric analysis of poligonal karst in New Guinea. Geological Society of American Bulletin 83: 761-796.

Williams, P.W. (1983) - The role of the subcutaneous zone in karst hydrology. Journal of Hydrology, $61: 45-67$. 



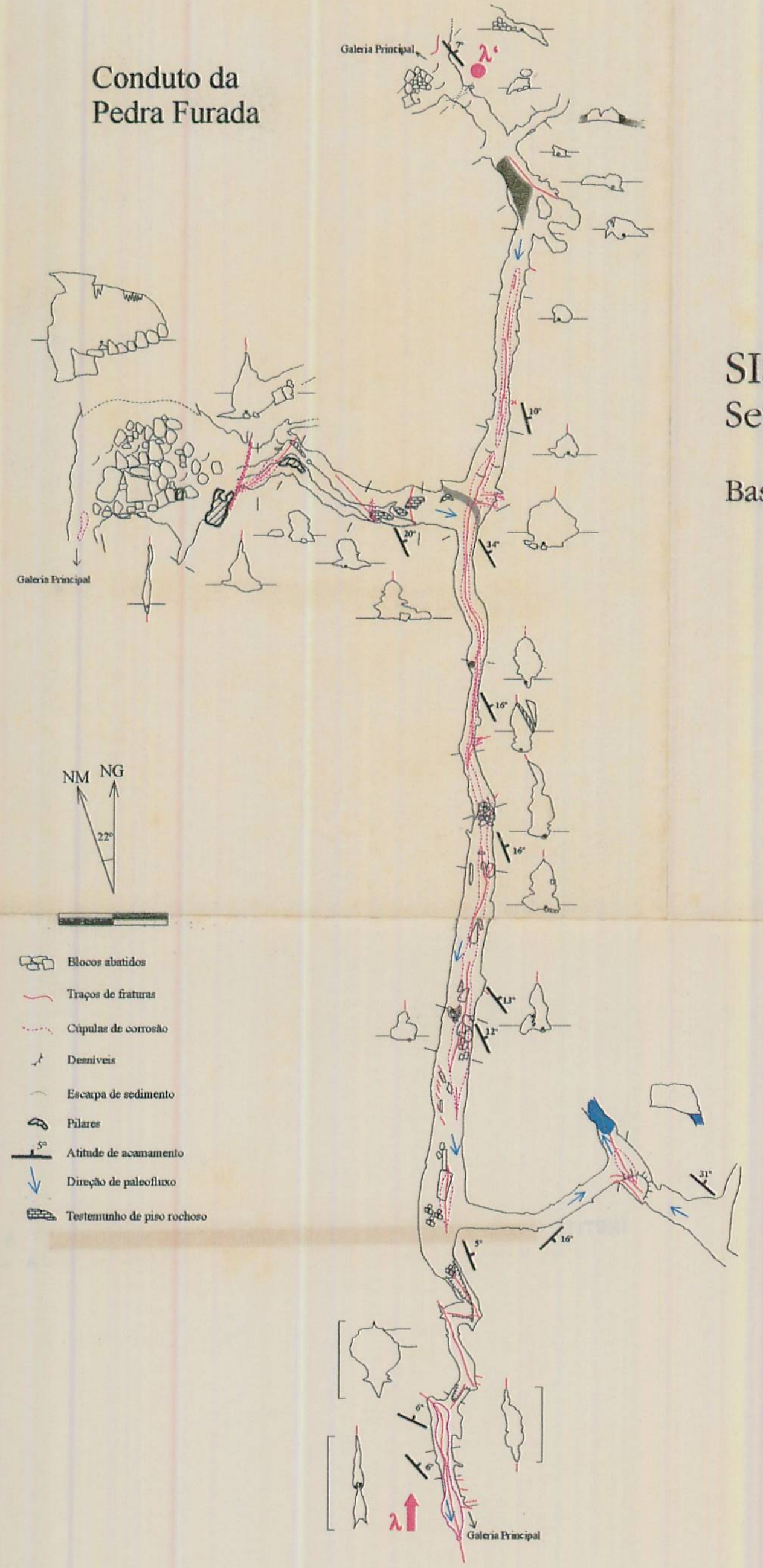

\section{SISTEMA da LAPA DOCE}

Setor 1 - Conduto da Pedra Furada (ANEXO 2)

Base cartográfica confecionada por:

Gabriela Slavecs (UPE)

Danilo Allegrini (UPE)

Ricardo Baroni (UPE)

A

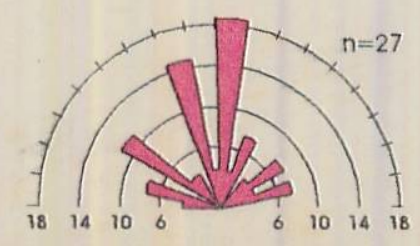

B

Orientação de condutos

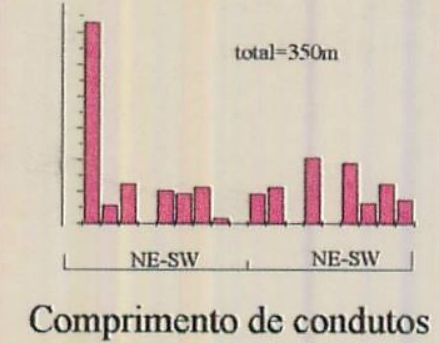

$\mathrm{C}$

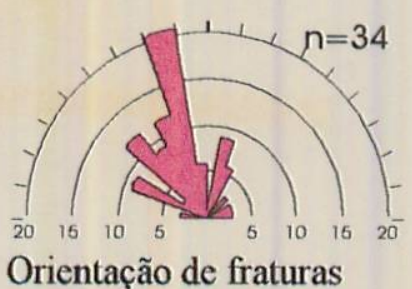

Orientação de fraturas

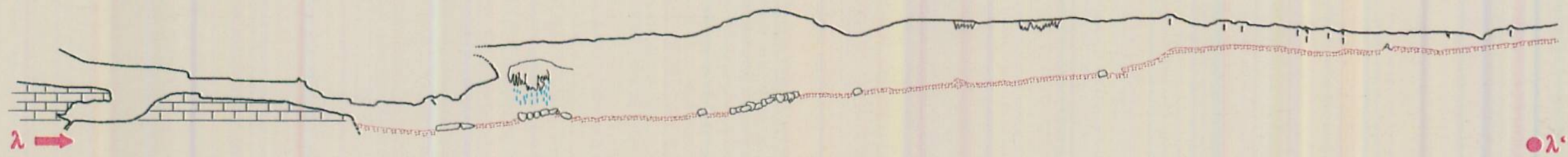




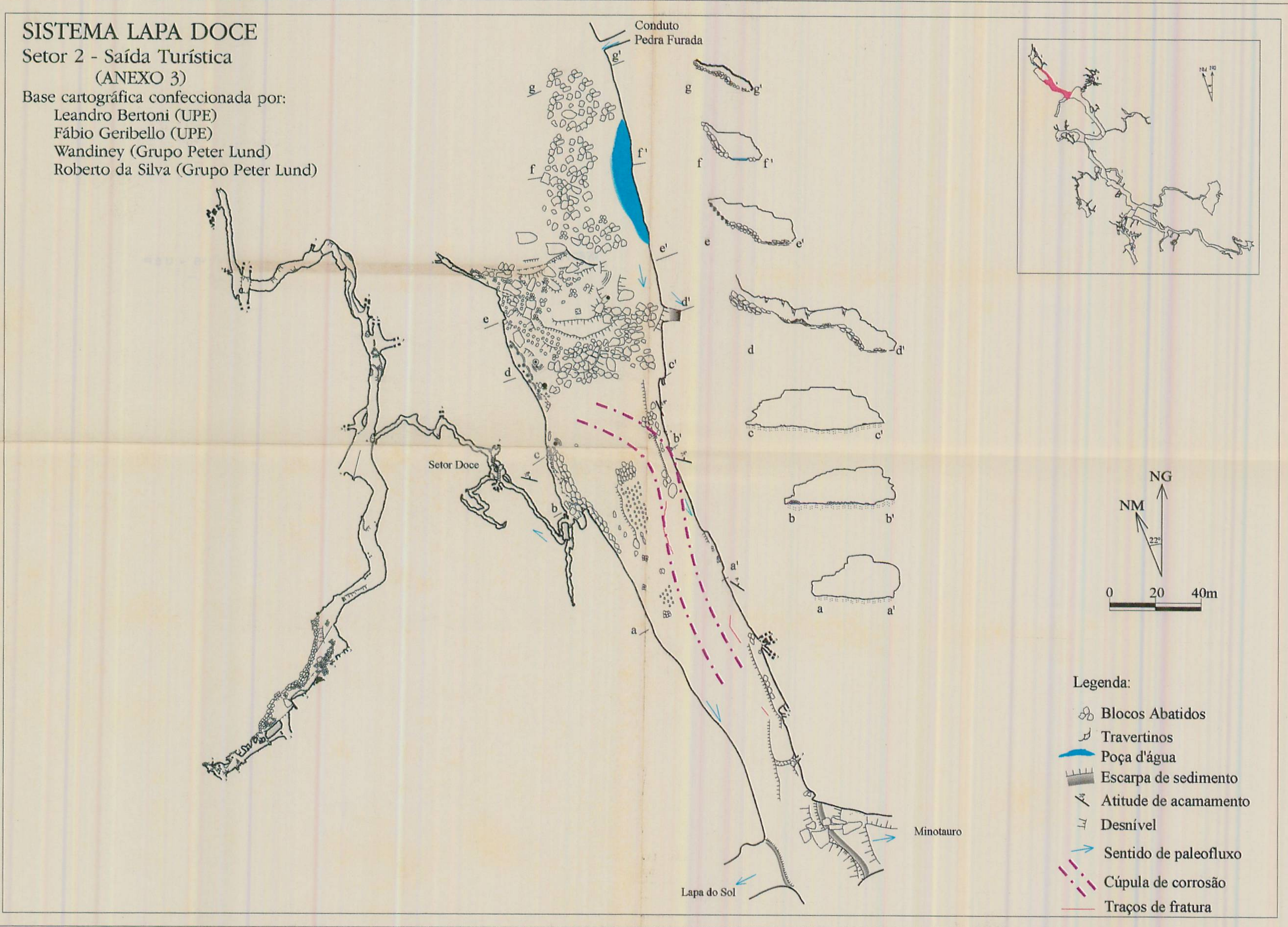




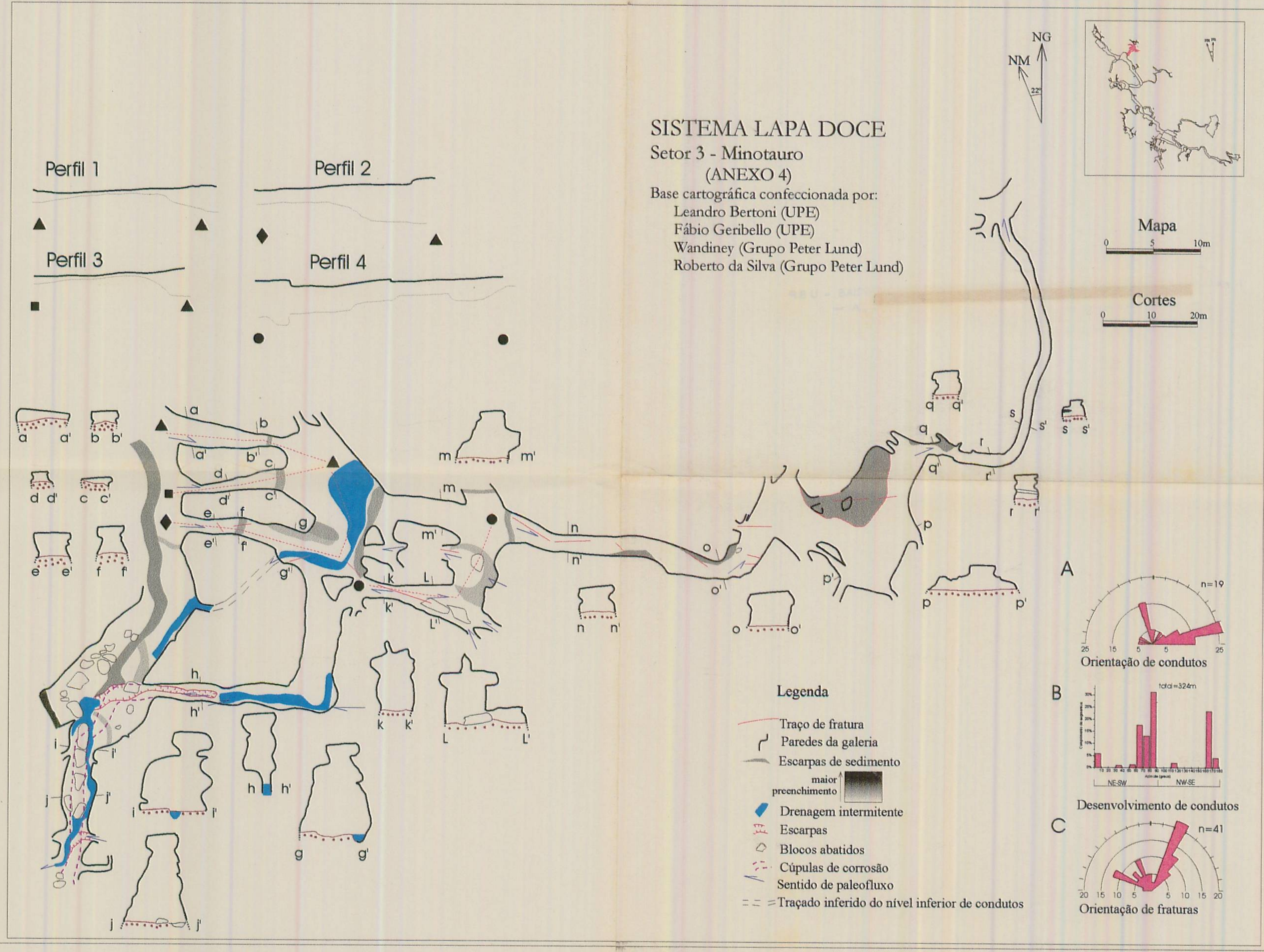

SISTEMA LAPA DOCE

Setor 3 - Minotauro Leandro Bertoni (UPE)

Fábio Geribello (UPE)

Wandiney (Grupo Peter Lund)

Roberto da Silva (Grupo Peter Lund)
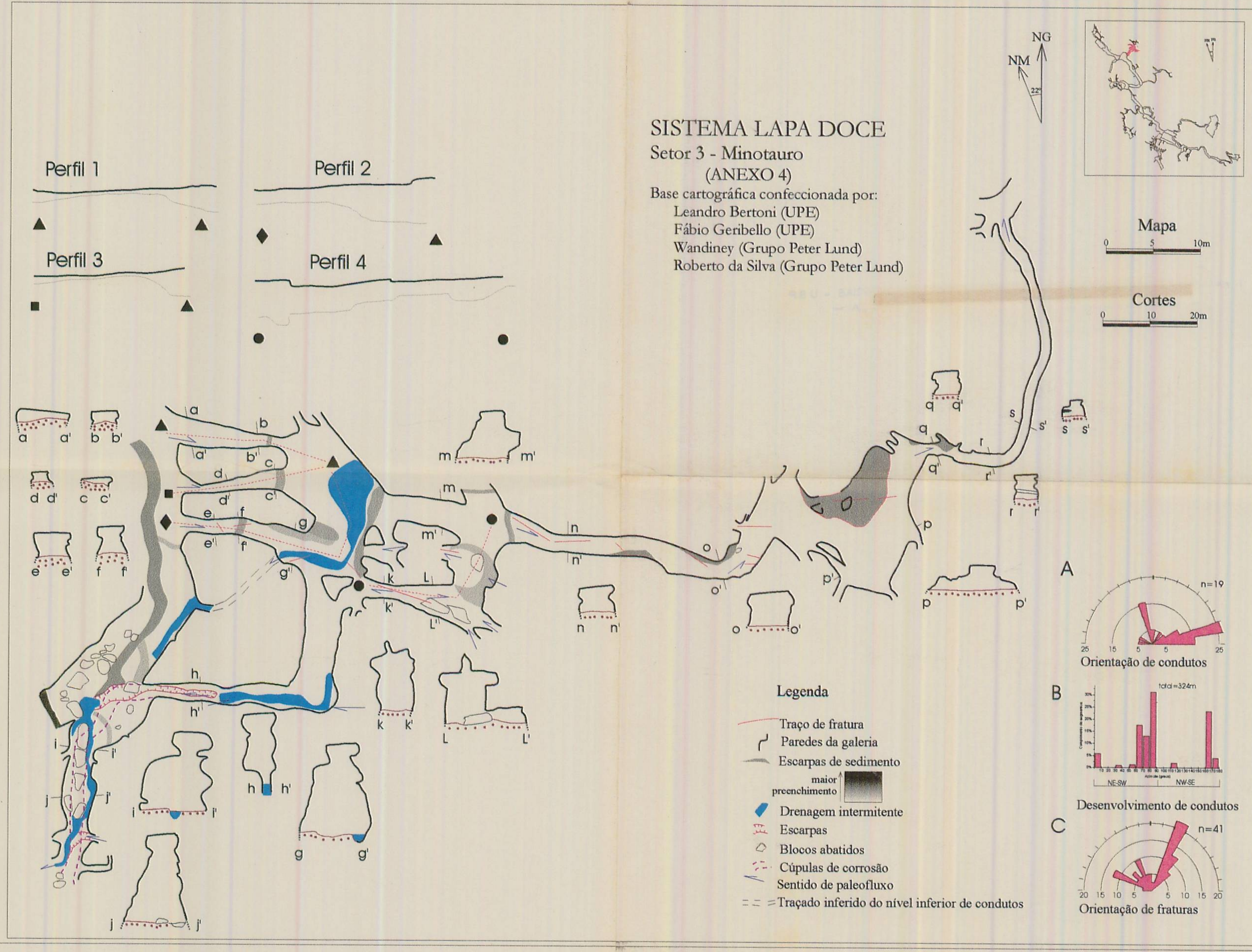


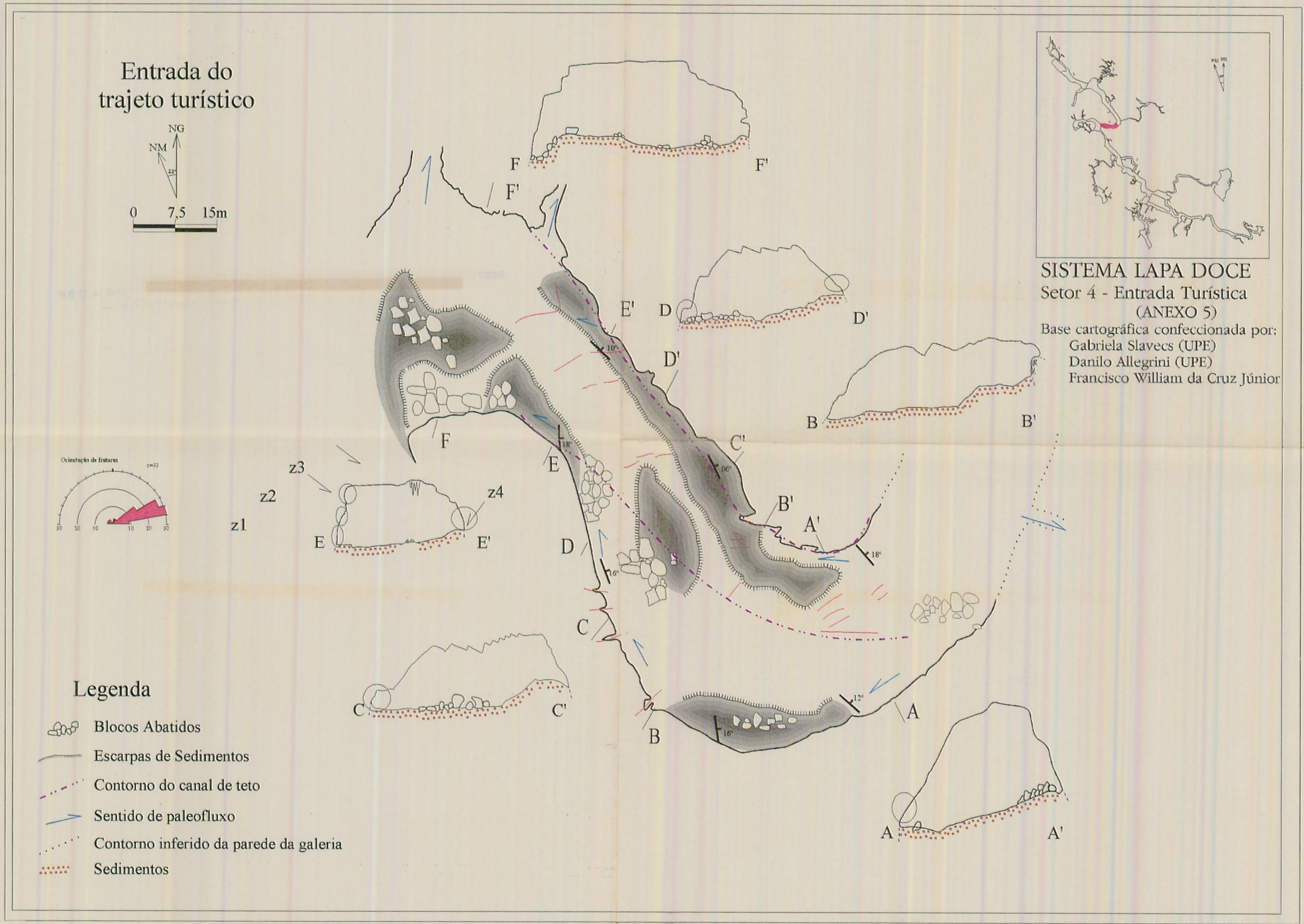




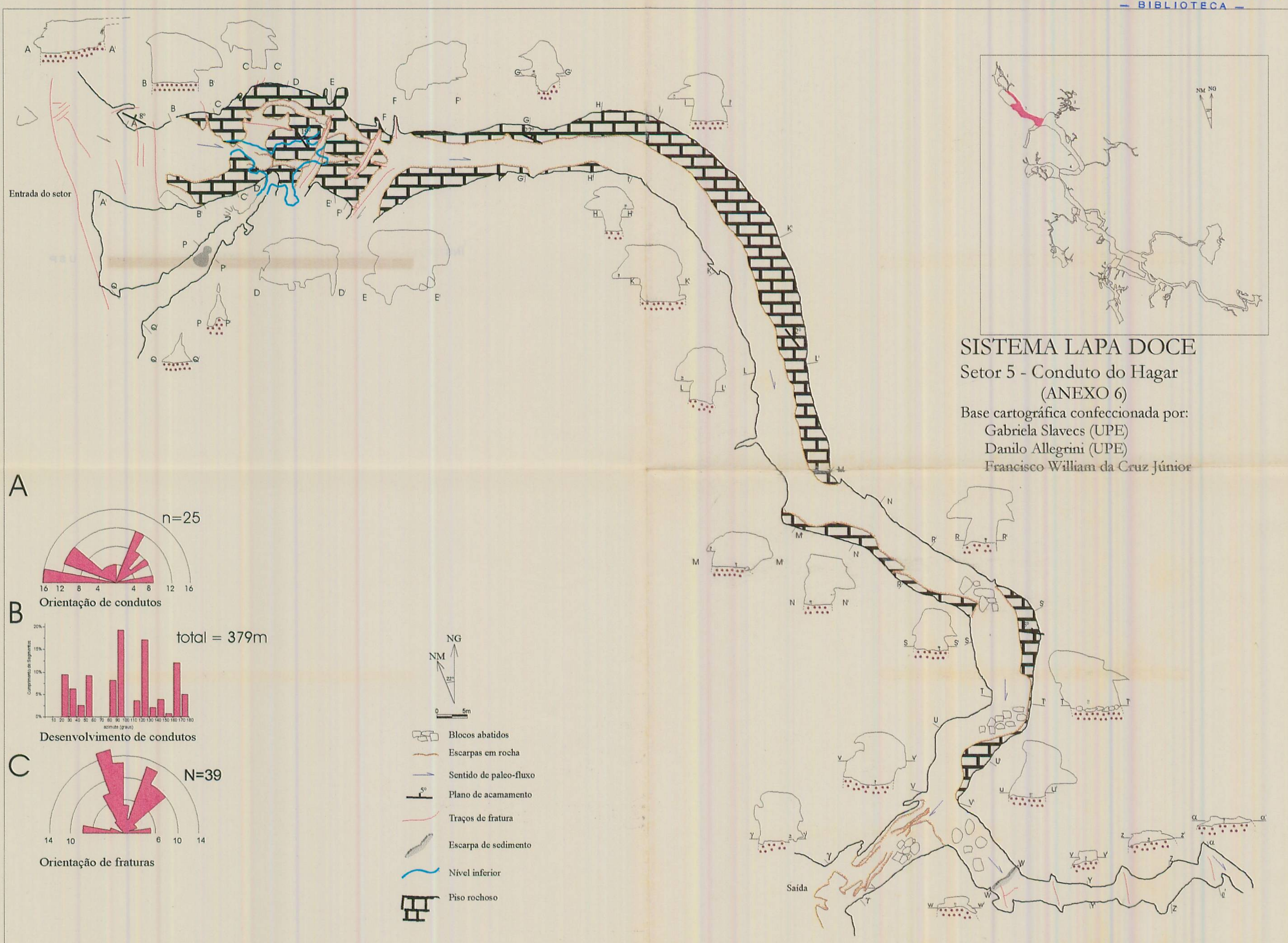



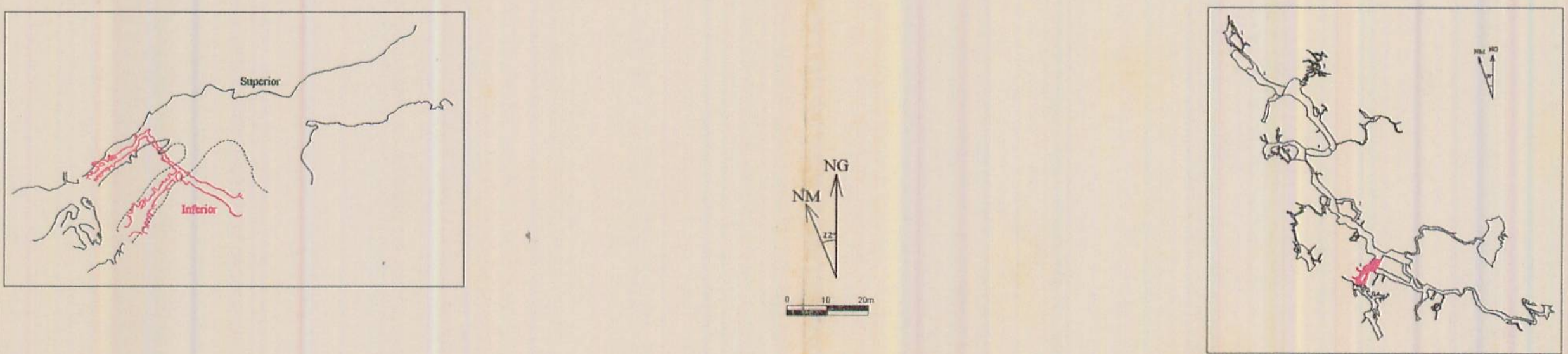

SISTEMA LAPA DOCE

Setor 6 - Conduto do Neguinho (ANEXO 7)

Base cartográfica confecionada por:

Gabriela Slavecs (UPE)

Danilo Allegrini (UPE)

Francisco William da Cruz Júnior
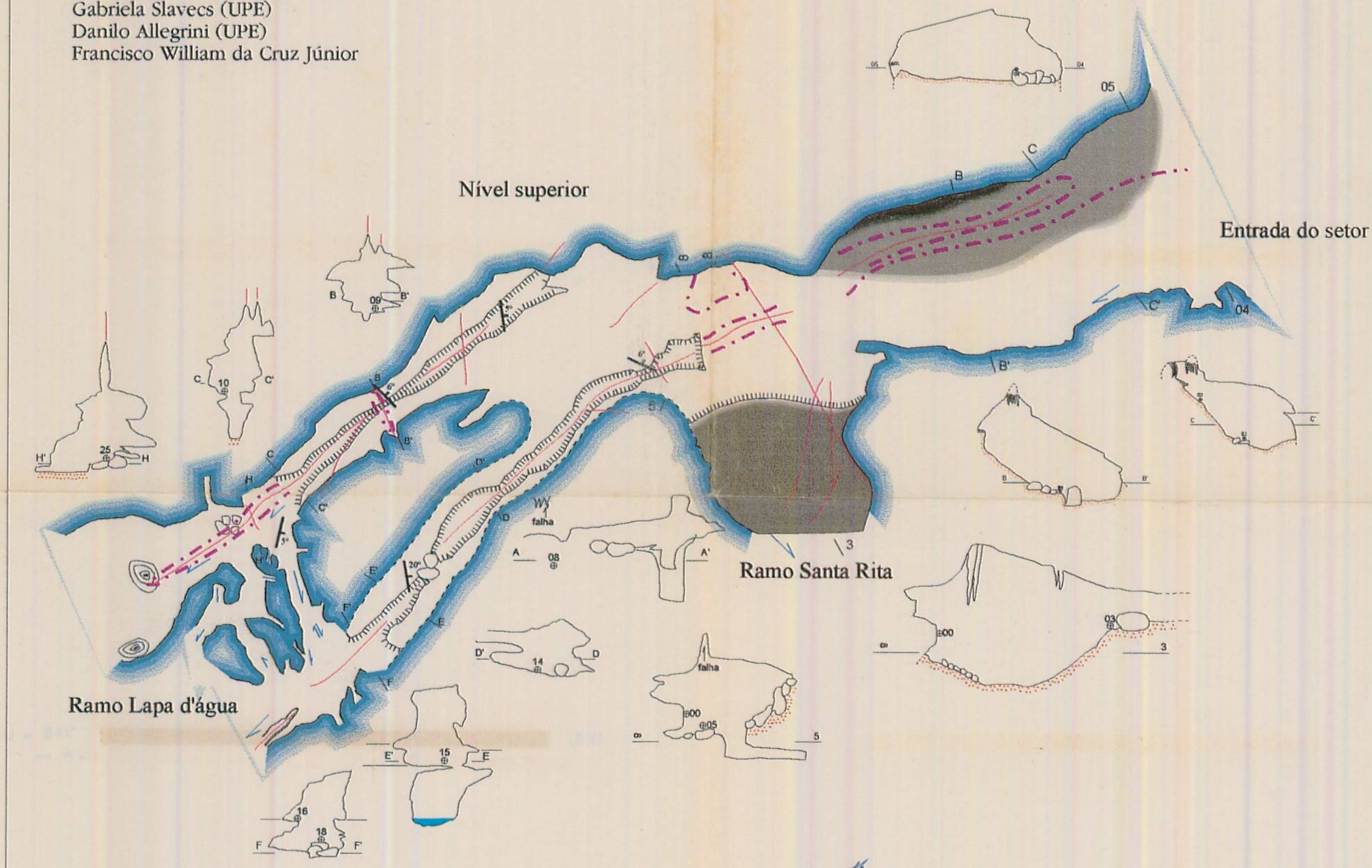
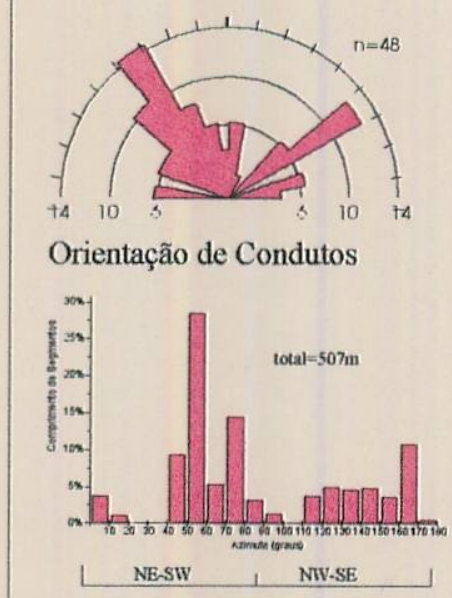

Desenvolvimento de Condutos

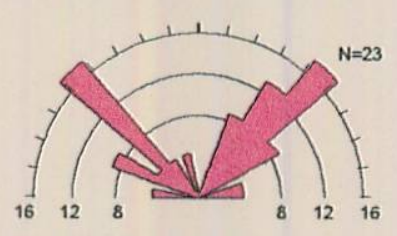

Orientação de Fraturas

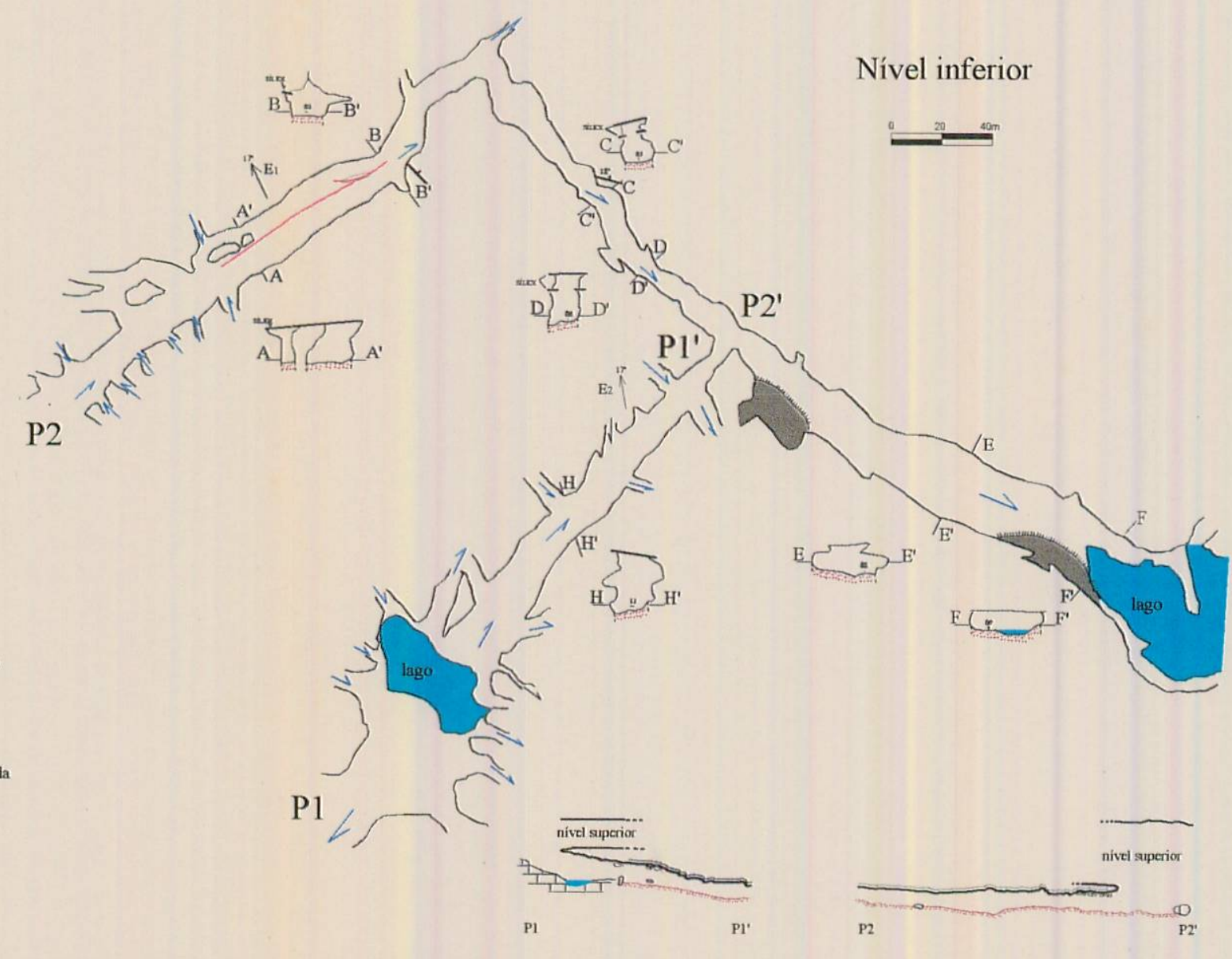




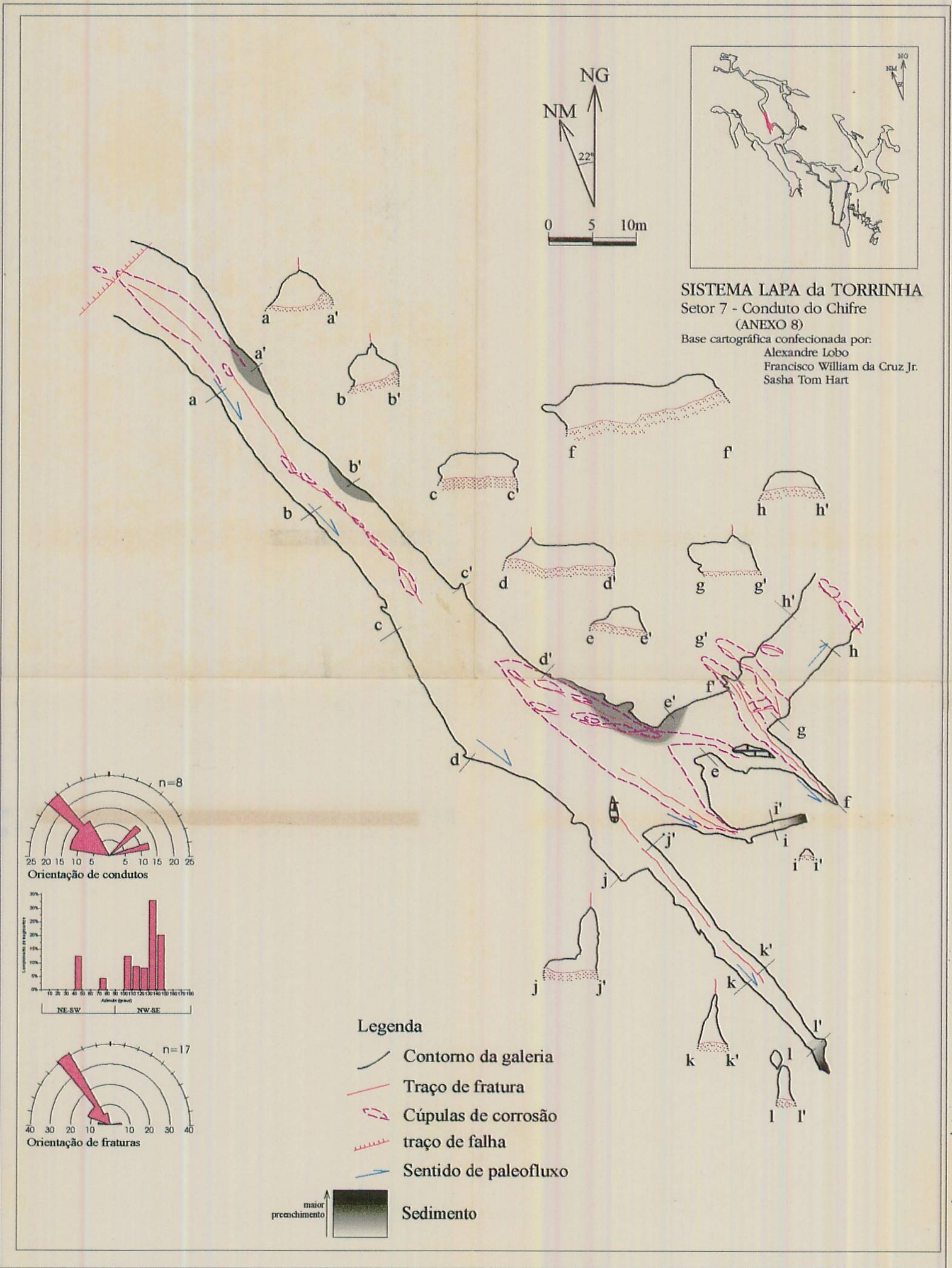




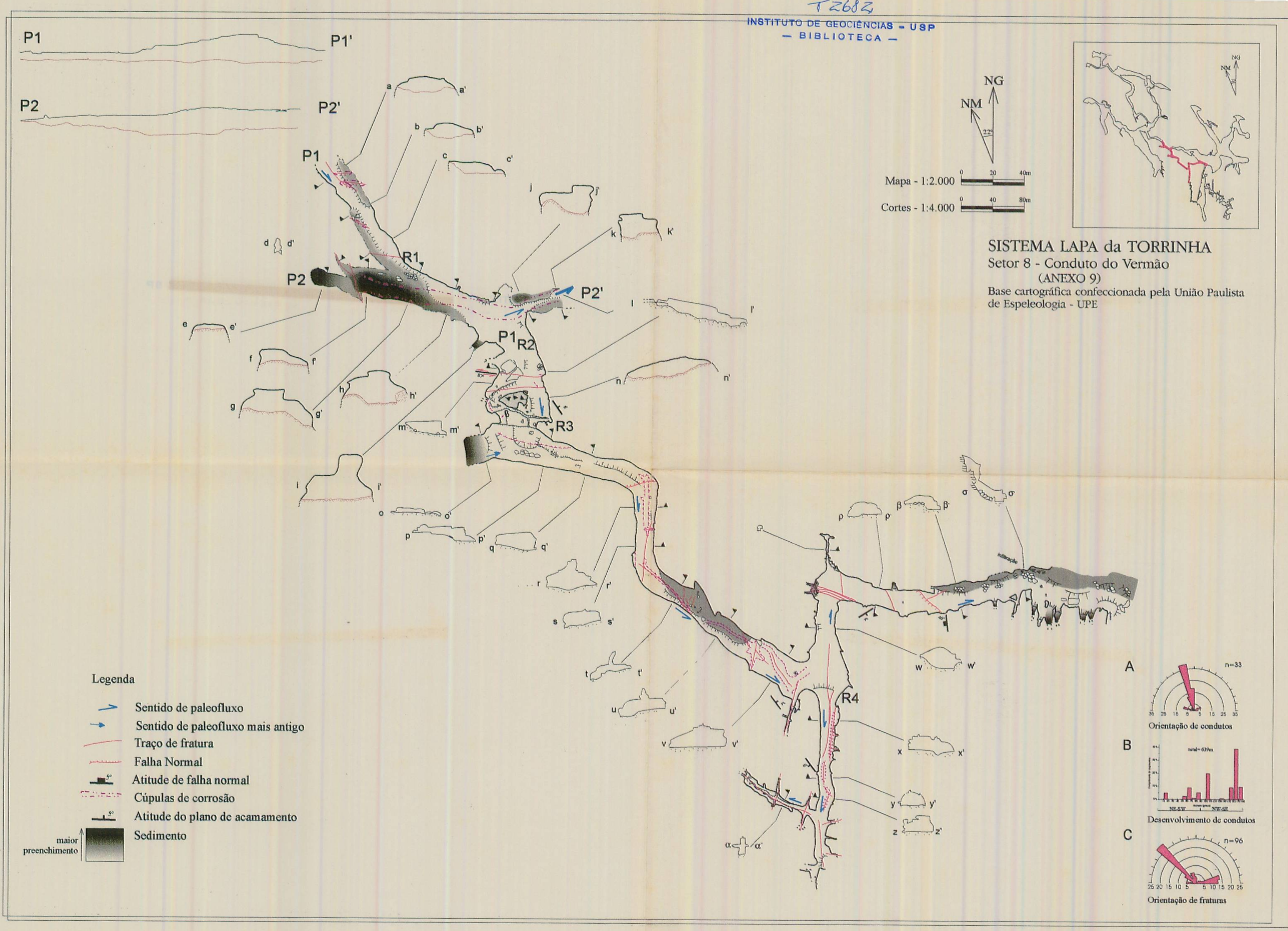




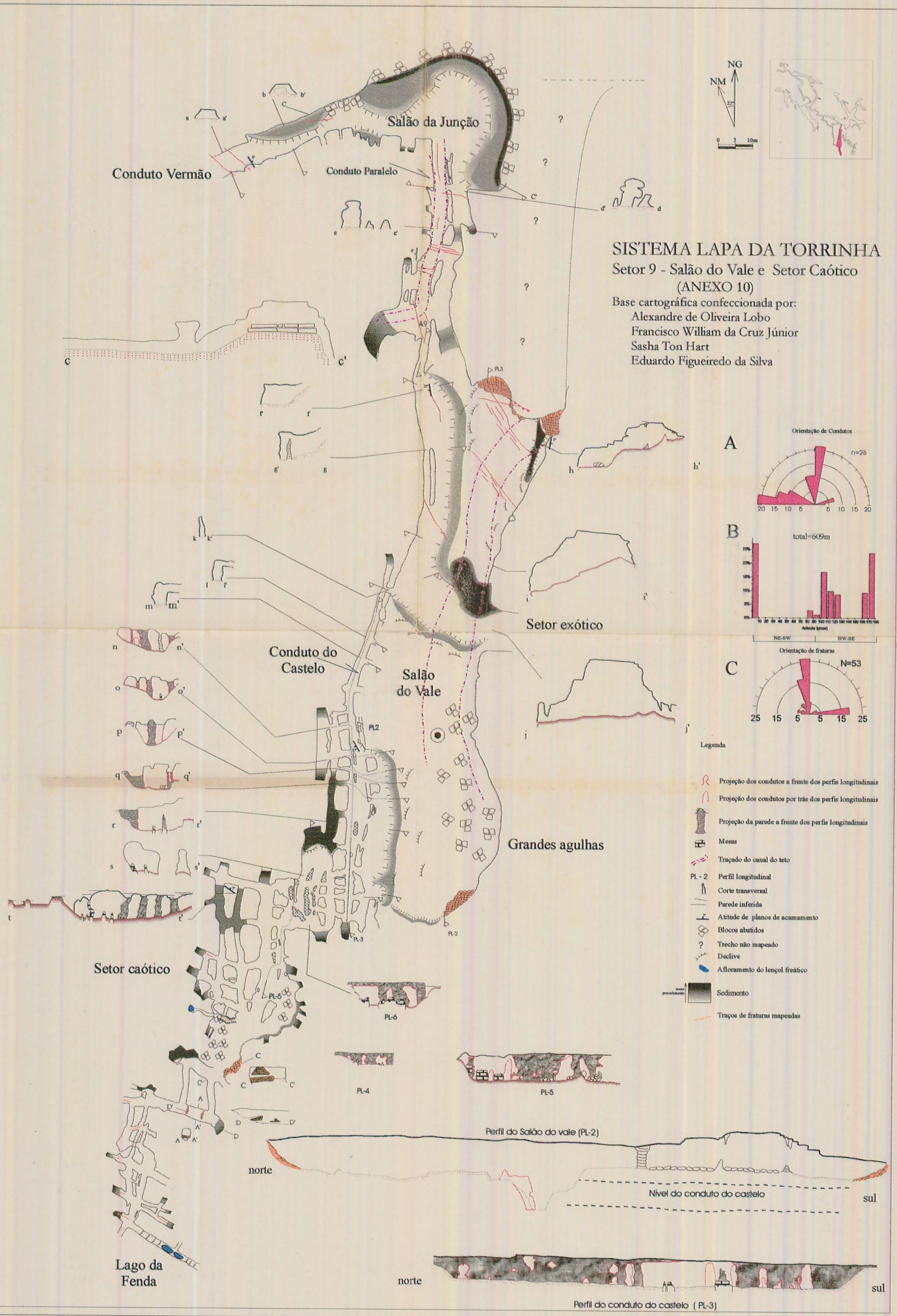

